Portland State University

PDXScholar

Dissertations and Theses

Dissertations and Theses

Spring 6-2-2015

\title{
The Floating Men: Portland and the Hobo Menace, 1890-1915
}

Marin Elizabeth Aurand

Portland State University

Follow this and additional works at: https://pdxscholar.library.pdx.edu/open_access_etds

Part of the Labor History Commons, and the Social History Commons Let us know how access to this document benefits you.

\section{Recommended Citation}

Aurand, Marin Elizabeth, "The Floating Men: Portland and the Hobo Menace, 1890-1915" (2015).

Dissertations and Theses. Paper 2400.

https://doi.org/10.15760/etd.2397

This Thesis is brought to you for free and open access. It has been accepted for inclusion in Dissertations and Theses by an authorized administrator of PDXScholar. For more information, please contact pdxscholar@pdx.edu. 
The Floating Men:

Portland and the Hobo Menace, 1890-1915

\section{by}

Marin Elizabeth Aurand

A thesis submitted in partial fulfillment of the requirements for the degree of

\section{Master of Arts}

in

History

Thesis Committee:

Katrine Barber, Chair

Tim Garrison

Patricia Schechter

Michael McGregor

Portland State University 2015 
(C) Marin Elizabeth Aurand 


\section{Abstract}

At the beginning of the twentieth century, transient laborers in Portland, Oregon faced marginalization and exploitation at the hands of the classes that relied on them for their own prosperity. Portland at this time was poised on the cusp of flourishing as a major population and industrial center of the American West. The industries that fueled the city's growth were dependent on cheap and mobile manual labor made available by the expansion of the nation's railroads. As the city prospered and grew, the elite of the city created and promoted an image of the city as an Eden of material abundance where industriousness and virtue would lead inevitably to prosperity.

There was no room in Portland's booster image for unemployed but otherwise able-bodied men, termed hobos. Their very existence challenged both the image of the city itself, and broader and deeper pillars of American identity. The response to the presence of this mobile, underemployed and largely white male labor class by Portland citizens and institutions was driven by, and in turn helped shape, competing mythologies of both the American West and American masculinity at a time when the country was struggling to define and redefine these constructs. Examining these floating men through their portrayal in popular culture, laws, and charitable efforts of the time exposes a deep anxiety about the notions of worth, gender, and American virtue. 
Dedicated to Tut, Allen, Jackie and Jane 


\section{Acknowledgements}

First and foremost, I am deeply indebted to my thesis advisor, Katrine Barber. I came to the History Department armed with an American Literature background, a good memory for Presidential trivia, and little else. During my years at Portland State, Katy taught me how to think like a historian. Her unwavering support, even after my surprise relocation to Montana, was crucial as I took an idea about hobos and forged it into this thesis. Courses and conversations I had with Professors Schechter and Garrison gave me the framework I needed to adequately examine this topic. This thesis is the culmination of a great deal of thought and scholarship on gender, class, and the mythology of marginalized peoples, topics that were really brought to life through the courses I took with these talented scholars.

During this process, I learned that a true friend is one that will listen to the minutia of itinerant labor history for years on end and still invite you places. To Sheila, Tina, Jessica, Candy, and Bose Rosely, thank you for putting up with me, my flashcards, and my historic asides. I am very lucky to know a group of such brilliant, insightful, and hilarious women. And, finally, this thesis would not be as good, and certainly not as carefully proofread, without my husband, Tut. Tut, thank you for following me on this grand adventure, for carrying me through seemingly endless coursework, exams, and edits, and never doubting for a second that I could do this. You are my strength. 


\section{Table of Contents}

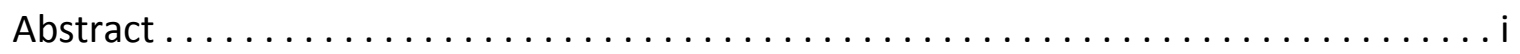

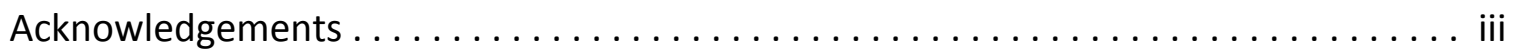

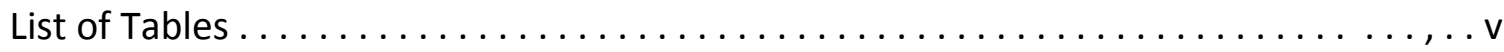

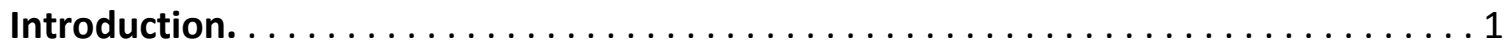

The Portland Hobo

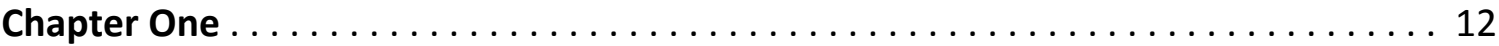

Creating a City and Defining its Character

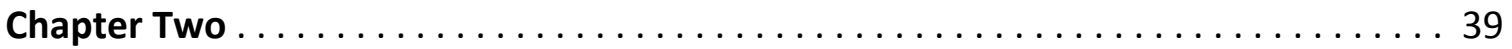

Charity for the Unworthy Poor: Portland Responds to the Tramp

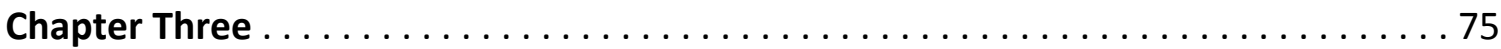

Portland Takes an Official Stance on the Hobo Menace

Chapter Four . . . . . . . . . . . . . . . . . . . . . . . . . . . . . . . 104

Transience in Popular Culture: Hobos Redefine the West

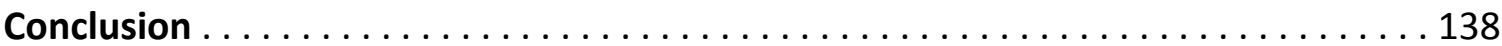

What can be done with the Floating Men?

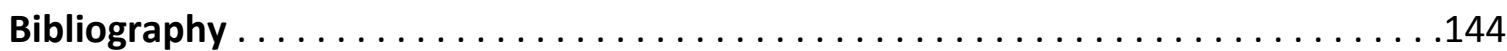




\section{List of Tables}

Table 1: Annual Board of Charities Report as Listed in the Oregonian . . . . . . . . 72 


\section{Introduction: The Portland Hobo}

When a coroner's jury sought the identity of a body found near Spokane Falls in the winter of 1890, one nearby resident testified that he had earlier taken the old man some food but did not know his name: 'I never learned it and never asked it. It is a peculiarity we have in this western country, to get acquainted with a man, talk to him, \& transact business with him, without asking for his name. $^{\prime 1}$

This unknown man in Spokane Falls was one of the many wandering laborers who flooded the Pacific Northwest at the turn of the century. They came to work in fields and lumber camps and when the season ended, they moved into cities throughout the country to avail themselves of the amenities of the urban slums. They were not members of any community except their own temporary work camp alliances. They left a mark on the cities they inhabited, but foremost as a collective nuisance, described nationwide as a menace, not as individual men. Their names were rarely recorded, their work was often undercompensated, and their deaths were unlikely to be mourned.

The men who made up this migratory labor force, especially those who suffered from frequent bouts of unemployment, were commonly referred to as hobos. This term was at first derogatory, then re-claimed to become honorable, and is now a quaint title that evokes a mythology of bindles and riding the rails with little or no grounding in its original meaning. The term hobo appeared in newspapers throughout the country in the 1870s. The origin of "hobo" is difficult to trace with any validity, but by 1890 the definition became fairly concrete. Hobos, according to contemporary accounts, were homeless men who were willing to work but did not have jobs. In 1896, the Oregonian

\footnotetext{
${ }^{1}$ Mark Wyman, Hoboes: Bindlestiffs, Fruit Tramps, and the Harvesting of the West, Kindle Edition (Hill and Wang, 2010), 1021.
} 
defined a hobo as "a tramp who begs, but will work rather than commit crime." Another contemporary source suggests "there are three types of the genus vagrant: . . . The hobo works and wanders, the tramp dreams and wanders, and the bum drinks and wanders." 3

The term "tramping," which was linked to hobo culture, was considered a pathology. Believed to date to the Civil War, tramps were soldiers who were unable or unwilling to give up a lifestyle of wandering after the war. Over time, the image of the wandering American male became conflated into a single reactionary symbol, not against the horrors of the Civil War, but the horrors of industrialization, the removal of the man from family and community as the provider, and the sweeping move toward wage labor rather than self-sufficiency. ${ }^{4}$ By the second decade of the twentieth century, the hobo image became a duality; transgressor and hero, the inferior male who could not conform to a new America and a counterculture icon, challenging staid societal expectations. Unlike vagrant populations in previous decades, mobility defined the tramps and hobos at the turn of the century. The advent of widespread rail transport and the need for seasonal labor in the newly opened West created a new kind of underclass. While the term hobo itself has a derogatory connotation, it also allowed for a useful distinction between the sedentary laboring classes of previous decades and the transient laborer, a distinction that would dictate the treatment of these men within urban boundaries.

\footnotetext{
2 "Notes and Comment" Oregonian November 14, 1896, 4.

${ }^{3}$ Wyman, Hoboes. 673.

${ }^{4}$ Tim Cresswell, The Tramp in America, Kindle Edition (Reaktion Books Ltd, 2001), 2206.
} 
As the hobo image was created, Portland, Oregon was on the rise in both population and economic power. In preparation for the city's elevation, Portland's elite created a narrative that defined Portland as a beacon of economic growth, cultural sophistication, and material abundance. This image echoed a frontier mythology that permeated scholarly works, booster literature, and public conceptions: the idea that the strongest men travelled West, that success was given freely to those who worked for it, and that the West would be won through settlement. However, as Portlanders adopted this identity, the growth of transient labor created a narrative antithesis within the city. This temporary labor force was necessary to sustain Portland's wealth but operated outside of the Portland mythology.

Roaming male populations were a tangible component of a new wage labor system, a movement away from self-sufficiency and a personification of the diminished role of home and family. ${ }^{5}$ Examining Portland's response to transient labor, through laws, charitable efforts, and popular culture, creates a counter narrative to the early twentieth century notion that Portland was the culmination of the promise of the American West. It is clear that the city's elites developed methods to diminish or systematically dismiss the hardships that faced the transient labor force while simultaneously relying on this force to create the abundance that the city depended on and celebrated.

\footnotetext{
${ }^{5}$ Dmitri Palmateer, “Charity and the 'Tramp': Itinerancy, Unemployment, and Municipal Government from Coxey to the Unemployed League," Oregon Historical Quarterly 107, no. 2 (July 1, 2006): 228-53. 230.
} 
The hobo menace in Portland encompasses two scholarly areas: the importance of myth in the American narrative, and issues of masculinity in the American West. New Western history, as popularized in the work of Patricia Limerick and others, acknowledged that the prevailing notion of the American West, one that harkened back to Frederick Jackson Turner's "The Significance of the Frontier in American History," ignored a more complex historic narrative and systematically excluded women, minorities, indigenous peoples, and transgressive populations from western history. Since the publication of Limerick's Legacy of Conquest in 1987, historians have worked to fill in these gaps, challenge the east-to-west narrative of Western American history, and place marginalized populations into focus. As the Turner thesis's savage-tocivilization approach to Western history was dismantled, historians also began to examine the power and pervasion of the Western mythology as a defining force in American identity. An examination of the importance of the mythology began with Henry Nash Smith's Virgin Land: The American West as Symbol and Myth (1950) and continues to the present day with works like Richard Slotkin's Gunfighter Nation (1992), Richard White's "It's Your Misfortune and None of my Own": A History of the American West (1991) and David Wrobel's Promised Lands (2011), among others.

Examining the importance of mythmaking bridges scholarship in history and literary theory, allowing fiction to act as a representation of a place in time, as represented in Henry Nash Smith's examination of the dime novel West. The Western narrative was built in the space between fiction and reality, with both the actual and idealized West forming in tandem. Louis Warren's Buffalo Bill's America: William Cody 
and the Wild West Show (2006) is one of the more recent works that identifies the importance of myth not only to recollections about the West, but also to how Westerners themselves related to one another. In the broader sense, fiction and myth have the power not only to define the American West, but also to define such intangibles as masculine identity. Henry Nash Smith's work on the dime novel male, while at times outdated, is one key example of the concept of the male identity forming through literature. More recent historians in masculine identity suggest that literature is both a reflection and a catalyst for changing conceptions of masculinity, with actual men modeling themselves after their fictionalized counterparts.

Questions of gender in the American West have only recently expanded to include work on masculine, homosexual, and transgendered experiences. Modeled after feminist theory on gender, masculine studies were long ignored in Western history, as the white male experience was well documented in historical works. However, current scholarship allows for the belief that, like a feminine identity, masculinity is largely constructed rather than innate. Christine Di Stefano's article “Who the Heck Are We? Theoretical Turns against Gender" published in 1991 is an early example of opening gender history to include men. Western historians have taken note of this push to analyze the male experience, not as a default American identity, but as a complex gendered relationship to the world.

The most successful of these studies is Susan Johnson's Roaring Camp: the Social World of the California Gold Rush (2000), in which Johnson examines how maledominated environments impact relationships and the importance of homosocial bonds 
in the American West. Adding to the conversation is Peter Boag's study of both homosexual and transgendered history in the American West in Same-Sex Affairs: Constructing and Controlling Homosexuality in the Pacific Northwest (2003), and ReDressing America's Frontier Past (2011). The compilation of essays Across the Great Divide: Cultures of Manhood in the American West (2001) edited by Michael Basso includes focused scholarship on many branches of Western masculine spheres, from public hangings to ranches, examining how these experiences defined America's understanding of what a man should and should not be. These essays gave me a framework by which to examine hobo masculinity.

Gender scholarship, such as E. Anthony Rotundo's work on American masculinity, was key in my analysis of passionate manhood, a movement towards corporeal and rugged masculinity, which illuminated the broad social context in which transient males lived and were observed. ${ }^{6}$ While some of these works touch on labor and masculinity, unemployed populations in the American West have not been examined through the lens of gender, despite the interesting issues regarding gender among men that were dependent on aid. In an era in which his profession and place in society defined a man, the itinerant laborer remains hard to classify.

Serious work related to the hobo at the turn of the century has only recently separated itself from popular culture conceptions and tall tales. My work regarding

\footnotetext{
${ }^{6}$ E. Anthony Rotundo, American Manhood: Transformations In Masculinity From The Revolution To The Modern Era, Reprint edition (New York: Basic Books, 1994).
} 
hobo culture draws heavily on the work of Tim Cresswell and Todd DePastino. ${ }^{7}$ Tim Cresswell was instrumental in my understanding of the hobo mythology and the privilege of personhood in relation to itinerant male populations. While Cresswell's work is well researched, his scope necessitated broad generalizations regarding the transient experience. Peter Boag's work on same sex vice scandal of 1912 provides valuable background on the North End district and the transient male culture in Portland as well as issues of homosexual and homosocial relationships at the turn of the century. ${ }^{8}$ Boag's focus, however, is on the gay experience, which, while a part of the hobo identity, was not all-inclusive. In addition, John D. Seeyle offered one of the only analyses of the hobo mythology and an especially useful comparison to the frontier mythology. While I do not agree with his conclusions, Seeyle's work helped shape the structure of my argument in Chapter $4 .^{9}$

Mark Wyman's Hoboes: Bindlestiffs, Fruit Tramps, and the Harvesting of the West (2010) which focused on migratory laborers in the fields of the Pacific Northwest and Carlos Schwantes's "Images of the Wageworkers' Frontier" (1988) provided background for the world of the unskilled laborers when they were not in Portland. ${ }^{10}$ For a detailed analysis of census data, I relied on Chris Sawyer's dissertation, "From Whitechapel to Old Town: The Life and Death of the Skid Row District, Portland,

\footnotetext{
${ }^{7}$ Cresswell, The Tramp in America. Todd DePastino, Citizen Hobo: How a Century of Homelessness Shaped America (Chicago: University of Chicago Press, 2003).

${ }^{8}$ Peter Boag, Re-Dressing America's Frontier Past, Kindle Edition (Berkeley: University of California Press, 2011).

9 John D. Seelye, "The American Tramp: A Version of the Picaresque," American Quarterly 15, no. 4 (December 1, 1963): 535-53.

${ }^{10}$ Wyman, Hoboes. Carlos A. Schwantes, "Images of the Wageworkers' Frontier," Montana: The Magazine of Western History 38, no. 4 (October 1, 1988): 38-49
} 
Oregon" (1985). Kimbark MacColl's look at the business class of Portland in both Merchants, Money \& Power : the Portland Establishment, 1843-1913 (1988), and The Shaping of a City: Business and Politics in Portland, Oregon, 1885-1915 (1976) was extremely helpful for examining the economic and social environment at the time and the impact of elite classes of policy decisions within the city. ${ }^{11}$ To understand the changing conceptions of charity at the turn of the century, I relied on the works of John T. Cumbler, Laylon Wayne Jordan, Kenneth Kusmer, Amy Stanley, and Dmitri Palmateer. ${ }^{12}$

Unfortunately, primary documentation created by transient laborers is limited, so instead I focused my original research on Portland's response to the transient laborer, rather than the transient laborer's response to Portland. I limited my scope to the primary sources of Portland's economic elite, namely the City Board of Charities records, funded through the charitable donations of the richest families in the city, and the Oregonian, a newspaper that held its appeal with the business class. The City Board of Charities records at the Oregon State Archives includes promotional materials,

\footnotetext{
${ }^{11}$ E. Kimbark MacColl, The Shaping of a City: Business and Politics in Portland, Oregon, 1885-1915 (Georgian Press Co, 1976). Chris D Sawyer, "From Whitechapel to Old Town: The Life and Death of the Skid Row District, Portland, Oregon," 1985.

12 John T. Cumbler, "The Politics of Charity: Gender and Class in Late 19th Century Charity Policy," Journal of Social History 14, no. 1 (October 1, 1980): 99-111. Laylon Wayne Jordan, "The Method of Modern Charity': The Associated Charities Society of Charleston, 1888-1920," The South Carolina Historical Magazine 88, no. 1 (January 1, 1987): 34-47. Kenneth L. Kusmer, "The Functions of Organized Charity in the Progressive Era: Chicago as a Case Study," The Journal of American History 60, no. 3 (December 1, 1973): 657-78. Amy Dru Stanley, "Beggars Can't Be Choosers: Compulsion and Contract in Postbellum America," The Journal of American History 78, no. 4 (March 1, 1992): 1265-93. Palmateer, "Charity and the 'Tramp.'”
} 
correspondence, and records regarding aid given. ${ }^{13}$ These records on migrant labor revealed the establishment's views, attitudes, and actions toward floating populations. The Oregonian, digitally available and searchable through the Multnomah County Library, had over 1,000 articles with the keywords "hobo," "tramp," and "City Board of Charities" between 1890 and 1915, which were analyzed for broad themes as well as specific examples of Portland's reaction to the hobo.

In this thesis, there are many issues of transient populations that go unaddressed or only briefly mentioned, chiefly the impact of labor movements and subsequent legislation on the transient male population. The labor movement and its achievements are broadly significant to the history of unskilled laborers, but are tangential to upper class Portland's direct response to the transient male. These issues are of such complexity they would be inadequately addressed only in part and are already well covered by existing literature. In addition, the hobo population is not confined to one city or state. Issues related to the tramping classes were not unique to the Pacific Northwest, but each city's treatment of itinerant laborers is so nuanced that drawing large comparisons between Portland and other cities would only create oversimplification of a complex issue.

Finally, the struggle between the idealized view of one city and the treatment of contradicting elements does not begin in 1890 and disappear in 1915, the years that bracket my work, but remains an ongoing struggle of which the hobo menace is only

\footnotetext{
${ }^{13}$ Board of Charities/Associated Charities Correspondence 1889-1914, Public Welfare Commission, State of Oregon Archives, Salem, Oregon.
} 
one example. However, this time frame does allow me to examine multiple issues that were not apparent in previous decades. First, this is the era in which Portland rose to prominence as a Western metropolis in terms of wealth, which more clearly defined the elite upper class of the city. Second, the newly expanded rail system allowed for easy migration to the area, expanding the unskilled migratory labor force. Third, the population growth during this period created an urge among Portlanders to have a unifying identity, one largely defined in booster literature and perpetuated by elites at the expense of the unskilled laborer. And finally, a crisis in masculine identity instigated by a movement towards a wage labor system manifested itself in the treatment of the hobo class at the turn of the century.

Chapter One examines the history of Portland, focusing on the importance of identity as a city of abundance, and provides an overview of itinerant labor in the Pacific Northwest. This chapter outlines how transient males presented a challenge to Portland's city of abundance identity, which in turn impacted how those men were treated. Chapter Two focuses on the charitable response to the hobo by the City Board of Charities. The City Board of Charities used the definition of the "able bodied man" as a tool to ignore migrant laborers when dealing with the city's poor and maintain an image of city-wide wealth. Chapter Three will examine the laws surrounding vagrancy and the treatment of unemployed laborers upon their arrest. Like charitable organizations, the treatment of arrested transient men reflected the biases of Portland's elites, aiming to ignore or remove homeless populations rather than elevate them. Chapter Four will look at the hobo in popular media, tracing the creation of the hobo 
archetype and how that archetype manifested itself in the Portland elite scene. While the charitable and official relationship to the hobo focused on removal and diminishment, popular culture references to the hobo alternated between distain and near-reverence, creating a mythologized hobo who became part of the Western narrative, despite the poor treatment of itinerant laborers in the city itself. The hobo in Portland was ignored, imprisoned, or sent away, while the hobo mythology became canon in theatres throughout the city. It is this contradiction that most accurately underscores the position of the transient male in the Pacific Northwest during this period. He appeared first as a necessary evil, then a threat to civilized society, and finally a strange postscript to the Western American mythology. 


\section{Chapter One \\ Creating a City and Defining its Character}

Portland was a place of dynamic change during the period leading into the twentieth century. While already an important city in Oregon, this period sees Portland competing on a national and global stage, establishing itself not only as a city of commerce and industry, but as a city set to rival established East Coast urban centers. As Portland elites led booster campaigns, touting Portland as the conservative alternative to the rowdy Western rush cities like Seattle and San Francisco, they also willfully ignored the migrant laboring classes upon which the majority of Portland's wealth was built. Portland's relationship to this new facet of labor depended on a conservative identity rooted in a pioneer past and an industrial economy that relied on a rural hinterland and necessitated a mobile unskilled workforce. It is at this intersection, where the fictions of Portland's booster idealism met the realities of a floating labor class, that one can analyze issues of class, masculinity, charity, and myth at the turn of the century.

\section{Portland Booms}

In the 1850 U.S. Census, Portland had a population of 821 . Of those, 75 percent were native born and 12 percent of the entire population came from just two states, New York and Massachusetts. Half of the residents counted in 1850 had arrived to 
Portland that year, and the majority were younger than $30 .{ }^{1}$ From these humble beginnings, Portland grew to be one of the most prosperous cities in the American West in only a few decades, weathering boom and bust cycles while continuing to grow in size, population, and finances. By the 1870 's, Portland became a thriving metropolitan center, connecting resource extraction industries with trade routes, and led the Pacific Northwest in economic prosperity. Among those 800 early settlers, a merchant class developed, and then a millionaire class, whose thoughts on the city and its future would come to define the next decades.

In 1890, Portland's population continued to surge and its commercial growth catapulted the city into a major financial and industrial powerhouse. ${ }^{2}$ An economic boom that began in 1887 and continued to the Depression of 1893 punctuated this growth. ${ }^{3}$ In the period between 1896 and 1898, more than 300 new businesses formed in Oregon and 136 of those were related specifically to extractive industries. ${ }^{4}$ The businesses operating in Portland depended on the hinterland surrounding Multnomah County and beyond to thrive. Timber harvesting at the turn of the century was centered on the Willamette Valley and eastern Cascades, farms were in the Willamette Valley and along the Columbia River, while orchards were in Hood River, Yamhill and Marion

\footnotetext{
${ }^{1}$ E. Kimbark MacColl and Harry H. Stein, "The Economic Power of Portland's Early Merchants, 1851-1861," Oregon Historical Quarterly 89, no. 2 (July 1, 1988): 119.

2 Sawyer, "From Whitechapel to Old Town." 120.

${ }^{3}$ E. Kimbark MacColl, Merchants, Money \& Power : The Portland Establishment, 1843- 1913 / E. Kimbark MacColl with Harry H. Stein, First Edition (Georgian Press, 1988). 261.

${ }^{4}$ MacColl, The Shaping of a City. 215.
} 
counties. ${ }^{5}$ River transportation and then the expanding rail system linked these regions to the city of Portland, which became a major player in the export of Oregon goods.

Growth was not significantly slowed by the depression, and the period between 1890-1900 ranked Portland's growth rate as the third fastest of all major American cities due in part to the consolidation of East Portland and Albina on July $6,1891{ }^{6}$ Consolidation also moved the center of growth to east of the Willamette River, which surged in population, increasing fivefold from $1905-1910 .^{7}$ This growth necessitated the advent of street railways that connected distant neighborhoods to the city center, allowing residential areas to grow, while the urban center took on a primarily commercial orientation. ${ }^{8}$ By 1909 , the Mount Tabor and East $92^{\text {nd }}$ neighborhood joined Portland through consolidation and Portland ranked third in population of cities west of Omaha, outnumbered only by San Francisco and Denver. ${ }^{9}$

In addition to growth in land and population, the years following the Lewis and Clark Centennial Exposition in 1905, an event showcasing the natural resources of the Pacific Northwest and the potential in global trade markets, also saw low rates of unemployment and an immense building boom. ${ }^{10}$ In 1910 alone, Portlanders spent over twenty million on new construction, and with new construction came population

\footnotetext{
${ }^{5}$ William G. Loy, Atlas of Oregon, 2nd Ed, 2 Revised edition (Eugene, Or: Oregon State University Press, 2001). 92, 94, 9

${ }^{6}$ MacColl, Merchants, Money \& Power. 283, 336

${ }^{7}$ Ibid. 382

${ }^{8}$ MacColl, The Shaping of a City. 111; Randall V. Mills, "Early Electric Interurbans in Oregon: I. Forming the Portland Railway, Light and Power System," Oregon Historical Quarterly 44, no. 1 (March 1, 1943): 82104. 82.

${ }^{9}$ MacColl, The Shaping of a City. 121; MacColl, Merchants, Money \& Power. 288.

${ }^{10}$ Carl Abbott, "Greater Portland: Experiments with Professional Planning, 1905-1925," The Pacific Northwest Quarterly 76, no. 1 (January 1, 1985): 12-21. 13.
} 
surges. ${ }^{11}$ In 1905, the population of Portland was 110,929. By 1910 it had increased to 207,214, very nearly doubling in size. ${ }^{12}$ Historian Carl Abbott described the period following 1905 as "the greatest economic boom that Portland has ever experienced." ${ }^{13}$ The wealthy of Portland relished this era, cashing in on new industry and explosive growth to solidify their empires.

Portland's population boom coincided with the advent of railroads in the area, which allowed the easier movement of goods and people throughout the Pacific Northwest. The era of rail construction in the Portland area began with the chartering of the Oregon Central in 1866 and the Oregon and California Company in $1870 .{ }^{14}$ The completion of the Northern Pacific in 1883 connected Portland to a national rail network. ${ }^{15}$ The Pacific Northwest experienced enhanced connectivity to larger markets in only a few decades, allowing for national and international trade networks to expand. Suddenly, the immense resources exclusive to the Pacific Northwest were available in a national marketplace. ${ }^{16}$ During the year $1910,220,000$ freight cars went through Portland's Union Depot. ${ }^{17}$

\footnotetext{
${ }^{11}$ MacColl, The Shaping of a City. 389

12 Ibid. 393

${ }^{13}$ Michael Helquist, "Portland to the Rescue: The Rose City's Response to the 1906 San Francisco Earthquake and Fire," Oregon Historical Quarterly 108, no. 3 (October 1, 2007): 384-409. 387

14 James B. Hedges, "Promotion of Immigration to the Pacific Northwest by the Railroads," The Mississippi Valley Historical Review 15, no. 2 (September 1, 1928): 183-203. 184

${ }^{15}$ Salvatore Prisco, “John Barrett and Oregon Commercial Expansion 1889-1898," Oregon Historical Quarterly 71, no. 2 (June 1, 1970): 141-60. 142

${ }^{16}$ Peter A Kopp, “'Hop Fever' in the Willamette Valley: The Local and Global Roots of a Regional Specialty Crop," Oregon Historical Quarterly 112, no. 4 (December 1, 2011): 406-33. 411

${ }^{17}$ MacColl, The Shaping of a City. 395
} 
Not only were railroads important in the export of goods from the Pacific Northwest, they were also critical to population surges. ${ }^{18}$ Portland saw its first large influx of itinerant workers, recently released from railroad employment, following the completion of the Northern Pacific. ${ }^{19}$ Railroad agencies, in addition to bringing in unemployed populations, also wished to attract more profitable migration. Portland's population booms were, in part, due to the vigilance of rail companies in promoting the Pacific Northwest as a Promised Land. ${ }^{20}$

Portland's successes during this period were due to both the arrival of the transcontinental railroad in 1883 , as well as Portland's status as an exporter and seat of extractive industries in the Pacific Northwest. ${ }^{21}$ While the Alaska Gold Rush pushed Seattle ahead of Portland in terms of population, Portland remained the financial and commercial center of the Pacific Northwest well into the twentieth century. ${ }^{22}$ Carl Abbott refers to Portland during this time period as "the Buenos Aires of Oregon - the dominant commercial and industrial center that connected a growing resource hinterland to the world." ${ }^{23}$ A large working class that became indispensable to the extraction, transportation and construction industries powered this growth. ${ }^{24}$

\footnotetext{
${ }^{18}$ MacColl, Merchants, Money \& Power. 251

19 Ibid. 238

${ }^{20}$ Hedges, "Promotion of Immigration to the Pacific Northwest by the Railroads." 203

${ }^{21}$ MacColl, The Shaping of a City. 51

${ }^{22}$ Carl Abbott, "From Urban Frontier to Metropolitan Region: Oregon's Cities from 1870 to 2008," Oregon Historical Quarterly 110, no. 1 (April 1, 2009): 74-95. 83; Sawyer, "From Whitechapel to Old Town." 122

${ }^{23}$ Abbott, "From Urban Frontier to Metropolitan Region." 77

${ }^{24}$ Carl Abbott, Portland in Three Centuries: The Place and the People (Corvallis: Oregon State University Press, 2011). 50
} 


\section{Pearl of the Pacific: Portland Constructs an Identity}

Portland residents, like many Westerners looking to attract investors and settlers, relied heavily on booster literature and the press to publish a constructed identity. This was immensely important at the turn of the century, as the population of the city increased and became more heterogeneous. This booster literature presented a unified and extremely positive face for the city. The tracts highlighted the good, masked or rephrased the bad, and created a sense that Eden was at hand for anyone willing to travel. In the Overland Monthly, Frederick A. Marriott wrote,

Portland, the Pearl of the Pacific... [a] thoroughly metropolitan city in appearance and in conveniences... Portland has attracted to it men of great wealth, wide business experience and of enterprise. This is seen in the rapid growth in the numerical strength and in the self-evident fact that scarcely anywhere will so much individual wealth be found in a community of the same population. $^{25}$

In January of 1903, journalist Ray Stannard Baker wrote that Portland was,

A fine old city, a bit, as it might be, of central New York - a square with the post office into the center, tree shaded streets, comfortable homes, and plenty of churches and clubs, the signs of conservatism and solid respectability. And yet no decay. $^{26}$

The impressions of Baker and Marriott, echoed in the newspapers and booster literature of the time, painted Portland as a western reiteration of an East Coast metropolis, a place of abundance, both in land, natural resources, and cultural necessities. While these portraits of Portland at the turn of the century ignore the more disreputable

\footnotetext{
${ }^{25}$ MacColl, The Shaping of a City. 307

${ }^{26}$ MacColl, Merchants, Money \& Power. 336
} 
aspects of the city, the consistent theme of conservative ideology acts as a window into how Portlanders of a certain class and influence wanted the city to appear to the outside world.

Historian David M. Wrobel, writing about Western boosterism, argues that the Western tendency to build up the importance of a state or city tapped into an intrinsically Western psychology of optimism that was designed to cover underlying insecurities. ${ }^{27}$ At the turn of the century, Portland boosters tried to convince potential settlers that there were unending opportunities for wealth, but also to show Eastern cities that Portland was inherently separate from the Wild West of popular lore. Wrobel describes this as the need to "emphasize and reemphasize the opportunity while consistently de-emphasizing the hardship." ${ }^{28}$ In addition to separating the modern West from the harsh frontier, boosters also suggested that, even in the most humble beginnings, the West was populated by the very best and most cultured individuals. Wrobel uses an example from the Plains, in which residents of sod houses in Dakota, according to boosters, filled their primitive structures with art, music, and literature. ${ }^{29}$

Historian William Robbins writes that Oregon relied on an idea of prosperity in the region,

The Oregon country in particular, according to its boosters, was a land abounding with potential, a place where nature's wealth and human technical genius would combine to forge the good society, to provide decent, stable living to coming generations.

\footnotetext{
${ }^{27}$ David M. Wrobel, Promised Lands: Promotion, Memory, and the Creation of the American West, First edition (Lawrence: University Press of Kansas, 2002). 6

${ }^{28}$ Ibid. 25

${ }^{29}$ Ibid. 28
} 
He argues the landscape itself, the abundant natural resources of the Pacific Northwest, fueled the mythology which remained influential enough to guide migration to the area. ${ }^{30}$ Robbins writes, "It can be said with some accuracy that. . . the relationship. . . between human activity and environmental/ecological change assumed a more assertive and confident - even arrogant- tone with the onset of the industrial era." ${ }^{31}$ The land itself was rife with possibilities, and the industrial nature of Western man turned that possibility into economic prosperity. Money, according to boosters, was there for the taking.

Oregon's boosters and wealthy elites created a culture of domesticity to operate in tandem with abundant wealth and frontier heroism. While Frederick Jackson Turner's pivotal essay of the frontier experience was still a few years away in 1890, the tenets of his philosophy on the American experience already existed in public perceptions of the American West. Turner focused the Western narrative as a journey from savagery to civilization, placing extreme importance on the taming of the West. Booster literature of the period echoed the importance of civilization over continuous migration. Turner argued that the movement westward was a uniquely American experience, but the creation of America in the West required families with homes, and stood in contrast to mining and gold rush communities.

\footnotetext{
${ }^{30}$ William G. Robbins, Landscapes of Promise: The Oregon Story, 1800-1940, Kindle Edition (University of Washington Press, 2009). 3187

${ }^{31}$ Ibid. 3204
} 
Historian Mansel G. Blackford suggested that the importance of establishing influence over the reputation of Portland was tied directly to the explosive growth that the city was experiencing.

[Business leaders] equated growth with progress, but they were afraid that growth might erode their social influence and physical control over the city. . . Businessmen wanted Portland to grow and expand, but only along lines socially acceptable to themselves. ${ }^{32}$

The founders of Portland's elite class advocated for city beautification, establishment of cultural and scholarly institutions, and the creation of a historical society designed, in part, to glorify the pioneer heritage of Portland's founding families. ${ }^{33}$ The Portland Art Association was established in $1888 .^{34}$ The Portland Hotel, one of the premier gathering places for the elites of the city, opened April of $1890 .^{35}$ By 1894 , Portland had one church for every 600 residents and in 1902, Portland opened its first public library. ${ }^{36}$ By 1903 there were 12,233 registered library users. ${ }^{37}$ On a more direct level, wealthy Portlanders created a community that actively ignored the unskilled working classes within the city. An example of this is the "Portland '400' Directory" which listed and linked the wealthy elites of Portland and the upper class clubs and restaurants within the city. Directories such as these created a city within a city, allowing the Portland elite to avoid those of lower classes. ${ }^{38}$

\footnotetext{
32 MacColl, Merchants, Money \& Power. 337

33 Ibid. 290

${ }^{34}$ Ibid. 319

${ }^{35}$ MacColl, The Shaping of a City. 85

${ }^{36}$ Ibid. 178, 180

${ }^{37}$ Cheryl Gunselman, "'Illumino' for All: Opening the Library Association of Portland to the Public, 19001903," Libraries \& Culture 36, no. 3 (July 1, 2001): 432-64. 457

${ }^{38}$ Abbott, Portland in Three Centuries. 64
} 
Perhaps the most ostentatious example of the widespread boosterism during this time period was the Lewis and Clark Centennial Exposition in 1905. Historian Carl Abbott wrote, "the ostensible purpose was to memorialize the great explorers, but impetus and organization came from bankers, brokers, and the Board of Trade." ${ }^{39}$ A reporter with the Oregonian wrote shortly after the close of the fair "the Lewis and Clark Exposition officially marked the end of the old and the beginning of the new Oregon." ${ }^{40}$ The Exposition advertised the wealth and prosperity of the Pacific Northwest as well as the infinite trading opportunities available, with Portland acting as a gateway to worldwide markets. The fair was immensely popular, attracting $1,588,000$ visitors. ${ }^{41}$ However, after the Exposition closed, the glamorous buildings were demolished by the city and the land returned to those who leased it to the fair. The Exposition was "a lively and luxurious show that was thoroughly enjoyed by all who attended ... in terms of furnishing some significant vehicle for meeting basic urban needs it proved useless. It was escapist and cosmetic in nature." ${ }^{42}$ The Exposition stands as a metaphor for the majority of these booster enterprises. While superficially improving the city, elites made no effort to create lasting changes to already ingrained issues of vice and poverty.

While the Exposition highlighted the existing wealth and prosperity of the land, newly created Oregon pioneer and historical societies created an origin story that idolized the founders of the city. The making of the Oregon myth extends as far back as

\footnotetext{
${ }^{39}$ MacColl, Merchants, Money \& Power. 337

${ }^{40}$ Robbins, Landscapes of Promise. 3553

${ }^{41}$ Lisa Blee, “Completing Lewis and Clark's Westward March: Exhibiting a History of Empire at the 1905 Portland World's Fair," Oregon Historical Quarterly 106, no. 2 (July 1, 2005): 232-53. 251

${ }^{42}$ MacColl, The Shaping of a City. 269
} 
1873 with the creation of the Oregon Pioneer Association, but gained momentum in 1898 with the formation of the Oregon Historical Society. ${ }^{43}$ Both groups had strong ties to wealthy elites who traced their empires to the founding days of the city of Portland. Moving beyond the exclusive glorification and preservation of the pioneer experience, which was the goal of the Oregon Pioneer Association, the Oregon Historical Society tapped into prevailing historical thinking of the time and focused on the movement from savagery to civilization. This mythology of the white settler relied heavily on the concept that only the strongest men would make the journey west, and so only the strongest men became the founders of Portland. ${ }^{44}$

An early contributor to the Oregon frontier mythology was Thomas Condon, a founding faculty member at the University of Oregon. His essay, "The Process and Selection in Oregon Pioneer Settlement," suggested specifically that overland migrants who came to Oregon between 1843 and 1867 were ideally suited, mentally and physically, to establish the Oregon territory. ${ }^{45}$ Condon's essay, widely read in the Pacific Northwest, created an origin story that defined and unified the state while also drawing distinct lines between original Oregonians and those who did not possess the strength of character of the pioneer class. He argued that the journey itself prevented the very

\footnotetext{
${ }^{43}$ Rick Harmon, "Thomas Condon and the 'Natural Selection' of Oregon Pioneers," Oregon Historical Quarterly 99, no. 4 (December 1, 1998): 436-71. 448; Amanda Laugeson, "George Himes, F. G. Young, and the Early Years of the Oregon Historical Society," Oregon Historical Quarterly 101, no. 1 (April 1, 2000): 18-39. 23

${ }^{44}$ Laugeson, "George Himes, F. G. Young, and the Early Years of the Oregon Historical Society." 33

${ }^{45}$ Harmon, "Thomas Condon and the 'Natural Selection' of Oregon Pioneers." 437
} 
rich or very poor from coming West, which in turn created the homogenous population of Oregon. $^{46}$

Condon also focused his essay, not on the single male westerner, but on the family. "Let it be remembered, too, that all this fearful risk was to be borne by women and children." ${ }^{47}$ While Portland no doubt contained a large number of single men at its founding, the city founders instead linked Portland to the idea of the pioneer family, riding through the dangers of the West by wagon train with the goal of community, rather than wealth and exploitation. For Condon, the Oregon pioneers were "men in the prime of life with small families." ${ }^{48}$ Civilizing the American West, it seems, was in the very DNA of the Oregonian.

The myth of Portland - an ideally situated empire, a land of only the best and brightest, a homogenous population without the troubles of the more heterogeneous urban environments of the East - perpetuated itself through the booster literature of the railroads, national magazines, and Portland's own Oregonian and Oregon Journal newspapers, which were the dominant newspapers in Oregon, Southwestern Washington, and parts of Idaho. ${ }^{49}$ Portland, by the turn of the century, successfully created an identity that would be perpetuated through its newspapers for decades to come. Oregonian editor Harvey Scott was one of Portland's greatest advocates. The Oregonian published one of his pro-Portland tracts on January 1, 1891 in which he

\footnotetext{
46 Ibid. 445

${ }^{47}$ Thomas Condon, "The Process of Selection in Oregon Pioneer Settlement," The Quarterly of the Oregon Historical Society 1, no. 1 (March 1, 1900): 60-65. 62

${ }^{48}$ Ibid. 65

${ }^{49}$ Abbott, "From Urban Frontier to Metropolitan Region." 84
} 
explained that Portland was not a boom town that was likely to bust, but rather a city with a steady business district, a strong banking empire, that grew proportionate to need, not according to greed or opportunity.

Portland is looked to universally as a steadying force in business and affairs. No one expects a serious reverse here. Now that financial stringency is settling in, the fame of Portland as a solid city is rapidly becoming wider and more enviable than that which other places have obtained though their extraordinary overgrowth in short periods of "booming." 50

Scott, like other boosters, separated Portland's prosperity from the prosperity of other cities in the American West that were held hostage to the boom and bust cycles of mining or other extractive industries. Instead, Scott argued, Portland was an echo of Eastern refinement and wealth. The problems of the era, namely poverty, slums, and depressions, did not impact Portland because the city itself had a finer stock of people, the sort of fiscally conservative individuals who would not mortgage the city's future for momentary gains. Years later, an Oregonian society editor agreed, saying "The period between 1900 and 1914 found Portland gayer than even before or since in its history." ${ }^{51}$

The mythology of the staid, harmonious city of Portland lasted longer than the first years of the twentieth century; myth making around a Portland identity continues today as the city is imbued with a homogenous identity of liberal idealism. However, this mythology was not without its complications. There is no doubt, given census and economic reports of the time period, that Portland was excelling as a city at the turn of the century, with the exception of nationwide depressions. However, that success

\footnotetext{
${ }^{50}$ H.W Scott, "The Era of Progress," The Oregonian, January 1, 1891.

${ }^{51}$ MacColl, The Shaping of a City. 231
} 
depended on the exploitation of both people and resources as extraction and farming industries surged in the Pacific Northwest.

\section{Creation of an Industrial Empire}

The areas surrounding the Portland metropolitan area were rich in a variety of resources that were integral to the growth and prosperity of the city itself. The fact that Portland sat atop this resource rich landscape was another important component of the identity creation of the metropolitan area. Agricultural enterprise, according to boosters, was a promising path to joining the ranks of the elite. ${ }^{52}$ Wrobel cites the booklet "Oregon, Washington, Idaho and Their Resources: Mecca of the Home seeker and Investor," published in 1904, as an example of this tendency. This publication describes Portland as "a magnificent and imperishable art gallery of verdure-clad and lofty mountains ... [That] look upon fertile valleys that fairly groan with the weight of golden grain and fruit." ${ }^{53}$ While perhaps more colorful than the average agricultural report, this piece of booster literature was not entirely untrue, the Willamette Valley and surrounding areas were a key component in the creation of Portland and offered a select few an abundance of opportunity.

One of the first large international exports was wheat, which was a leading export in the 1880 s. Wheat's importance continued to grow and from July 1,1905 , to May 1 , 1906, almost ten million bushels of wheat and over one million barrels of flour were

\footnotetext{
${ }^{52}$ Wrobel, Promised Lands. 58

${ }^{53}$ Ibid. 62
} 
exported from the Pacific Northwest. ${ }^{54}$ The explosion of the wheat industry was due, in part, to the arrival of the Northern Pacific in Spokane in 1881, which triggered a settlement rush. ${ }^{55}$ Lumber manufacturing was the second leading industry in the 1880 's. Portland was considered the number one lumber-manufacturing city in the United States by 1905, and five years later over 700 million board feet of timber was cut by Portland industries, which created $\$ 10$ million in revenue. ${ }^{56}$ Following lumber, foundry and machine work was the next largest Portland industry in the same time period. $^{57}$

In addition to wheat and lumber, areas surrounding Portland had a thriving fruit and farming industry. In the 1890s the number of farms in Washington State nearly doubled, reaching 33,202 by the end of the century and 56,192 by 1910 . Oregon had 35,837 farms in $1900,45,902$ in $1910 .^{58}$ In addition to railroads, extensive irrigation systems opened up the West to intensive farming that otherwise would not have been possible. ${ }^{59}$ Failed farmers from the Middle West flocked to the Inland Empire, defined as Eastern Oregon, Washington and Idaho, after reading promises from boosters that this was a land of fertility that guaranteed success. ${ }^{60}$

Planters grew everything from apples, which, according to Sunset Magazine, commanded the highest prices in New York, to hops, quickly becoming the world's

\footnotetext{
${ }^{54}$ MacColl, Merchants, Money \& Power. 384

${ }^{55}$ Wyman, Hoboes. 1194

${ }^{56}$ MacColl, The Shaping of a City. 393

${ }^{57}$ MacColl, Merchants, Money \& Power. 237

${ }^{58}$ Wyman, Hoboes. 1215

${ }^{59}$ lbid. 84

${ }^{60}$ Hedges, "Promotion of Immigration to the Pacific Northwest by the Railroads." 195
} 
leading hop exporter by $1905 .{ }^{61,62}$ Even as foreign commodity exports slowed in the 1890 's, domestic business for agricultural products was robust. ${ }^{63}$ One Pacific Northwest farmer noted that 1904 was "the first year that a special berry train was ever run out of Hood River, the O.R. \& N. furnishing a special strawberry train, running straight through from here to Omaha on passenger time." ${ }^{64}$ The commonality running through these industries was the need for large migratory labor populations to sustain them. Without a ready stream of laborers, the economy of the Pacific Northwest would not be able to maintain its growth.

\section{Migrant Labor to Run an Empire}

The industries of the Pacific Northwest created the prosperity that Portland enjoyed in the decades surrounding the turn of the century, but also required a large and mobile labor force to sustain that prosperity. Lumber, wheat, and fruit industries relied on large work forces during only select months out of the year. As these industries thrived, they required more labor, attracting more unskilled workers into the area for work. Because of the newly created railroad infrastructure, this population of itinerant labor was extremely mobile and adaptable. ${ }^{65}$ Peter Boag calls this period the heyday of the casual laborer due to the "abundance of low-skill, seasonal, and labor-intensive jobs

\footnotetext{
${ }^{61}$ MacColl, The Shaping of a City. 310

62 Kopp, “'Hop Fever' in the Willamette Valley." 406

63 Sawyer, "From Whitechapel to Old Town." 121

${ }^{64}$ Wyman, Hoboes. 298

${ }^{65}$ Palmateer, "Charity and the 'Tramp.'"229
} 
that still had not felt the full effects of mechanization."66

In 1876, the New York Times noted great numbers of "migratory, poverty-stricken individuals" in the West stealing train rides with "an unlimited amount of cheek." ${ }^{67}$ This travelling army of laborers was employed in a wide array of skilled and unskilled industries such as mining, logging, milling, canning, and agriculture. ${ }^{68}$ In the Northwest, there were fewer skilled workers and craftsmen and more manual laborers than in more established regions. ${ }^{69}$ Northwest laborers were 'human machines' that exchanged physical labor for a daily wage. ${ }^{70}$ Historian Carlos Schwantes described this period as the wageworkers' frontier, "a land on the periphery of the industrial world that juxtaposed the worst features of wage work with elements of a recent frontier past." ${ }^{71}$ The key features of the wageworkers' frontier were extreme mobility of populations and frequent unemployment due to the boom and bust cycles combined with seasonality of labor in the Northwest. ${ }^{72}$

It is hard to estimate how many migrant laborers were travelling across the country at the turn of the century. Census takers either did not include these individuals in population counts because of their inherent mobility or included them in more than one location; one estimate puts the total number of itinerant laborers at 500,000 in the

\footnotetext{
${ }^{66}$ Peter Boag, Same-Sex Affairs: Constructing and Controlling Homosexuality in the Pacific Northwest, 1st ed. (University of California Press, 2003). 231

${ }^{67}$ DePastino, Citizen Hobo. 66

${ }^{68}$ Carlos A. Schwantes, "Images of the Wageworkers' Frontier," Montana: The Magazine of Western History 38, no. 4 (October 1, 1988): 38-49. 38

${ }^{69}$ lbid. 38

${ }^{70}$ lbid. 40

${ }^{71}$ lbid. 38

72 DePastino, Citizen Hobo. 66
} 
United States by $1906 .^{73}$ In 1900 , the second and third most popular jobs for men were non-farm laborers (12\%) and farm laborers (10\%). ${ }^{74}$ Over half of those who made up the migrant labor population during this period were white, native born, and young. ${ }^{75}$ Black men in unskilled labor positions were unlikely to travel in the same manner due to race restrictions and general intolerance that limited employment opportunities.

Black migrants could not count on the already haphazard kindness of strangers not to mention railroads, missions, and municipal authorities - upon which transient homeless so often depended. ${ }^{76}$

The same was true of Asian, Mexican and Eastern European laborers. While they usually occupied unskilled labor positions, they could not travel from site to site with the ease afforded to white men. ${ }^{77}$ There are exceptions, such as Native American hop-pickers in the Pacific Northwest, but generally speaking, those called hobos were white men. Popular accounts of the hobo menace assumed that the majority of transient laborers were foreign born, usually Irish, but this is likely a reflection of nativist attitudes towards recent immigrants rather than an indicative characteristic of the population at the time. ${ }^{78}$ Arrest records in Spokane in 1913 note that of the 492 arrested for infractions associated with itinerancy (vagrancy and drunkenness), 260 were native-born whites. ${ }^{79}$

Whatever their numbers, unskilled transient laborers became a fixture in the American West, where industries required cheap and mobile labor. Migratory patterns

\footnotetext{
${ }^{73}$ Cresswell, The Tramp in America. 613

${ }^{74}$ Tom Fuller and Art Ayre, Oregon at Work: 1859-2009 (Portland, Or.: Ooligan Press, 2009). 64

${ }^{75}$ Cresswell, The Tramp in America.

${ }^{76}$ DePastino, Citizen Hobo. 14

77 Ibid. 77

${ }^{78}$ Cresswell, The Tramp in America. 632

${ }^{79}$ Wyman, Hoboes. 837
} 
of this population, especially in the Pacific Northwest, were fairly predictable. Laborers flooded the fields and lumber camps in the spring and summer when jobs were plentiful and then returned to major urban centers when the season ended because cities had winter work or charitable services necessary during the upcoming months of unemployment. $^{80}$

An unskilled laborer's need to move from site to site for work was, at the time, attributed to an individual's inability to settle. In actuality, mobility was a necessity due to the fluctuations in the market, the seasonal nature of labor in the Pacific Northwest, and the poor treatment of laborers resulted in poor working conditions in camps. ${ }^{81}$ Labor camps differed greatly in the Pacific Northwest in terms of amenities, but, on the whole, the conditions were considered substandard for the men working. One worker remembers labor camps as,

Crowded bunkhouses ... dirty straw, vermin, wet clothes steaming and stinking about the central stove, men pigging together without ventilation, privacy, or means of cleanliness. ${ }^{82}$

Historian David Vaught noted "hop pickers endured excessive dust and pollen, oppressive heat, a contact rash similar to poison oak ... and even the threat of electrocution from an unexpected storm." ${ }^{83}$ Those working in lumber camps,

Faced isolation, back-splitting work, and harsh conditions. Arriving in a lumber camp, the worker faced a paradoxical scene, a cathedral of green lushness formed by mighty 600 -year old tree and desecrated by the sight and smells of the tramp and its boxcar camps and foul air. ${ }^{84}$

\footnotetext{
${ }^{80}$ DePastino, Citizen Hobo. 10

${ }^{81}$ Palmateer, "Charity and the 'Tramp.'” 229

${ }^{82}$ Wyman, Hoboes. 1918

${ }^{83}$ Kopp, "'Hop Fever' in the Willamette Valley." 424

${ }^{84}$ Roger A Bruns, Knights of the Road: A Hobo History (New York: Methuen, 1980). 134
} 
Another writer described lumber camps as "a sad travesty at best." ${ }^{85}$

Poor working conditions explained an itinerant laborer's willingness to move from job to job, even if the industry offered steady employment. Railway statistics from the Southern Pacific and Northwestern Pacific Railroad from January to May 1914, suggested that laborers spent between 8.6 and 11.7 days on each job. Another study suggested that the average job duration in 1914 was fifteen to thirty days in lumber camps, sixty days in mining, thirty days in canning, ten days in construction work, and seven days in harvesting. ${ }^{86}$ Contemporaries recalled that turnover was so high that each job required three crews: one going, one coming, and one on the job. ${ }^{87}$ Because of this constant movement, itinerant laborers became adept at multiple jobs. Historian Mark Wyman notes, "Hop pickers did more than pick hops; miners moved on to logging jobs; railroad construction crews deserted to shock wheat." This strategy differed from laborers in the Great Plains, who were far more likely to work in similar industries for the duration of the season due to a lack of job options for unskilled laborers. ${ }^{88}$

The wages for itinerant laborers could not sustain someone during frequent bouts of unemployment. Even if a worker spent the summer on a lumber camp working daily, he would not have sufficient money to live through a winter of unemployment. ${ }^{89}$ Pay for an unskilled laborer could be as little as $\$ 1.50$ day plus board at the turn of the

\footnotetext{
${ }^{85}$ Wyman, Hoboes. 1922

${ }^{86}$ Schwantes, "Images of the Wageworkers' Frontier." 40

${ }^{87}$ DePastino, Citizen Hobo. 66

${ }^{88}$ Wyman, Hoboes. 1870

${ }^{89}$ lbid. 597
} 
century in the Pacific Northwest. ${ }^{90}$ Given that the cost of living, which was $\$ 751.46$ per year for a family of 5 in 1903, an unskilled laborer needed to work 500 days a year in order to support a family. Since that laborer was likely to spend 3-5 months unemployed, he could not support even himself. ${ }^{91}$ In addition, wages were dependent on the crops, the market, and the availability of labor, all of which could vary drastically from year to year. $^{92}$

An article published in 1897 entitled "Why Some Men Will Not Work" explained that the wages of unskilled laborers barely covered the cost of living.

The offer of $\$ 1.50$ per day by many contractors is a pure delusion, since to earn this $\$ 1.50$ per day for so many days out of the week as employment is furnished, men must pay to a boarding-house, often kept by an agent or partner of the contractor, a weekly sum nearly of quite equal to their average earnings.

Men, the article goes on, must be onsite seven days a week, and pay for boarding for those seven days, whether or not they were earning a wage. In addition, working a full week was unlikely, given the whims of the markets, the weather, and machinery. Essentially, a worker paid a large portion of his earnings back to the employer for meals and lodging, leaving the unskilled laborer with very little in terms of profit. Given this system, men would often decide to cast off labor and linger in cities rather than find work, as either resulted in poverty. ${ }^{93}$

The pressing need for itinerant labor during parts of the year created an odd relationship between growers, laborers, and towns that were required to manage

\footnotetext{
90 "Why Some Men Will Not Work" Oregonian. January 9, 1897

${ }^{91}$ United States., "Bulletin of the Bureau of Labor," Bulletin of the United States Bureau of Labor, 1913 1903, 53 v. 1138

${ }^{92}$ Wyman, Hoboes. 515

93 "Why Some Men Will Not Work" Oregonian. January 9, 1897
} 
sudden influxes of unemployed men. For crops such as wheat, apples, and hops, farmers required a large number of laborers to be ready to harvest the crop at the exact moment it ripened, otherwise the farm would lose a portion of the crop that year. ${ }^{94}$ Despite the existence of urban centers in the Pacific Northwest, the vast majority of the region was extremely sparsely populated, meaning that adequate labor would have to be brought in. ${ }^{95}$ Laborers flocked to transportation hubs, areas easily accessible by train, leaving more remote farms without adequate labor for harvesting. ${ }^{96}$ Because harvests were so unpredictable, transient populations sometimes crowded into towns that had no use for them while neighboring towns were losing their crops. ${ }^{97}$ Noticing this trend, one investigator noted that in the Pacific Northwest there was an "immense reserve labor force because there must be." 98

In addition, the distances between jobs meant that sometimes workers could not get to the field that needed them before the season was over. ${ }^{99}$ Travel itself was a great risk among itinerant laborers who were rarely in a position to purchase a train ticket. Instead, laborers hopped trains, which, according to the Interstate Commerce Commission, caused the deaths of approximately 25,000 people between 1901 and 1905 in the United States. This number doubles if individuals who were seriously injured in train jumping accidents are included. ${ }^{100}$ Accidents and falls were common, but there

\footnotetext{
${ }^{94}$ Wyman, Hoboes. 600

${ }^{95}$ Ibid. 1874

96 Ibid. 814

97 Ibid. 102

98 Ibid. 113

99 Sawyer, "From Whitechapel to Old Town." 240

${ }^{100}$ Bruns, Knights of the Road. 15
} 
were also reported incidences of unemployed laborers being thrown from trains or killed by brakemen who would not tolerate individuals getting a free ride. These acts of violence went largely unpunished. ${ }^{101}$ Still, despite the risks facing the mobile working class, the number of itinerant laborers continued to grow nationwide with 1910 marking a highpoint in the number of seasonal laborers in the United States. ${ }^{102}$

\section{Hobos in Portland - Emergence of the North End}

I'd been bumming for years then. I was an old hand at it. So I started looking for the Skid Row down on Burnside. I don't know if I had to ask. I found it by instinct, I guess. ${ }^{103}$ - Forrest Balliet, Portland

While the hinterlands of the Pacific Northwest were key to the transient laborer's livelihood, urban centers served as gathering places during bouts of unemployment.

These areas housed brothels, cheap lodging houses, employment agencies, saloons, and gambling establishments as well as charitable organizations and churches. Carl Abbott argues that the addition of bridges and streetcar lines in the late nineteenth and early twentieth centuries allowed Portlanders to segment themselves by race and economic status due to the newfound ease of mobility.

The process created a neighborhood pattern somewhat like an elongated archery target. Downtown was the bull's-eye, surrounded by a ring of neighborhoods for immigrants and unskilled workers. Farther out was a second ring of middle- and upper class neighborhoods, where more established or successful families lived. ${ }^{104}$

\footnotetext{
${ }^{101}$ Wyman, Hoboes. 970

102 Sawyer, "From Whitechapel to Old Town." 33

${ }^{103}$ Transcript Forrest Balliet (1886-?) Oregon Historical Society . 6

${ }^{104}$ Abbott, Portland in Three Centuries. 56
} 
Those identified by contemporaries as hobos would congregate within the bull-eyes. In Portland, the bull's-eye was known as the North End, also occasionally referred to as White Chapel or Skid Row, and was bordered by what is now Oak and Glisan and Naito Parkway to Fifth Avenue, now mostly encompassed by the Old Town neighborhood. At the turn of the century, the North End was one of the most diverse neighborhoods in the city, where Chinese, Japanese, and Greek immigrants mixed freely with unskilled male laborers of all nationalities, including native-born whites. ${ }^{105}$ The North End was described as,

Mingled liberally with the 5, 10, and 15 cent eating houses were not only 5-cent beer saloons, but 5 and 10 cent lodging houses, barbers who shave for 5 cents, cut hair for 10 cents, and a place where baths for 'ladies and gents' are furnished for 15 cents. $^{106}$

In the winter, migrant laborers entered the North End to spend what little they earned and take advantage of urban amenities. According to Stuart Holbrook, who was familiar with this era's North End, "You didn't have to ask how to find it, for it had a character of its own."107 One Portland resident described the area around Burnside Street,

The streets from Oak to " $G$ " and from First to Fifth are infested by a class of people, whose residence therein is detrimental to our business and deteriorates the value of our property, causing the moving away of respectable people, and the collection of the worst elements of society. ${ }^{108}$

Within the confines of the city, there were places that "respectable people" lived and worked, and then there was the North End, essentially quarantining the

\footnotetext{
${ }^{105}$ Ibid. 58

${ }^{106}$ Sawyer, "From Whitechapel to Old Town." 202

107 DePastino, Citizen Hobo. 72

${ }^{108}$ Sawyer, "From Whitechapel to Old Town." 125
} 
undesirables from the rest of the city. The North End, like skid row areas in other large cities, served multiple purposes. First, it supplied cheap food, lodging, and entertainment to a largely young male population. Second, it was likely to act as an employment hub, where agencies were located and job opportunities would be posted. And finally, charitable services, such as the Salvation Army, located themselves in skid row districts, meeting those in need where they lived. Because the single male population was confined, for the most part, to the downtown areas, the North End was a frequent target for vice crackdowns and moral reform movements.

Another component of skid row districts were union offices. In Portland, the Industrial Workers of the World, known as the IWW or the Wobblies, arose in 1907 and gained momentum in the Pacific Northwest in the 1910's and 1920's. ${ }^{109}$ This union was unique in that it was open to unskilled laborers, such as miners, loggers, and farmhands, the majority of which would have been termed hoboes by contemporaries. ${ }^{110}$ The IWW headquarters was located in the heart of the North End, on Burnside. ${ }^{111}$ The IWW headquarters offered basic necessities to the hobo class, such as lodging, kitchen facilities, reading rooms, employment information, and meeting halls. ${ }^{112}$ of course, these services came only to those willing to listen to proselytizing of union representatives. Historians estimate that, in California, by 1915 73\% of the floating

\footnotetext{
${ }^{109}$ Boag, Re-Dressing America's Frontier Past. 694

${ }^{110}$ Fuller and Ayre, Oregon at Work. 89

${ }^{111}$ Frederick Bracher, "How It Was Then: The Pacific Northwest in the Twenties," Oregon Historical Quarterly 85, no. 2 (July 1, 1984): 154-80. 15

${ }^{112}$ DePastino, Citizen Hobo. 98
} 
laborers held radical views that would have been consistent with the teachings of the IWW. ${ }^{113}$

It is hard to determine exactly how many itinerants came into Portland's North End each year. Urban historian Chris Sawyer used census data to attempt to estimate the hobo population, placing it at approximately 3,000 individuals in 1890 . According to census records, there were 17,000 men who were unemployed for a portion of the year in 1890 in Portland. Of those 17,000 men, 50 percent were engaged in occupations that were likely to be associated with itinerant laborers, such as logging and agricultural labor, approximately 8,500 men. ${ }^{114}$ Of those 8,500 men, approximately 3,000 lived within the perimeter of the North End and, because of their location in the city, their status as unemployed, and their occupation, Sawyer assumes that these men would have fallen into the category of "hobo." ${ }^{115}$ It is likely, given the nature of work in the Pacific Northwest and Portland's distinction as a transportation hub, that a disproportionately large number of hobos came to this city compared to other towns in the Pacific Northwest.

By 1900, the City Directory estimated Portland's "floating population" as between 5,000 to 6,000 , nearly doubling in 10 years. ${ }^{116}$ In 1910 , overall unemployment rates in Portland were low compared to the national average, coming in at 3.5 percent for ages 21-44. However, when looking at populations in North End lodging houses, the

\footnotetext{
${ }^{113}$ Ibid. 104

${ }^{114}$ Sawyer, "From Whitechapel to Old Town." 186

${ }^{115}$ Ibid. 188

${ }^{116}$ Ibid. 219
} 
unemployment rate increases to somewhere between 10 to 45 percent. ${ }^{117}$ This suggests that as Portland was seeing unprecedented wealth, the lower classes that occupied the North End, many of them likely migrant laborers, remained in a position of poverty. These two classes, however, were linked. The wealth of one often created, or at least relied upon, the poverty of the other.

Despite this reliance, Portland did not offer a warm welcome to itinerant laborers. Instead, Portland, much like the towns that dotted the agricultural areas of the Pacific Northwest, wanted laborers only when they were needed and then they were "cast off, often chased away, forgotten until next year's harvest." ${ }^{118}$ The city was actively seeking cultural and political superiority among Western metropolises and therefore did not treat itinerant laborers as a necessity for continued growth, but rather as the antithesis to the identity wealthy Portlanders wished to convey. The hobo was tied to agricultural abundance but received no benefit from it. He travelled westward like early pioneers, but supposedly lacked in the strength and fortitude of Condon's ideal Oregonian. He lived within the city limits but was not considered a citizen of Portland. The collision between Portland's staid cultural, political, and social institutions and the North End hobo threatened Portland's vision of itself and its culture of prosperity, abundance, and settlement. This threat dictated the city's response to the floating populations upon which their successes were built.

\footnotetext{
${ }^{117}$ Sawyer, "From Whitechapel to Old Town." 275

${ }^{118}$ Wyman, Hoboes. 135
} 


\section{Chapter Two}

\section{Charity for the Unworthy Poor: Portland Responds to the Tramp}

"All mortals who are suffering and without power are hated by their fellow creatures." Frank Bellow, The Tramp: His Tricks, Tallies and Tell-Tales, $1878^{1}$

On December 31, 1910, the Charity Organization Society of Seattle wrote an urgent letter to Portland's City Board of Charities,

What are you doing with the floating men? ... We are getting forty or fifty a day. They are interfering seriously with our work on family cases by absorbing too much of our time. ${ }^{2}$

Seattle's exasperation due to the influx of transient labor was shared among cities across the United States as migrant and seasonal laborers flooded cities in the winter seeking work, food, housing, and in some instances, alms. These floating populations changed the landscape of the city, and, as Seattle's Charity Organization Society noted, interfered with what they believed to be the real work of charitable organizations, to help their permanent resident poor, namely women, children, and the infirmed.

Secretary Walpole, of Portland's Board of Charities replied a week later, urging work tests, essentially forced labor prior to receiving aid, the discontinuance of outdoor relief in the form of handouts and soup kitchens, and a systematized process for weeding the "worthy" from the "unworthy:"

"We sent the men down to the yard to saw the wood for the dealer "by hand"... a card was signed by the supervisor - the man brought it to this office and received payment in return at the rate of a meal and lodging for each hour's work. The number of applicants is materially reduced under this plan ... But the point is -

\footnotetext{
${ }^{1}$ DePastino, Citizen Hobo. 45

${ }^{2}$ Board of Charities/Associated Charities Correspondence 1889-1914, Public Welfare Commission, Box 104/14, State of Oregon Archives, Salem, Oregon.
} 
they were kept busy earning what they received - meals and lodging- clothes or shoes- all had to be worked for. ${ }^{3}$

Under these criteria, Walpole boasted, his organization was only required to help 160 men in December of 1910. Walpole's, and more broadly, Portland's response to the itinerant labor problem during this time period emerges from a murky compound of scientific philanthropy, middle class anxiety, masculine identity, and above all, the clash between the realities of migrant labor and free market idealism.

Waves of migrant laborers, driven from site to site throughout the summer, came to Portland and neighboring cities each winter, as changes in weather dried up the manual labor positions the Western economy relied on. Once inside the confines of these cities, the so-called hobo menace challenged the very tenets of the self-reliant Westerner, demanding assistance, work, and enjoying the institutions of vice that were so carefully downplayed in booster literature. Portland's biases towards these migrant unskilled laborers, despite their intrinsic value to the industries of the city, revealed themselves in editorials and charitable efforts that were put forth by the city from 18901915.

Cycles of concern followed by complacency or even blame were the cornerstones of these efforts. While the tenets of charity during this time period were based on the goal of personal elevation, the response to homeless males, especially those considered "able-bodied," was exactly the opposite. Charitable efforts in Portland during the turn of the century were geared instead towards containing and stultifying them, which

\footnotetext{
${ }^{3}$ Board of Charities/Associated Charities Correspondence 1889-1914, Public Welfare Commission, Box 104/14, State of Oregon Archives, Salem, Oregon.
} 
resulted in a ready population of laborers for menial, unskilled positions and allowed the city to ignore the contradictions between their "city of prosperity" reputation and a large contingent of poor within the city's limits.

\section{Changing Conceptions of Charity}

Charity was undergoing a philosophical change at the end of the nineteenth century. According to historian John T. Cumbler,

Charity in this period has been described as a middle-class response to the social disorder of the late nineteenth century urban America. . . designed to avert the worst consequences of an urban industrial society: pauperism, social atomization, class hostility, and the destruction of family. ${ }^{4}$

Wage labor, mass unemployment, ease of transportation, and boom-bust economic cycles had stretched existing charitable institutions and networks to the breaking point. Social historian Paul T. Ringenbach suggests that the concept of unemployment, along with the concept of the tramp, was fairly new, originating in 1873 among social reformers in New York who responded to urban homeless populations. ${ }^{5}$ While migrant male populations certainly existed before 1873 , the problem was sufficiently widespread at that point to necessitate its own terminology.

Charitable activity in previous decades relied heavily on individual giving, or alms giving, also known as outdoor relief. Reformers believed that this form of charitable handout contributed to increases in dependency, rather than ameliorating the problem of poverty. Outdoor relief, according to minister Edward Hale, an outspoken opponent

\footnotetext{
${ }^{4}$ Cumbler, "The Politics of Charity." 101

${ }^{5}$ Cresswell, The Tramp in America. 112
} 
of the practice, was essentially "reckless generosity" and would only create a culture of poverty. ${ }^{6}$ Reformers argued that immediate relief efforts would only increase the problematic population in their cities. Individual charity, that is, one community member offering aid to another without formal charitable involvement, was heavily discouraged, leaving cities to carry a larger amount of the burden of caring for the poor. The resulting system encouraged both individuals and institutions to leave homeless individuals to fend for themselves, rather than risk helping them in the wrong way. ${ }^{7}$ A charitable movement known as scientific charity emerged in response. Under scientific charity, charitable organizations worked to elevate those in poverty, rather than focus on temporary means of relief through soup kitchens or direct funds. Historians argue that scientific charity fell between two periods of time, an earlier era in which homelessness and poverty was an individual issue, and the Progressive era, when poverty was understood as a societal issue. Charitable organizations that were created during this middle period relied on tenets of the social gospel, which is described as,

The salvation of the 'whole man', body and spirit, and a Christian life 'crowded with fraternal deeds'; a reverence for science which directed attention to system, the elimination of wasted motion; a residual individualism which held each person responsible for his own destiny; 'middle class' anxieties about social disorder and vice and the danger of social upheaval; and a tempered belief in progress. ${ }^{8}$

\footnotetext{
${ }^{6}$ DePastino, Citizen Hobo. 22

${ }^{7}$ Sawyer, "From Whitechapel to Old Town." 199

${ }^{8}$ Jordan, "The Method of Modern Charity." 38
} 
Scientific charity, which acknowledged individual failings but relied on societal uplift, bridged the social work philosophies of the two periods: an earlier period of individual giving and a Progressive era belief in governmental aid. ${ }^{9}$

Issues of homelessness were at the forefront of discussions among sociologists and charitable organizations, however there were no comprehensive measures taken to deal with homelessness on a national level. Instead, each state, city and town had their own laws, charities, and welfare organizations, working occasionally as collaborators, but never in tandem. This meant that populations were treated differently from place to place, with no consistent long term aid available to transient male populations who were unlikely to remain within one municipality.

Scientific charity manifested due to economic and cultural changes occurring during the turn of the century, namely the movement from small close-knit communities to larger urban environments, which, in turn, created a lack of community accountability for poor populations. Historian Amy Stanley argues that the movement away from outdoor relief was directly related to the aftermath of the Civil War, in which paternalistic relationships were viewed with suspicion, as they mimicked the dependence-protection dynamic of the antebellum South of which reformers had been so adamantly opposed. ${ }^{10}$ At the same time, Stanley argues, individuals acted with

\footnotetext{
${ }^{9}$ Kusmer, "The Functions of Organized Charity in the Progressive Era." 657

${ }^{10}$ Stanley, "Beggars Can't Be Choosers." 1265
} 
contempt towards those suffering from poverty, considering it a personal defect, resulting in punishments for vagrancy and homelessness, rather than assistance. ${ }^{11}$

Historian Robert Bremmer argues that between the nineteenth and twentieth centuries, charitable organizations began to consider poverty a societal, rather than personal issue, admitting that poverty was not necessarily the sole fault of the individual. ${ }^{12}$ This philosophical shift, however, was slow and localized and did not necessarily immediately impact the laws, aid, and treatment of those on the street, especially among homeless male populations. Because they were physically able to work but appeared to choose not to, poor men were not a sympathetic group, despite an increasingly obvious connection between the Western labor system and migration of males into cities in the winter.

Rather than seeing inadequate wage labor as a driver of poverty, charities of this time perceived the wage labor system as the antithesis of poverty. According to charitable organizations, the abundance of wage labor at the turn of the century suggested that those without work were physically or morally deficient, and consequently unwilling to contribute to their own support. ${ }^{13}$ Charities implemented forced labor practices believing they needed to teach the poor to contribute rather than receive aid without working. Forced labor, designed to reduced dependency, instead perpetuated a system that relied upon cheap, dependent workers. ${ }^{14}$

\footnotetext{
${ }^{11}$ Ibid. 1288

${ }^{12}$ Jordan, "The Method of Modern Charity." 44

${ }^{13}$ Stanley, "Beggars Can't Be Choosers." 1273

${ }^{14}$ Ibid. 1267
} 
Charitable organizations relied on women to implement some of these initiatives. Women were newly empowered through the tenets of social housekeeping, which gave them authority over the moral wellbeing of society just as they acted as the moral compass of the household. ${ }^{15}$ In addition, the cities' elites funded and maintained these initiatives. Frederic Cople Jaher suggests that this charitable community "generally involved wealth, power, civic pride, noblesse oblige, the need for recognition, and the desire of political-economic elites to strengthen their authority." ${ }^{16}$ The result was a highly gendered and highly politicized approach to addressing poverty in the United States in the decades surrounding the turn of the century. Rather than providing services universally to all populations, scientific charity allowed for the justified exclusion of certain individuals, namely poor males.

\section{Transience as Pathology}

Prevalent psychological theories of the time shaped society's attitudes to the transient male population and provided a foundation for the policies that followed. Charitable organizations used newly created scientific explanations of the hobo pathology to free themselves from obligations to provide assistance. An individual's inability to support himself was usually linked to a hereditary or mental deformity that caused an individual to be unable to conform to standard conceptions of success. If the hobo population could be categorized as pathologically unfit to exist in a civilized society, society itself was no longer required to offer aid. Psychologists responded to the

\footnotetext{
${ }^{15}$ Helquist, "Portland to the Rescue." 392

${ }^{16}$ MacColl, Merchants, Money \& Power. 241
} 
influx of transient laborers in the United States by making their mobility a disorder, which excluded them from charitable services because there was no hope of their elevation.

During this period, the American identity was tied to family and community, but also to freedom of movement and migration. The migrant male's adherence to the latter but not the former created a dissonance that challenged middle and upper class values. ${ }^{17}$ Cities that were built on the concept of the self-made Western identity, therefore, were faced with a distortion of their own mythology. Mobility was such a profound concept in American society that it was actually considered part of the biological makeup of Americans, an ideal that made the American people exceptional. ${ }^{18}$ At the same time, aimlessly wandering, as transient males seemed to do, was a disease according to psychologists. It led to mental confusion, alcohol and drug use, and sexual misconduct. ${ }^{19}$ This disease was known as "fugue," literally translated as flight, and characterized by sudden and inexplicable travel. ${ }^{20}$

The desire to wander excessively without an endpoint rather than migrate and settle, therefore, became a deformity of character. Transient males, in essence, were treading a fine line between a characteristic American identity and a pathology that needed to be studied and addressed. Rather than a symbol of democracy, as the Western narrative had become, sociologists at the turn of the century depicted the

\footnotetext{
${ }^{17}$ Cresswell, The Tramp in America. 162

${ }^{18}$ Ibid. 2133

${ }^{19}$ Ibid. 2142

${ }^{20}$ Ibid. 2146
} 
hobo as an affront to Americanism. Robert Park, a sociologist who studied the transient male and the urban experience at the turn of the century, articulated the distinction between American mobility, a sanctioned and lauded characteristic, and aimless wandering. Hobos, he argued, performed the latter. ${ }^{21}$ The hobo had the freedom to travel, but lacked direction, and this is why he was such a threat. He had no stake in the conventions of society, and therefore could follow or ignore the rules without any consequence to his own wellbeing because he always had the option to relocate. ${ }^{22}$

Sociologists, using these superficially scientific observations, decided that the socalled hobo was beyond repair or re-integration into societal conventions, he was separated "from all influences which can minister to his improvement or elevation." "23 He lacked "commitment, attachment, and involvement" in communities, and without those things, there was no means by which social workers would be able to re-anchor him to a productive existence. ${ }^{24}$ This explanation, of course, exhibits a self-serving blindness to the issues facing the unskilled laboring class. Rather than acknowledging that a transient laborer was forced to abandon community ties and was unable to have or support a family due to low pay, sociologists argued that it was the man himself, not his occupation or the American industrial system, which created a system of unending poverty. In an era in which the self-made man was an important construct, there was no room for a man who was unable to elevate his station through his own labor.

\footnotetext{
${ }^{21}$ Ibid. 1174

22 DePastino, Citizen Hobo. 231

${ }^{23}$ Cresswell, The Tramp in America. 1680

${ }^{24}$ Ibid. 197
} 
There were, however, dissenters in the study of the transient male who believed that the hobo class was not the result of a deformity, but rather an elevation of the American man. Josiah Flynt Willard, author of Tramping with Tramps, published in 1899 was one of the more important and lasting researchers of the hobo lifestyle at the turn of the century. ${ }^{25}$ This autobiographical account details Williard's travels among the hobo class shortly before the turn of the century. The Oregonian described him as the "chronicler of the 'Wanderlust', the interpreter of the joys of the care-free life, the life that knows no work or duty of responsibility except the responsibility of keeping alive." ${ }^{26}$ Willard argued somewhat favorably for the tramp, suggesting they, Are not, as is . . popularly supposed, the scum of the environment. On the contrary, they are above their environment, and are often gifted with talents, which would enable them to do well in any class, could they be only brought to realize its responsibilities and to take advantage of its opportunities. ${ }^{27}$

While others saw the tramps' anonymity, mobility, and self-serving persona threatening, Willard suggested that it was a sign of uncanny intelligence, that these men were unwilling to conform to society, and therefore transcended it. Williard's interpretation of the hobo romanticizes the poverty of the transient male as a choice to live freely and largely ignores the necessity of travel for the laboring class. Willard does not suggest the wage labor system forced men into a lifestyle, but rather that they chose it due to their own sense of adventure.

\footnotetext{
${ }^{25}$ DePastino, Citizen Hobo. 49

26 "Amateur Tramp Goes over Divide" Oregonian January 22, 1907. 2

${ }^{27}$ DePastino, Citizen Hobo. 49
} 
The few advocates of the hobo lifestyle, however, did little to impact the charitable efforts of the turn of the century. Migratory laborers who came into cities seemed to be defective in character and unsuited for elevation. Psychological studies reinforced existing prejudices, creating a foundation based on dubious science to support policies of exclusion, rather than uplift, for the transient male. This justification allowed cities to consider the hobo as an aberration to the successes of the early twentieth century rather than a reflection of an exploitative labor system.

\section{The Able-Bodied Man}

Scientific charity, a well-established doctrine by the beginning of the twentieth century, had solidified the importance of sociological classifications, focused philanthropic endeavors on elevation, and demands of self-determination among poor populations. At the same time, the landscape of poverty was shifting drastically. Vagrancy, which was once a stationary affliction rooted in one community, was now mobile. This created a sense of anonymity to poverty that had not existed in previous decades. Adding to this population of migrant poverty, wage labor, the opening of the West, and seasonal employment dramatically increased the number of transient males dependent on aid. These men had no community ties and were not easily elevated out of their current condition of migrant seasonal labor. The turn of the century also brought the male into scholarly and cultural scrutiny. The concept of masculinity, or what it meant to be a successful man, which was once tied to property, familial success, and moral purity, was slowly shifting to a corporeal sense of manliness. In essence, the 
male form, the strength of a man, and the ability of that man to perform certain feats became equally important to moral or religious fervor.

The influx of seemingly "able bodied" males, therefore, was especially troubling to city authorities and reformers in the late nineteenth century. Men who were physically able to work and support themselves fit into corporeal understandings of the idealized man. However, they simultaneously depended on the aid of the city's charities, resulting in a feminized state of dependence. In addition, an important component of an idealized man was his role as a provider for his immediate family. Men without this attachment became unrecognizable as men to the urban middle class, who put a strong emphasis on their role as provider. The argument of the "able-bodied male," that one should work if one was able to, combined with the city's desire to only assist permanent residents of that city, excluded individuals who had migrated in for the season from receiving assistance. $^{28}$

Mary Richmond, considered by social historians to be the founder of modern social work, wrote in 1899, "like our bodies, [character] may be made whole again by skillful treatment." Skillful treatment, by her definition, focused on such virtues as industry and prudence, which were not present among this subset of the population. ${ }^{29}$ Without a guarantee of moral worth, charity officials were unlikely to expend a significant amount of aid on homeless men. The distribution of aid therefore followed heavily gendered lines: women and children almost universally qualified for aid,

\footnotetext{
${ }^{28}$ Wyman, Hoboes. 933

${ }^{29}$ Stephen T. Ziliak, "Self-Reliance before the Welfare State: Evidence from the Charity Organization Movement in the United States," The Journal of Economic History 64, no. 2 (June 1, 2004): 433-61. 441
} 
whereas men, especially those unattached to family or community, were scrutinized by charitable organizations before given assistance. $^{30}$

An example of this gendered distinction regarding the availability of aid is the work of Portlander Lola Green Baldwin, the first female policewoman in the nation. She was in charge first of the Travelers' Aid Society and later dedicated to women's issues within the police force, most notably issues of vice. Baldwin is one example of a nationwide emergence of female social work. These women, while positively impacting the treatment of poor populations, focused on issues of women and children while almost wholly ignoring issues of poor single men. Baldwin's biographer notes that Baldwin, "in the period between 1890 and World War I, addressed diverse problems affecting women, children, and families." ${ }^{31}$ The consensus among charitable groups was that these men were at the "bottom of a hereditary hierarchy," biologically unable to be elevated, and only able to survive because of individual giving. ${ }^{32}$ While women and children were inherently in a position of dependence, men were expected to maintain a certain level of self-sufficiency.

Charitable initiatives attempted to reconstruct appropriate levels of masculine behavior before transients were granted aid. This most frequently manifested in work tests, essentially free labor extracted from men who applied for assistance. Cities began "employing" transients for municipal projects during economic downturns, paying them

\footnotetext{
${ }^{30}$ Sawyer, "From Whitechapel to Old Town." 27

${ }^{31}$ Gloria Myers, A Municipal Mother: Portland's Lola Greene Baldwin, America's First Policewoman, 1St Edition edition (Corvallis, Or: Oregon State University Press, 1995). 3

${ }^{32}$ Cresswell, The Tramp in America. 2091
} 
in food or shelter rather than wages, and the practice continued well into the twentieth century as a means of busying unemployed men during the slow winter months while also obtaining labor for city projects. ${ }^{33}$ Work tests were also a means of gauging one's willingness to work. Those men who refused to participate in work tests were seen by charitable organizations as unwilling to support themselves and therefore denied aid.

Defense of these work tests, which essentially amounted to involuntary servitude, relied on the idiom of the marketplace. Amy Stanley writes, "As in any bargain, so in almsgiving, they claimed, the beggar owed something in return; a share of labor- surrendered willingly or not- for a portion of food or a night's lodging. ${ }^{\prime 34}$ Charity became a contract relationship, with charitable organizations acting as employers and exacting what was due to them, labor for alms, from transient populations. In this way "the duty to the poor [was] reduced to an exchange of commodities." ${ }^{35}$ Labor advocates immediately latched on to the disparities of forced labor in a free market economy. They argued that turning these men into temporary slaves denied them rights afforded to every man after the conclusion of the Civil War, the right to work as he sees fit for a wage and the ability to travel freely without being penalized or imprisoned. ${ }^{36}$

Labor union representatives did not see poverty, in the case of male laborers, as a choice, but rather the sad reality of a seasonal labor system. Wage labor, they argued, did not signify independence, or even manliness, but rather a system in which the

\footnotetext{
${ }^{33}$ Sawyer, "From Whitechapel to Old Town."198

${ }^{34}$ Stanley, "Beggars Can't Be Choosers." 1290

${ }^{35}$ Ibid. 1292

${ }^{36}$ Ibid. 1281
} 
working class laborer depended, not only on charitable support, but also on the whim of the marketplace and their employers. ${ }^{37}$ Unfortunately, charitable officials and city politicians disagreed, citing work tests as the only means of identifying worthy from unworthy while also re-creating a standard male identity, the able bodied worker, out of the idle poor.

\section{Portland's Charitable Infrastructure}

Portland's charitable infrastructure largely mimicked the larger American landscape, focusing on issues of scientific charity and elevation, rather than direct almsgiving, especially in issues of male homelessness. By the 1880 's, Portland had numerous charitable organizations that catered to specific subsets of the population founded through church and philanthropic groups. Examples of these were the Boys and Girls Aid Society, founded in 1885 to aid children, the Portland Women's Union, founded in 1887 to help working women and the Patton Home of the Friendless, founded in 1889, whose mission was to provide aid for the "afflicted." 38 The first institution established to specifically offer aid to male populations was the Church of Land and Sea, established in 1877 and dedicated to the protection of sailors who frequented Portland docks. $^{39}$

During the Depression of 1893, the need for assistance and the institutions to provide that assistance both increased. In Portland, organizations founded in the last

\footnotetext{
37 Ibid. 1272

${ }^{38}$ MacColl, Merchants, Money \& Power. 241

${ }^{39}$ Sawyer, "From Whitechapel to Old Town." 192
} 
decade of the nineteenth century included the Congregationalist People's Mission, the Union Gospel Mission, the Men's Resort, God's Regular Army, Good Health Restaurant, and the Portland Medical Mission. ${ }^{40}$ In 1901, the YMCA opened in Portland with the stated purpose of elevating their constituency towards wholesome, rather than vice laden, pursuits. ${ }^{41}$ This included vocational training, ostensibly designed to guide men towards employment that would not result in regular unemployment. These institutions, unlike early organizations that focused on women and children, acknowledged that the depression and subsequent economic downturns impacted men as well.

In addition to institutions created specifically for almsgiving, Portland had an abundance of churches, most with a philanthropic department to offer aid. One of the most famous charitable institutions directly tied to a religious mission was the Salvation Army, which was founded in the United States in 1879 in Philadelphia and spread quickly to cities across the country. The purpose of this organization was directly tied to issues of skid row populations, including the newly identified transient male populous. By 1894, the Salvation Army in Portland provided bathing facilities, temporary lodging, and a soup kitchen to be used by the homeless, both men and women. Aid was not freely given, however. The Salvation Army required sermon attendance and either a modest fee or labor in exchange for food and housing. ${ }^{42}$

\footnotetext{
${ }^{40}$ Ibid. 200

${ }^{41}$ Helquist, "Portland to the Rescue." 396

${ }^{42}$ Sawyer, "From Whitechapel to Old Town." 196
} 
While Portland teemed with charities during this period, it is important to note that no charitable institution was interested in or investigating the possibility of altering the businesses or commercial practices that created these large homeless populations. The issue was, according to charitable institutions, individual rather than societal, and therefore it was not the responsibility of businesses to change their practices. This position not only reflected the prevailing social attitudes toward masculinity and morality, but also masked a self-interested pragmatism at the core of Portland's economy. The principle donors behind most of these philanthropic organizations were members of the Portland elite, whose best interests were not to delve into issues of poverty, especially at the cost of their own wealth or status. These organizations were designed to justify current economic systems without challenging the status quo. By ignoring the real issues of substandard pay for unskilled laborers, these institutions made it very hard for the working class to gain momentum or create real and lasting change. $^{43}$

\section{The City Board of Charities}

In 1888 the City Board of Charities (CBC), later renamed the Associated Charities to eliminate confusion regarding its connection to city funds, was founded in Portland to handle cases of aid in a systematized way. ${ }^{44}$ While this organization was by no means

\footnotetext{
${ }^{43}$ Helquist, "Portland to the Rescue." 391

${ }^{44}$ Board of Charities/Associated Charities Correspondence 1889-1914, Public Welfare Commission, Box 103/15, State of Oregon Archives, Salem, Oregon.; Board of Charities/Associated Charities Correspondence 1889-1914, Public Welfare Commission, Box 104, State of Oregon Archives, Salem, Oregon.
} 
the sole provider of aid at the turn of the century, it was the most prominent institution created for the sole purpose of providing aid and left the most detailed records regarding the work that was performed. The $\mathrm{CBC}$ acted as a clearinghouse for aid given within the city of Portland. Rather than individuals or organizations providing direct assistance, all individuals requiring alms went to the Board of Charities for evaluation and, if they qualified for assistance, the CBC would provide aid. Aid was not given equally and not all $\mathrm{CBC}$ revenue went to individuals requiring assistance. More than 60 percent of the funds donated to the $\mathrm{CBC}$ were allocated to staff salaries and office maintenance, and the remaining 40 percent went disproportionately to women and children, despite the increasing need for aid among single males. ${ }^{45}$

Similar institutions were being founded by charitable groups across the United States to deal with the rampant need for systematized aid under the new guidelines of scientific philanthropy. Charity organization societies already existed in twenty five American cities by 1883 , and by 1904, approximately 150 societies existed in the United States with a similar mission and reach to Portland's CBC. ${ }^{46}$ The goal of these organizations was to provide more consistent relief to poor populations while also assuring that the aid was distributed only to worthy individuals. In practice, however, these organizations often devolved into highly subjective entities that were built to pass judgments on the individuals who they purportedly attempted to help, ultimately

\footnotetext{
${ }^{45}$ Sawyer, "From Whitechapel to Old Town." 196

46 Jordan, "The Method of Modern Charity." 36; Kusmer, "The Functions of Organized Charity in the Progressive Era." 658
} 
justifying inaction. ${ }^{47}$ The City Board of Charities, like most charitable organizations, had no connection to the city government and was supported through private donations and memberships. In fact, it would be rare to have city officials weigh in on issues of poverty or relief during this time period. Most charitable officials saw poverty as a cultural rather than economic issue, and therefore government intervention was not seen as necessary or even constructive. ${ }^{48}$

The goal of the $\mathrm{CBC}$ was not necessarily to cater to the needs of the populations it was serving, but rather to meet the needs of society as a whole. The CBC's role was to preserve middle class interests while assuaging the moral burden to alleviate the poverty visible around them, controlling populations who threatened social order, and preventing the city from falling victim to "an epoch of cascading moral, economic, and social problems. ${ }^{49}$ The CBC aimed to counteract the negative effects of the city on moral order by eliminating outdoor relief, creating work tests to evaluate worth, and creating a "Friendly Visitor" program, which was described as "no alms but a friend," that allowed poor families to interact with a model Portland citizen, usually a female of an upper class. ${ }^{50}$ If an individual qualified for aid, the CBC offered food, lodging, medical treatment, job assistance, or train tickets to return individuals to their families or communities of origin. The CBC defined their main objectives as "procuring employment for the needy that can work, providing immediate relief, and repression of mendicancy

\footnotetext{
${ }^{47}$ Kusmer, "The Functions of Organized Charity in the Progressive Era." 663

48 Ibid. 668

49 Jordan, "The Method of Modern Charity." 45

${ }^{50}$ Board of Charities/Associated Charities Correspondence 1889-1914, Public Welfare Commission, Box 102, State of Oregon Archives, Salem, Oregon.
} 
and exposure of impostors. ${ }^{\prime 15}$ For the hobo class, the latter seemed to be the most vigorously pursued.

\section{The Work of the City Board of Charities}

The first campaign of the CBC, under the direction of President Thomas Strong, was to eliminate outdoor relief, defined as direct almsgiving and soup kitchens, which, he believed, caused an increase in issues of vagrancy. In a letter distributed to 5,000 households in June of 1890, Thomas Strong wrote,

Never give anything to beggars; circulators of beginning subscription papers or applicants for relief of any kind, except such as you know to be worthy. Refer all others to our office. We will not turn away unaided any needy or deserving persons, whatever their character or position. If you will use us in this work we will rid the city of tramps and beggars, and devote the money hitherto used on them to its proper use, the care of the deserving poor.

Strong's goal, and thus the goal of the organization, was to force "the professional tramp and beggar to earn an honest living." ${ }^{52}$ The $C B C$ provided citizens with cards to hand to those in need of assistance. The recipient of a card brought it to the City Board of Charities. The CBC investigated the individual and, once vetted properly, the individual would receive the aid indicated on the card by the original "good Samaritan." Individuals needed to be vetted before assisted to avoid the distribution of limited

\footnotetext{
${ }^{51}$ Sawyer, "From Whitechapel to Old Town." 196

52 Board of Charities/Associated Charities Correspondence 1889-1914, Public Welfare Commission, Box 102, State of Oregon Archives, Salem, Oregon.
} 
resources to "imposters," and it was the responsibility of the CBC to provide aid to only those who were worthy. ${ }^{53}$

Ending outdoor relief that was commonly administered by churches in the late nineteenth century left the $\mathrm{CBC}$ as the gatekeeper of aid, imbuing it with the de facto authority to judge the "worthy" and "unworthy." In 1889, shortly after the formation of the City Board of Charities, the mood towards itinerant labor was cautiously optimistic. Board Secretary W.G Steel wrote, "Although the majority of our applicants are honest and seek work in good faith, we have quite a number who are not by any means angels with white-washed wings." ${ }^{54}$ The Board separated the willing but needy workers from the deliberately idle. In doing this, however, a system of poverty was created in Portland that trapped the male migrant worker. This system maintained the status quo without the philanthropic promise of elevation for the transient male.

In his 1890 annual message, Thomas Strong acknowledged the difficulties of discerning the worthy from the unworthy, but assured the community that they were too kind rather than too strict on the population of Portland.

You will all recognize the difficulty of this task in drawing the line over the debatable ground between the needy poor and the professional mendicant and that in this most difficult task any man may err. It is but in justice to add that in no case has it been discovered that the secretary has been in error in branding a mendicant as an imposter. If any error has been committed it has been in the other direction. $^{55}$

The goal of the $\mathrm{CBC}$, especially when dealing with homeless male populations, was to

\footnotetext{
53 "Board of City Charities: Their Work of Providing for the Needy Begins in Earnest - Instructions to the Public." Oregonian January 30, 1889. 8

54 "Some are Bent on Swindling." Oregonian March 2, 1889.

55 "City Board of Charities Annual Meeting Held" Oregonian. December 20, 1890
} 
force those "able-bodied" males back to work by shutting off the well of aid. In the winter, however, there was no work to return to for migrants, who worked as field hands, lumber men, or railroad workers.

One letter from the Seattle Board of Charities written in 1897 echoes the view of the Portland $C B C$,

The object of the society is not so much to give gratuitous aid, as to assist unemployed persons in helping themselves. It is our special aim to assist ablebodied men of families to find employment for the support of those dependent upon them. ${ }^{56}$

Seattle, like Portland, had an unwritten hierarchy of aid. Women and children were the highest priority, followed by the old or provably infirmed, followed by men with families and/or community ties, leaving floating male populations at the bottom and subsequently the least likely to be helped or even to be considered in need of help. This did not mean that men were unlikely to approach the $\mathrm{CBC}$, but rather that they were unlikely to receive aid or even to be counted against the demand for aid that the CBC was able to meet.

Women approaching the $\mathrm{CBC}$ had a very different experience than the men who did the same. In her discussion of Lola Baldwin, historian Gloria E. Myers mentions a 1907 incident involving a woman named Caroline. Lola Baldwin, at that point working with the Portland Police, personally escorted Caroline to the CBC offices, which provided Caroline with emergency food and shelter. Following this assistance for her immediate needs, Baldwin took Caroline to the Nurse's Association for an examination and

\footnotetext{
${ }^{56}$ Board of Charities/Associated Charities Correspondence 1889-1914, Public Welfare Commission, Box 102, State of Oregon Archives, Salem, Oregon.
} 
admitted her to the Good Samaritan Hospital for an emergency Caesarean section. Once she had adequately recovered, the CBC gave her a job as a housekeeper, free childcare for her infant while she was working, and a supply of baby clothes. In addition, Baldwin personally assisted her in filing charges against the father of her child for abandonment. $^{57}$

Men who came to the $\mathrm{CBC}$ were more likely to be scrutinized and less likely to receive assistance. Records indicate that a key component of determining who received aid among the male population was the existence of provable community ties or demonstrably temporary or circumstantial poverty. Letters back and forth from city to city created a paper trail of these investigations; each man was thoroughly scrutinized unless a city official or reputable citizen was willing to provide a letter of reference. However thorough the investigation, the final determination was arbitrary and subjective, based on the prejudices of the $\mathrm{CBC}$ and the belief in Portland during this time period that, with the exception of nationwide economic downturns, there was no good reason to be poor. Entrenched poverty simply did not fit into proper society, of which Portland was an example. To justify the rejection of a large portion of Portland poor, the City Board of Charities stated,

There is no excuse for anyone begging in Portland, for the board of charities always provides or procures necessary aid without delay. Of course, help cannot always be given in a way to please the applicant, since that would often defeat the very object we wish to accomplish. ${ }^{58}$

\footnotetext{
${ }^{57}$ Myers, A Municipal Mother. 17

58 "Don't Give to Beggars: Secretary Walpole Says all Worthy Cases Are Taken Care Of" Oregonian August 5, 1894. 12
} 
Determinations of aid were based on superficial judgments of character and whether or not the CBC believed that one should be able to get by on one's own, without the city's assistance. A meal could be refused to a man simply because he looked healthy enough to work. One aid seeker was bounced from the Hebrew Benevolent Association to a local merchant and finally to the City Board of Charities on December 19, 1893. He required a ticket to San Francisco, likely for work. The letter he brought to the $\mathrm{CBC}$ from the Hebrew Benevolent Association said that he was denied aid because "a young man in this fellow's position with apparently perfect health should not be a burden on any charitable organization and that he should be able to shift for himself." 59

The $\mathrm{CBC}$ answered this man's pleas and he was given a charity rate for a train fare out of town. However, those without the presence of mind to continue with persistence were often forced to rely on skid row district saloons and lodging houses rather than charitable assistance. Scientific charity, in essence, removed the moral obligation to help one's fellow man, allowing, in its place, moral grandstanding and exclusionary practices against subsets of the population who were deemed dangerous to the status quo.

\section{Providing "Honest" Work}

On January 2, 1891, the Oregonian ran an article recounting that 200 men, recently released from work on the Union Pacific railway, had flooded the city with

\footnotetext{
${ }^{59}$ Board of Charities/Associated Charities Correspondence 1889-1914, Public Welfare Commission, Box 102, State of Oregon Archives, Salem, Oregon.
} 
timecards that the railway was unable to cash due to a lack of funds. The railroad workers were,

Making the city jail their headquarters; although the apartments there are too crowded to meet the sanitary requirements of a model home ... the board they receive is as good as any furnished by a B class hotel, and they have no reason to complain. $^{60}$

These men, it is important to note, earned a wage that was not paid. Still, as they arrived to the city as a transient population and were currently without work, the floor of the city jail was, according to the Oregonian, more than adequate.

The real concern of the city was not the fate of the men, who had not received the money owed to them, but rather the tendency of idleness. CBC Secretary Walpole implored the city to provide odd jobs to occupy the men, teaching them a sense of selfreliance. In 1891, sympathies were high for the railroad workers, Portlanders held a benefit at the Grand Marquam, the Unitarian church provided a dinner, and the City Board of Charities worked to secure employment for the men within the city. ${ }^{61}$ As the decade continued, these sympathies from Portlanders would turn to fatigue, and charitable organizations would move from uplift to containment. However, the fear of idle men was a reoccurring theme among charity officials during this period. If men were to come into the city, the city needed to find out how to make them work.

The CBC was again tested in the winter of 1893 , at the height of a nationwide economic downturn. Mayor Mason wrote to Secretary Walpole for advice, reiterating

\footnotetext{
60 "Work for the Worthy: The Deserving Laborers Are to be Given and Opportunity" Oregonian January 2 1891. 5

61 ibid.
} 
that, even in times of great economic depression, handouts were not the answer: "I am opposed to the free soup houses project. When the majority of men get down so low as to accept charity- their self respect is gone." ${ }^{62}$ City officials believed that a single act of kindness or alms would destroy a man's willingness to work. If one could survive on the back of another's labor, why would one return to the railroads, lumber camps, or fields when one was needed? In other words, a system of handouts would threaten the economy on which Portland was dependent.

Work tests, according to the $\mathrm{CBC}$, were the answer. They would serve as a tangible metric to determine worthiness and also keep men from resorting to idle behavior. The $\mathrm{CBC}^{\prime}$ 's primary tenet was that they were only obligated to help those willing to help themselves. ${ }^{63}$ Work tests would determine, without a doubt, if men were willing to support themselves. On July 30, 1893, Secretary Walpole made a plea in the Oregonian to open a wood yard, which would "[pay] the expenses of the men working in it, and in that way soon make a big difference in the expenses of the association." ${ }^{64}$ Rather than use subscription funds for male applicants, the men would fund the Board's operations through unpaid labor. In 1893, men worked for 3 hours and received two meals and a night's lodging. That year, on average, 70 men worked each day in this fashion. ${ }^{65}$ In

\footnotetext{
62 Board of Charities/Associated Charities Correspondence 1889-1914, Public Welfare Commission, Box 103/18, State of Oregon Archives, Salem, Oregon.

63 "Tramp, Tramp, the Boys Go Marching" Oregonian. Oct. 2 1890. 5

64 “Numerous Applications for Assistance - The Secretary's Suggestion." Oregonian. July 30, 1893. 8

65 "Systematic Work: How the City Board of Charities Is Conducted" Oregonian. December 29, 1893. 3
} 
1894 , the CBC proposed to increase the amount of time required for work to six hours, so that the hobo, or any man afraid of work, could be easily identified. ${ }^{66}$

Also in 1894, the CBC created a wood yard and coal shed specifically to "test" their applicants. ${ }^{67}$ The purpose of this test was twofold. First, it allowed the CBC to obtain free labor in exchange for food, the products of which were sold by the $\mathrm{CBC}$, allowing the organization to remain financially solvent. Second, it theoretically discouraged vagrant populations from entering the city. $\mathrm{CBC}$ officials believed that word would quickly spread among transients that Portland was not a town in which you could get a free meal, and transients might pass it by. Given the steady population of the North End district, it seems that these work tests did not have the desired impact.

Portland residents were at least somewhat aware that the wood yard was detrimental to the working poor in Portland but it was considered a necessary evil. An article appearing in the Oregonian in 1894 discussed the policy, saying "while this method released a man or two from regular employment, it provided food and shelter for quite a number of applicants for relief." ${ }^{68}$ By 1903, the wood yard had been traded for the rock pile and roadwork, similar to the work forced on prisoners of the county. There was, it seems, little distinction between a man asking for aid and a man who had committed a crime in the eyes of the City Board of Charities. ${ }^{69}$

\footnotetext{
66 "The Unemployed: Their Ranks Are Beginning to Thin Out." Oregonian April 1, 1894. 5

${ }^{67}$ Sawyer, "From Whitechapel to Old Town." 197

68 "Helping the Needy" Oregonian March 3, 1894. 8

69 "Must Move for Saloon: City Board of Charities Finds New Location." Oregonian November 16, 1903
} 
In 1908 , the secretary of the CBC responded to a query for able-bodied men, and provided a description of the labor tests that were a consistent part of receiving aid from the Board.

We have been caring for about 200 men a day who work for meals and lodging among them are many good faithful workers - men who will work as these men are doing in the rain rather than beg are men who can be trusted. ${ }^{70}$

But what were these men working for? They did not receive a wage, instead they received food and lodging and occasionally clothing or shoes so that they could continue to work. If the $\mathrm{CBC}$ could not (or chose not to) remove them from the city or find them paid employment, they could work under the thumb of the $\mathrm{CBC}$ for weeks at a time. Jas Kennedy, mentioned briefly in a CBC note in 1908, worked at the city's gang for two weeks, in return, he only received shoes. Joe Kilger worked on the gang for three weeks, again acquiring only shoes in addition to meals. ${ }^{71}$ Men like Joe and Jas were not being elevated by the $\mathrm{CBC}$, but rather kept in reserve for the next wave of unskilled labor needs. They were working on city projects, improving the metropolitan area with no pay, and kept just busy enough to avoid vice in the city's North End. Based on these accounts, the $\mathrm{CBC}$ made no effort of improvement in the case of transient males. Men could walk off the job, but that meant forfeiting lodging and food, which, in many cases, was unlikely to be an option. The $\mathrm{CBC}$, in turn, offered local manufacturers and farmers

\footnotetext{
${ }^{70}$ Board of Charities/Associated Charities Correspondence 1889-1914, Public Welfare Commission, Box 103/17, State of Oregon Archives, Salem, Oregon.

71 Board of Charities/Associated Charities Correspondence 1889-1914, Public Welfare Commission, Box 102, State of Oregon Archives, Salem, Oregon.
} 
a stockpile of men hungry for any paying job that would remove them from the perpetual work test offered in the city.

Unfortunately, the jobs available through the $\mathrm{CBC}$ were likely to pay well below standard salaries for seasonal unskilled labor, which was already too low to sustain an individual for an entire year. A gentleman in Troutdale wrote to the CBC in 1904, looking for a farm hand and offering only ten dollars a month and lodging in return. The Independent Warehouse and Milling Company offered jobs doing farm work in 1908 for one dollar a day plus lodging, despite the average wage for unskilled labor being approximately fifty percent higher. ${ }^{72}$ The $\mathrm{CBC}$ eagerly sent men to Wasco, Oregon to fill these positions despite the low compensation.

These dubious arrangements were all too frequent. By 1908, the City Board of Charities was receiving an average of 155 applications each day from individuals requiring food or lodging in exchange for work. ${ }^{73}$ To handle this, the $\mathrm{CBC}$ placed an advertisement in the Daily Telegram asking for those with available jobs to write to the CBC offices. The manager of Albaqua Lumber Company wrote in response that he had shut down his mill because of the drop in lumber prices, but would be able to resume operations if he could pay his men a fraction of the going wage. In the name of charity, this individual writes,

\footnotetext{
72 Margo, Robert A., "Hourly and weekly earnings in selected industries and for lower skilled labor: 18901926." Table Ba4314-4319 in Historical Statistics of the United States, Earliest Times to the Present: Millennial Edition, edited by Susan B. Carter, Scott Sigmund Gartner, Michael R. Haines, Alan L. Olmstead, Richard Sutch, and Gavin Wright. New York: Cambridge University Press, 2006.

${ }^{73}$ Board of Charities/Associated Charities Correspondence 1889-1914, Public Welfare Commission, Box 104/18, State of Oregon Archives, Salem, Oregon.
} 
This is an experiment with us having at all times closed down our mills when we could[n't] pay the wages that was considered current but if by paying these wages we will be helping some worthy people we can and will continue operations... Please impress upon the men that the fact that they are working cheaper will not warrant them to do less work. We will expect just as much work as when we pay higher wages and expect this and will enforce the demand. ${ }^{74}$

The $C B C$ responded that there were at least 900 unemployed men in the city that would be able to meet his needs. The men who were sent to Albaqua would have paid 25 cents per meal, leaving them only one dollar each day as take home pay for skilled labor positions. These were the types of jobs available to those that applied through the City Board of Charities.

In 1915 the Oregonian wrote about the nearly 1,000 unemployed or underemployed men at Troy Hotel, 95 percent of which, according to J.C. English, president of the Portland Rotary Club, wanted to work. Like earlier proponents of scientific charity, English suggested that aid was not the answer, but employment. English believed it was largely a matter of mental attitude and depression or economic hardship did not excuse unemployment. ${ }^{75}$ The 1,000 unemployed men did not signify to the upper class Portlanders anything but a lack of industry. However, while claiming that the key to success was merely mental attitude, the $\mathrm{CBC}$ was supplying laborers at half cost or free, leaving few, if any, jobs in the city for laborers that paid a living wage. The $\mathrm{CBC}$ reinforced class distinctions, creating a system of subservience among wage laborers and actively preventing, rather than encouraging, elevation out of this

\footnotetext{
${ }^{74}$ Board of Charities/Associated Charities Correspondence 1889-1914, Public Welfare Commission, Box 102, State of Oregon Archives, Salem, Oregon.

75 "Idle's Problem is Heard." Oregonian, February 7, 1915. 9
} 
substandard way of life. ${ }^{76}$ At the same time, the $C B C$ maintained the status quo for city elites. They created a ready work force for unskilled labor positions while simultaneously absolving the city of the need to care for them.

\section{The Availability of Aid for the Transient Male}

It is clear from City Board of Charities correspondence that there was skepticism among the middle and upper classes regarding the plight of itinerant laborers in Portland at the turn of the century, but it is incorrect to assume that no one received aid. Work tests would have created a cycle of poverty among the laboring class, but food and lodging was also distributed to those willing to participate. The jobs that the CBC provided to laborers often paid less than other comparable jobs, but it was still employment. Unfortunately, the $\mathrm{CBC}$ was more willing to withhold aid from the deserving than to give aid to those who were "imposters." This resulted in large populations of unemployed men who were ineligible for assistance.

In the winter of 1892, Thomas Strong believed that the CBC alleviated poverty for all of Portland's citizens, but that it was a battle the agency was slowly losing due to the constant influx of laborers and poor during the winter months.

The poor that are always with us are now re-enforced by a great many laborers and poor people from Puget Sound and other points, who have flocked here for work and help... The city is too rich and prosperous to let any one suffer within its gates. $^{77}$

\footnotetext{
${ }^{76}$ Cumbler, "The Politics of Charity." 104

77 "City Board of Charities - Laborers and Poor People Flocking into the City." Oregonian. January 9, 1892.
} 
This statement shows the delineation that was being made in charitable organizations throughout the country. The ones who deserve the help, stationary residents of the city with strong community ties and hope of elevation, received aid. The floating men, however, only acted as a hindrance in this lofty purpose.

The greatest risk, as the officers of the $\mathrm{CBC}$ saw it, was offering aid to a professional tramp, one who refused to work and instead relied on charity, trickery, or even theft to survive. On July 23,1889 , the Oregonian described one of these tramps who, at the suggestion that he saw wood for a meal and lodging, flew into a rage, denouncing the City Board of Charities. In response the Oregonian wrote,

The City Board of Charities apparently is not much of a haven for professional tramps, dead beats, and beggars. It does not exist for this class of people, and is 'not at home' when they call. Honest and worthy applicants always receive the most kindly consideration. ${ }^{78}$

The City Board of Charities used these stories to justify the lack of aid to itinerant males. It was better to be conservative with aid than risk of giving aid to the wrong person. In May of 1912 the Portland CBC was asked to verify a claim made in Seattle. Anton Huber, a migrant railroad worker, requested aid in Seattle after a steel splinter lodged into his eye. He claimed his employer refused to keep employing him following the injury. The Portland Board of Charities contacted the railroad company to verify this story, which the railroad company refused to do, stating instead that Huber did not return to work after his grievous injury. He was likely refused aid in Seattle once the Portland $\mathrm{CBC}$ reported on its findings regardless of whether or not the railroad's account

\footnotetext{
78 "What! I Saw Wood? - A Caller at the City Board of Charities Flies Into a Furious Rage When Offered Work" Oregonian July 23, 1889. 8
} 
of events could be verified. A gentleman named J.C. Harwich, whom Portland resident Benjamin Young had sent to the Board for assistance, faced similar treatment. Staff at the City Board of Charities wrote, "J.C. Hardwich whom yo [sic] sent to this office today, is we fear a professional. ${ }^{\prime 79}$ The reason for this assessment appears to be that he would not saw wood unless he was paid to do so.

Such stories illustrate the skepticism with which the CBC viewed unemployed men. If the Board helped a "professional" tramp, it would be condoning idle behavior, which could expose the social fabric of the city to exploitation by the underclass. Men who came into the $C B C$ offices and were not given assistance by the $C B C$, therefore, were not counted as a failing, but rather a success. The City Board of Charities published reports in the Oregonian detailing how many were helped and how many were turned away using three categories: "deserving," "doubtful," and "undeserving." Men like J.C Hardwich would have fallen into the "undeserving" category, doubtful applicants were likely to require more investigation before aid was given, and "deserving" applicants were helped immediately.

${ }^{79}$ Board of Charities/Associated Charities Correspondence 1889-1914, Public Welfare Commission, Box 102, State of Oregon Archives, Salem, Oregon. 


\begin{tabular}{|l|l|l|l|l|l|l|l|}
\hline \multicolumn{9}{|c|}{} & \multicolumn{6}{l|}{ Aid Given to all Applicants (men, women, children) } \\
\hline Year & $\begin{array}{l}\text { Number of } \\
\text { Applicants }\end{array}$ & $\begin{array}{c}\text { Unmarried } \\
\text { Male } \\
\text { Applicants }\end{array}$ & Deserving & Doubtful & Undeserving & $\begin{array}{c}\text { Given } \\
\text { Permanent } \\
\text { Job }\end{array}$ & $\begin{array}{c}\text { Given } \\
\text { Temporary } \\
\text { Job }\end{array}$ \\
\hline 1891 & 1,970 & 1,208 & 587 & 542 & 250 & 289 & 474 \\
\hline 1892 & 1,500 & 925 & 289 & 562 & 180 & 84 & 344 \\
\hline 1893 & 2,091 & 1,288 & 570 & 745 & 190 & 57 & 1,087 \\
\hline 1894 & 3,117 & 2,450 & 1329 & 1,610 & 178 & 163 & 2,756 \\
\hline
\end{tabular}

Table 1: Annual Board of Charities Report as Listed in the Oregonian ${ }^{80}$

From 1891-1894, the Annual Report of the City Board of Charities was published in the Oregonian, detailing who asked for and who received aid. During this time period, unmarried men made up over half of those who requested assistance. On average, 4050 percent of the total number of applicants, male and female, applying for assistance were either denied aid or considered "doubtful" and examined further. The CBC did not break down the dispersal of aid based on gender, but, using this average and assuming that unmarried men were just as likely to receive aid as women, at least 1,500 of the 3,117 men who asked for assistance were unlikely to receive it in 1894 . However, looking through $\mathrm{CBC}$ correspondence, it is likely that married men, women, and children would have received a larger percentage of aid than unmarried men. Therefore, the number of men helped was likely significantly lower than 50 percent of applicants.

The Annual President's Report of the City Board of Charities declared in 1890 that "the imposter class has almost disappeared . . . the tramp element has learned at last

\footnotetext{
80 "Board of Charities" Oregonian December 15, 1891. 6; "Charitable Work" Oregonian March 24, 1893. 8; "Board of Charities" Oregonian November 28, 1893, 6; "Help for the Needy" Oregonian November 27, 1894,10
} 
the character of our Board and has left us clear to provide for the really needy and the worthy poor." ${ }^{\prime 1}$ In 1893, President Strong reiterated his point saying,

If there is a man, woman or child now suffering in Portland for clothes, food, fire or shelter, they must be doing so voluntarily. The county has plenty of resources. The city board has means, and the hungry are fed and the poor are relieved as soon as we can find them. ${ }^{82}$

A review of the $\mathrm{CBC}$ during the same period reveals that the President's statement is untrue. What President Strong described as the "tramp element" was alive and well in the city of Portland well into the twentieth century. What institutions like the City Board of Charities accomplished was moving these individuals to the fringes, into the prisons, saloons, and brothels that became an alternate means of survival when offering oneself as a supplicant to charitable institutions was no longer a viable option.

Scientific charity in the city of Portland served as a means of classification and exclusion of certain types of poor, which in turn diminished the ability of the hobo population to move above their station through equitable wages, education, or basic assistance in the winter months. In addition, by forcing the transient male population into vice districts by denying them aid, the city was in a position to either remove or retain them forcibly through arrest and incarceration. The $\mathrm{CBC}$ created a means for the City of Portland to offer superficial assistance without challenging the economic systems for the elite upper classes or the mythology of Portland as a city of wealth. As Strong argued in 1893, true Portlanders were all elevated; those left on the streets were there

\footnotetext{
81 "City Board of Charities Annual Meeting Held." Oregonian December 20, 1890

82 "Information Wanted: Board of Charities Wishes to know of all cases of Destitution." Oregonian January $27,1893.4$
} 
because they were unwilling to meet the standards of the American West, which rewarded hard work and perseverance. 


\section{Chapter Three \\ Portland Takes an Official Stance on the Hobo Menace}

"There is no question of being out of work here. If a man stands around the streets, and is noticed as habitually doing so, he is cautioned by the police; and if he persists in doing this he will be arrested, and, if he cannot show enough money to keep him, off he goes to the rock pile for a few days or weeks ..."1

- Harold Farrow, 1910

Portland's charitable approach to itinerant laborers as outlined in the previous chapter is a reflection of an upper middle class understanding of poverty. The City Board of Charities, funded largely through contributions of the Portland elite, is a manifestation of these views. Portland's political response was similar, in that it reflected the views of powerful officials and businesses more readily than reformminded progressives. Unfortunately for the itinerant male, this resulted in strict punishments against them and willful ignorance towards institutions of vice that exploited poorer populations. Like charitable organizations, it became the policy of Portland to punish the symptom of labor inequalities and largely ignore the disease itself. This policy allowed Portland to maintain a transient labor class while claiming no responsibility in the poverty of the men upon which their prosperity depended.

\section{A Public Menace}

The position of city officials on unemployed laborers in Portland at the turn of the century alternated between disdain and willful blindness. The relationship between

\footnotetext{
${ }^{1}$ Alan Sykes, "Harold Farrow's Splendid Portland, 1910," Oregon Historical Quarterly 99, no. 1 (April 1, 1998): 48-61. 60
} 
the law and migrant populations over time moved from neglect, to abuse, to exploitation. Charitable efforts created a means of systematized exclusion, unlawful work camps, and methods to remove the populations to other towns. The city of Portland as an official entity acted as an extension of this culture of ignorance, by employing strategies of exclusion, expulsion through laws, and police action. As late as 1908, municipalities all over the country believed that government agencies had no place in the affairs of the unemployed who congregated in their cities. Only in cases in which the poor could not help themselves through age or infirmary or if a law was broken did the government become involved, typically not on the side of the unemployed laborers. $^{2}$

This policy of ignorance derived partly from the prevailing notion, as exhibited among charitable institutions, that homelessness in all its forms was a sign of hereditary weakness. At the turn of the century, city or state involvement in the affairs of the homeless had little or no impact, since municipalities believed they could not change the essential character of the homeless themselves. ${ }^{3}$ Francis Wayland, the Dean of Yale Law School from 1873-1903, illustrates this disdain for the transient class and their inability to be elevated,

As we utter the word Tramp . . there arises straightway before us the spectacle of a lazy, shiftless, sauntering or swaggering, ill-conditioned, irreclaimable, incorrigible, cowardly, utterly depraved savage. ${ }^{4}$

\footnotetext{
${ }^{2}$ Sawyer, "From Whitechapel to Old Town." 230-231

${ }^{3}$ Ibid. 311

${ }^{4}$ DePastino, Citizen Hobo. 4
} 
The role of the city, therefore, was to protect the interests of the rooted populations and simply contain or expel those who were deemed unworthy. It is important to note, however, that this exclusionary legislation followed gendered lines. In Portland, women and girls who were susceptible to vice and unemployment received assistance through state and local protective agencies, as well as more options through charitable organizations for assistance and social reform movements that fought exclusively for women's rights. ${ }^{5}$ Men were not afforded the same level of assistance.

While hereditary weakness was given as the cause of homelessness by charitable organizations, psychologists studying the urban experience believed modern life itself contributed to the hobo menace. These individuals linked the influx of the hobo populous to the movement from rural to city life.

Density of population, the disposition to herd together in large cities, tenement occupation, the tightly drawn lines of social distinction and contact, the affinity of money for itself whereby the rich constantly grow richer and the poor poorer, the combinations of capital in every conceivable way, producing and reproducing at will without demand, and refusing to produce if profit accrue therefrom, the legislation, State and National, effected by greed and monopolistic desire - all tend to make the Tramp, and like the famed Frankenstein, when once created he cannot be unmade. ${ }^{6}$

The hobo was not a product of a boom-bust markets, or a byproduct of a need for casual labor in the American West, but rather a result of modern life itself. Psychological arguments regarding hereditary weakness combined with those of social Darwinism and the demands of the modern marketplace created a class of people who would occupy the bottom rung of society. Using these two schools of thought, Portlanders believed

\footnotetext{
${ }^{5}$ Myers, A Municipal Mother. 3, 28

${ }^{6}$ Bruns, Knights of the Road. 67-68
} 
there was no municipal responsibility to address the issues of poverty with changes in legislation, workers' rights, or wage increases. Consequently, laws regarding the hobo menace in Portland dealt with migrant laborers only to expel them, contain them, or force them to work.

Populations of itinerant males were considered a threat to municipalities for a variety of reasons, both legitimate and perceived. The hobo class was thought to be more likely to be involved in vice activities, such as drinking, gambling, and prostitution. These actions led to moral weakness, sexually transmitted diseases, and acts of violence. On a more fundamental level, scores of homeless men were a threat to the reputation of the city, one in which poverty and destitution was not thought to exist. Just as Thomas Strong declared that all homeless were helped through the CBC, Portland officials wished to create the image of a city without the negative trappings of urbanization of which the hobo was a persistent reminder.

\section{Laws and Police Actions on Vagrancy}

Vagrancy laws were already prevalent in the United States by the turn of the century, and were based on similar statutes that were present in Great Britain and elsewhere since the seventeenth century. By 1898, only four states lacked legislation geared towards issues of vagrancy. These laws were deliberately ambiguous, allowing police to enforce them against nearly anyone who was considered a public nuisance. Pennsylvania, for example, defined a tramp or vagrant as anyone who "can give no 
reasonable account of themselves." ${ }^{7}$ Laws in some states elevated issues of loitering and begging to felonies, where they were, in previous decades, only misdemeanors. ${ }^{8}$ Punishment could, therefore, be quite extreme for a conviction. In Connecticut someone convicted of vagrancy could be sentenced by the authorities to as much as three years of hard labor. ${ }^{9}$ In other jurisdictions it was common to sentence those convicted to anywhere from 30 to 60 days in a labor camp. ${ }^{10}$ Depending on local laws, an unemployed male merely entering into a town faced arrest, forced labor, or chain gangs. The reoccurring thread among all cities' vagrancy laws was a healthy dose of disdain for transient laborers. As early as 1877, editorials in the Chicago Tribune suggested "putting a little strychnine or arsenic in the meat and other supplies furnished to tramps ... a warning to other tramps to keep out of the neighborhood." 11

Vagrancy laws were not only a punishment, but also a deterrent to laborers who were searching for a city to occupy for the winter. Proponents of harsh vagrancy laws believed that towns with lenient laws, or towns that provided housing, even in the city jail, would attract more transient males. This led to ever increasing sentences for vagrancy as towns across America looked to discourage the migrant class from settling inside their city limits. In Portland, the public regularly cried out for stricter punishments, longer prison stays, and an end to any municipal housing. The need that

\footnotetext{
${ }^{7}$ Wyman, Hoboes. 718

8 Ibid. 722

${ }^{9}$ DePastino, Citizen Hobo. 38

${ }^{10}$ Cresswell, The Tramp in America. 906, 923

${ }^{11}$ DePastino, Citizen Hobo. 4
} 
the city had for a transient labor force was completely divorced from its treatment of that labor force during winter months.

The hobo class, in Portland as in other municipalities throughout the country, was often arrested on charges of vagrancy, a sort of catchall that could apply to any undesirables within city limits regardless of any actual criminal offense. That is, to be arrested, transient laborers did not have to beg, or be drunk, or engage with a prostitute. If a transient was simply in Portland without a visible means of financial support they could be arrested. The modern iteration of Portland's vagrancy law was enacted on March 28, 1885 as Ordinance Number 4549. It states as follows:

Section 1: Any habitually idle or dissolute person who has no visible means of living or lawful occupancy or employment by which to earn a living or any person who shall be found begging the means of support or who not having other lawful means of living refuses to work or who shall habitually wander about the streets without any lawful [illegible] or who lives in or about any house of ill fame or bawdy house is hereby defined to be a vagrant.

Section Two: Any person who shall be committed before the Police Judge of being a vagrant as defined in Section One of this ordinance shall be fined not less than twenty five dollars no more than one hundred dollars or be imprisoned in the City Jail not less than ten no more than ninety days.

Section Three: It shall be the duty of the Chief of Police and all policemen to prosecute any person whom they shall record of their own [illegible] or by reliable information to be a vagrant as defined by this ordinance.

Section Four: Ordinance Number 2995 entitled "An Ordinance defining vagrancy and providing for the punishment thereof" approved February $4^{\text {th }} 1881$ and all ordinances or parts ordinances [that] conflict herewith are hereby repealed.

Approved March 28, 1885. Passed the common [council] March 26, $1885^{12}$

\footnotetext{
${ }^{12}$ City Auditor - City Recorder - Council Ordinance - 4549 - An ordinance to define and punish vagrancy. Container B/24274, Record Number AF/47532. City of Portland Archives, Portland, Oregon.
} 
Portland's vagrancy law is notable for three reasons. First, it allowed for the arrest of anyone who seemed to be without work, rather than for a specific action. Second, those accused of vagrancy did not have the option to appear before a jury, instead the Police Judge convicted and passed sentence at once. Third, the fine was steep given the average wage of an unskilled laborer and the time spent in prison was up to three months, with sentencing at the complete discretion of the presiding judge. Enforcement of this ordinance relied heavily on the classification of a tramp, an individual's appearance and mannerisms, and the preconceived notions of the deserving and undeserving poor. In essence, the police force of Portland had the blanket authority to enforce these rather malleable distinctions and commit a man to a sentence of forced labor for merely looking like a tramp. The creation and use of vagrancy laws operated as a solution to the urban issue of the anonymous and mobile poor. The charge did not require investigation into circumstance, only the superficial observation of a stranger.

Every indication suggests that police used this vagrancy law, and other charges at their disposal, to attempt to contain the hobo population of Portland. In 1889 , the arrests of those likely to be transient males were as follows: Drunk: 1,272 , drunk and disorderly: 366, disorderly: 383, roaming the streets: 137, vagrancy: 102 and begging: 75. In addition to those formally charged, there were also individuals who "prefer a night's shelter with the prisoners to the risks of being arrested for vagrancy or for 
roaming the streets after midnight." In the winter months, those availing the city of lodging in the police station numbered as high as 484 people in one month. ${ }^{13}$

A swift conviction, without the benefit of a jury, was not unusual in the late nineteenth century. Jack London famously recounted his arrest in The Road, which occurred in Niagara Falls in June of 1894.

In the courtroom were the sixteen prisoners, the judge, and two bailiffs. The judge seemed to act as his own clerk. There were no witnesses. There were no citizens ... to look on and see how justice was administered in their community. The judge glanced at the list of cases before him and called out a name. A hobo stood up. The judge glanced at a bailiff. "Vagrancy, your Honor." said that bailiff. "Thirty days," said his Honor. The hobo sat down, and the judge was calling another name and another hobo was rising to his feet. The trial of that hobo had taken just about fifteen seconds. ${ }^{14}$

According to articles in the Oregonian, the Portland system of handling vagrancy trials was similar to London's account. Records of vagrancy arrests can be found in police reports published in the Oregonian, but give only a rough outline of the procedures associated with these arrests. However, the variability of the sentence and the seeming swiftness with which the courts handed down that sentence is striking.

Hank White, labeled a hobo in 1891, was given 30 days in the city jail for a charge of vagrancy. ${ }^{15}$ John Schmeiser, a "face very familiar in the police court," was tried and convicted in 1894 for begging by the presiding judge. The sentence was 80 days in jail. ${ }^{16}$ In 1896, “Eight men of the 'hobo' kind were arraigned on charges of trespassing, and were given ten to thirty days. The other offenders were simple drunks and

\footnotetext{
13 “Chief Parrish's Report." Oregonian January 6 1890. 5

${ }^{14}$ London. "The Road" Peregrine Press, New York 1907. 77

${ }^{15}$ Oregonian, May 28 1891. 10

16 "Two Kinds of Begging." Oregonian. August 18, 1894. 5
} 
nightwalkers, and their cases were quickly disposed of.." ${ }^{17}$ Gus Gale, also arrested on vagrancy in 1896, was sentenced to 60 days in jail by the court. ${ }^{18}$ On October 18,1892 , the record of arrests and convictions written in the Oregonian simply stated, "there were about a dozen drunks and vags disposed of in the usual manner.,"19

The trials of these men relied on drawing clear distinctions between a man and a hobo. This is illustrated through not only the conviction process, but also in how trials were discussed by the popular press. Oftentimes, those on trial were feminized by reporters, which served as a delineation between the hobo and the "real" man.

Oregonian articles written for the express purpose of highlighting this distinction turned actual Portland residents into comical tramp figures. In a story that is perhaps more satire than reality, the Oregonian details the arrest and trial of Alfred Mackay, 26, a hobo from Pennsylvania who found himself in the city jail. The charges against him were trespassing, he was found sleeping in a barn.

He shambled rather than walked into the Municipal Court, and when he faced Judge Cameron, he uttered these words: "I'm tired." In the course of crossexamination he spoke so slowly that his listeners got nervous, but opinion seemed to be divided whether the man was the slowest person who ever came out of the East to visit Portland, or whether he is simply a clever actor.

The Judge asked to see Mackay's hands, decided that Mackay hadn't worked a day in his life, and chose to sentence him to immediately leave town, rather than clog the prison with him. The Oregonian's treatment of this hobo, perhaps the most detailed account of a trial that was given to their readership during this time period, alternates between

\footnotetext{
17 "Court Notes" Oregonian February 15, 1986. 10

18 "In The Municipal Court" Oregonian October 21 1896. 6

19 "Police Court Loungers" Oregonian October 18, 1892.6
} 
amusement and disdain, admitting that Mackay might be a clever tramp, but also referring to his speech as "effeminate tones," and pointing out his small, un-callused hands, which called his manhood into question. ${ }^{20}$

MacKay's portrayal was common. In 1902, Frank Watson, another "Weary Willie" was said to have demanded a small hammer if he was sent to the rock pile, as he did not believe he would be able to swing a sledgehammer. Watson, perhaps because he had recently been employed as a tailor, was sentenced only to five days behind bars. ${ }^{21}$ K.C Baker, another migrant laborer, was completely dehumanized in the public press, according to the reporter he,

Unquestionably looked like a prize that should be preserved in alcohol by the Smithsonian Institution. His tangled, excelsior-like hair crept in tangled masses to his shoulders and there was a fragment of straw cropping out and bespeaking of nights in the straw-stack. A long, carrot-like protuberance, evidently a nose, crept out from a maze of tangled hair on his face, and was the only feature discernable. $^{22}$

The judges who presided over these vagrancy cases echoed the views of the Oregonian and local charitable organizations. They believed that a real man should work to support himself; therefore the individuals charged with vagrancy were, according to contemporary accounts, not real men. In fact, in some depictions, they were hardly human. A hobo given only the name F. Rogers was arrested in August of 1905. Municipal Judge Cameron oversaw his case. After interrogating Rogers, Cameron said, according to reports,

\footnotetext{
20 "Genuine Weary Willie" Oregonian October 25, 1901 page 8

21 "Give Me a Small Hammer, He Says" Oregonian January 3, 1902. 7

22 "In the City's Trouble Shop." Oregonian September 7, 1904. 14
} 
What is the matter with a young man like you, who is able and there is plenty to do, that you do not work? It is remarkable, in my estimation, for a man of your strength and health to roam about, doing little or nothing and living the life of a hobo. Your clothes are the worst ever; your shirt is so filthy it is not fit to be seen. It would make a hog sick to have to associate with you, in your present dirty condition.

Rogers was sentenced to jail and forced labor as a means of determining whether or not he was in fact willing to work. ${ }^{23}$ Cameron continued his crusade against the hobo class when, in 1906, a dozen hobos were rounded up from North End establishments.

Judge Cameron was particularly disgusted with Martin Lamb. Aged 23, and hailing from Tacoma, according to his story. He was pressed for some history regarding his recent movements, and said he worked through December in Tacoma and earned \$14. 'Do you think \$14 is enough for a month's work?' asked Judge Cameron. 'Well, it helps some,' replied Lamb. 'It is disgusting to see a man like you' said Judge Cameron, as he stern faced Lamb. 'Your clothing is dirty and you are dirty; you have no money, no ambition to get any. There is work all around, but it is evident you do not desire to run into any of it. If we had a rockpile, I would send you to work on it for 90 days, but we have none. As we cannot use you here, and you will not work if permitted to remain, I will give you two hours in which to leave Portland and if you are found here after that, you will have to serve 90 days in jail. ${ }^{24}$

William Pinkerton, of the Pinkerton Detective Agency, came to Portland to inspect one of his local operations. The Oregonian quoted him saying that the yegg man or hobo criminal was the biggest threat to the law currently facing the country, replacing the more "high-toned" crook of earlier eras. Pinkerton's suggestion? The whipping post:

The whipping post would help to male the yeggman's business unpopular, and I'm in favor of adopting it all over the country. Give these fellows a whipping in public as they do in Delaware. There a criminal is whipped in a public place and sentenced afterward. Every blow brings the blood and leaves a reminder. There

\footnotetext{
23 "Back to Jail, Then To Work." Oregonian. August 13, 1905. 36

24 "Orders Vagrants to Leave Town." Oregonian. January 6, 1906. 12
} 
is less crime in Delaware than any other state in the Union in point of population. Tramp crooks are afraid of the lash and emigrate. ${ }^{25}$

Pinkerton's stance on homeless men in Portland comes from rampant anti-labor motives consistently perpetuated by Pinkerton agents. Acting as a private police force to break strikes, Pinkerton agents personified the labor/business divide that led business leaders, including those in the Portland metropolitan area, to dig in their heels against workers' rights movements. ${ }^{26}$ Pinkerton's suggestion of the whipping post for the hobo criminal was simply a continuation of the violence already condoned by Pinkerton for other types of laboring men.

Vagrancy laws that allowed for indiscriminate arrests of all idle poor combined with cruel treatment at the hands of the court underscore the city's willingness to treat transient laborers as a pestilence rather than men upon which industries of the American West depended. The recounting of trials of hobos in the press further solidified conceptions that these individuals were not men, certainly not Portland men, and they did not deserve to be treated as such. Portlanders who held positions of authority were unlikely to challenge these conceptions because it was more beneficial to blame the man and not the institutions. The arrest of a transient male, however, was merely the beginning of the dehumanizing system put in place to quell the hobo menace.

\footnotetext{
25 "Are Fashions in Crime? William A. Pinkerton Talks of Detective Business." Oregonian November 5, 1903. 5

${ }^{26}$ Robert P. Weiss, "Private Detective Agencies and Labour Discipline in the United States, 1855-1946," The Historical Journal 29, no. 1 (March 1, 1986): 87-107. Pg. 4
} 


\section{"Free" Housing: Oregon's Prison System}

While a massive reform movement led by Progressives would work to improve the prison system within the next two decades, prison officials at the turn of the century regularly subjected the tramping classes to acts of torture and ill treatment while serving their sentence. Inadequate food, lacking sanitation, and crowded cells were commonplace, but more disturbing were suggestions of forced sterilization, or even death. Believing that vagrancy and wanderlust were actually hereditary anomalies, scientists and reformers alike suggested that the option of procreation should be removed, or, worse, that the individual should be sentenced to a "gentle, painless death." ${ }^{27}$ In Oregon, a shackle known as the Oregon Boot was used to subdue prisoners through World War I, despite proof that wearing a heavy weight for any extended period of time would permanently cripple the occupant of the device. ${ }^{28}$ Sterilization, disfigurement, and death were all very real threats to prisoners in the nineteenth century and this was the prison system that awaited those arrested and convicted on vagrancy charges.

From 1890 to 1915 , were ideological conflicts in Oregon politics between the conservative Republican faction and more reform-minded Democrats, who took turns at the helm in the late nineteenth- early twentieth centuries. Starting in the 1880's, the Republican Party in Oregon was controlled by railroad, timber, mining, and banking

${ }^{27}$ Cresswell, The Tramp in America. 2232, 2225

${ }^{28}$ Ward M. McAfee, "The Formation of Prison-Management Philosophy in Oregon, 1843-1915," Oregon Historical Quarterly 91, no. 3 (October 1, 1990): 258-84. 260 
interests that were largely unsupportive of itinerant laborers. ${ }^{29}$ Republicans at the state level dismissed reform policies and favored discipline and security, rather than prisons as areas of potential uplift and rehabilitation. ${ }^{30}$ A.N Gilbert, Prison Superintendent from 1895-1899 said that a released prisoner was only a "worthless tramp-vagabond" who did not deserve or require state funds or assistance. ${ }^{31}$ In Portland during this period, reform minded individuals commented on substandard treatment of prisoners, but did very little to alter policies that allowed for this poor treatment. State officials believed that less severe punishment would result in more unemployed populations in the city. This belief allowed substandard treatment to continue in Oregon prisons.

Many of the men who ended up in prison were arrested, charged, and convicted, but other migrant laborers chose prison over a night on the street. Charitable organizations were unreliable in their support and often required work tests before giving any aid whatsoever, so, in Portland, as in other cities, the central police station became a viable option for those with no housing or food. ${ }^{32}$ The fact that men willingly committed themselves to prisons signaled to the population of Portland that a prison stay was too easy, that these men benefitted from the city that had attempted to punish them. While prisons provided a roof and at least some type of food, these were not the luxury hotels that many of the general public imagined them to be. From 1891 to 1909 , a yearly average of 300 men willingly committed themselves to prisons for

\footnotetext{
${ }^{29}$ Tom Marsh, To the Promised Land (Oregon State University Press, 2012). 78

${ }^{30}$ McAfee, "The Formation of Prison-Management Philosophy in Oregon, 1843-1915." 262

${ }^{31}$ Ibid. 265

${ }^{32}$ Sawyer, "From Whitechapel to Old Town." 201
} 
lodging by walking into a police station and asking to be housed, far less that the number of men who likely entered the city as unemployed laborers. This number rose in economic declines, but never met the level of a public crisis. ${ }^{33}$ In other words, a hobo was far more likely to be committed to prison based on an arrest rather than voluntary imprisonment.

While the general population was concerned that the vagrant class was living off of the city, the $\mathrm{CBC}$, not generally a strong advocate for homeless men, was concerned that the prison system in Portland was a violation of prisoners' rights. A report by the State Board of Charities and Correction described the city jail as,

A disgrace to a civilized community and has been frequently condemned by the grand jury of Multnomah county, as well as the Chief of Police who found it inadequate for the proper care of prisoners. ${ }^{34}$

When this report was written in 1892, the city jail was located in the bottom of the courthouse, which was built in $1864 .{ }^{35}$ The jail had a new wing with steel cage cells and older cells in the basement made of stone. ${ }^{36}$ Thomas Strong described the conditions,

For several weeks at a time men are kept in this cell or ward and, instead of being compelled to bathe, they cannot bathe if they would... Many of these prisoners are compelled to huddle at night upon bare bunks around the room or upon the floor ... Several cells have no direct connection to the outside air. ${ }^{37}$

\footnotetext{
33 Ibid. 232

${ }^{34}$ Board of Charities and Correction, Oregon 1892 "For the partial biennial period ending December 31, 1892. 10. Oregon Historic Society, Portland, Oregon.

${ }^{35}$ Jewel Lansing and Fred Leeson, Multnomah: The Tumultuous Story of Oregon's Most Populous County (Corvallis: Oregon State University Press, 2012). 25

${ }^{36}$ Board of Charities and Correction, Oregon 1892 "For the partial biennial period ending December 31, 1892. 126. Oregon Historic Society, Portland, Oregon.

${ }^{37}$ Board of Charities and Correction, Oregon 1892 "For the partial biennial period ending December 31, 1892. 212. Oregon Historic Society, Portland, Oregon.
} 
A case of the wrongful death of a prisoner brought to light the conditions of the city jail for the public. The Oregonian reported, "the cells of the city jail are not provided with mattresses or blankets, as the police think these would prove too much of an inducement for the hobo class." ${ }^{38}$ In a report published in the Oregonian on January 6, 1890, Police Chief S.B Parrish reported that the city jail was "unfit for the needs of the city." He continued, "no doubt the city did not intend that it should be a comfortable lodging house. But even criminals are entitled to fresh air and cleanliness." Rather than addressing Parrish's concerns, the city chose to make only one prison improvement that year,

A new 70-foot wire-bound hose has been purchased for the city jail, and in the future some efforts will be made to test the purifying properties of water. The hose is long enough to reach from the faucet to any cell, and a dirt-begrimed tramp or hobo can get a free bath at a moment's notice. All that is yet required is some good man to handle the hose, and then a few hours might be devoted each day to the work of cleansing the filthy prisoners who at times infest the main cell. ${ }^{39}$

While reformers suggested improvements, the complaints continued. In 1903,

those housed in the Portland City Jail dealt with "overcrowding, a lack of bathing facilities, ventilation, and other unsavory physical nuisances." ${ }^{40}$ In 1908 , Police Captain Moore believed that Portland required a prison able to house 200 individuals to adequately contain undesirables from the city. Because of overcrowding, Moore and his officers released hobos, only to re-arrest them days later for a new charge. While the city had grown, the prison had not. Issues of filth and overcrowding that plagued the

\footnotetext{
38 "Sticks to His First Story" Oregonian July 22, 1899. 12

39 "The Hose Will Come in Handy" Oregonian April 4, 1890. 5

${ }^{40}$ Sawyer, "From Whitechapel to Old Town." 234
} 
prison system in 1890 no doubt only worsened as the city grew. ${ }^{41}$ As late as 1912, Governor Oswald West claimed that the jails in the state of Oregon were "outdated, overcrowded, and ineffective." ${ }^{42}$

Beyond prison conditions, those sent to the Portland City Jail were also at the mercy of fellow prisoners who formed a kangaroo court, common in the prison system at the turn of the century. Ostensibly designed to allow the prisoners to police themselves, kangaroo courts often devolved quickly into demands for money and acts of violence. Despite the knowledge that kangaroo courts were often exploitive and violent, the Board of Charities and city officials approved the continuation of the practice simply because it allowed for fewer staff to maintain order. "It is the opinion of some of the members of the board that the kangaroo court is a good institution if kept well under the supervision of the jailer." ${ }^{43}$

An Oregonian article in 1891 described one form of punishment that was commonly inflected on those who appeared before this unofficial judicial body. "[Cobbing] consists in the infliction of several blows of a paddle on that portion of the anatomy created according to tradition, for such purposes." The article goes on to say, "The discipline of the kangaroo court is mainly very wholesome, enforcing sanitary and other regulations in the jail." ${ }^{44}$ The conditions of the prison combined with the real threat of prisoner-on-prisoner violence that was condoned by the city officials

\footnotetext{
41 “Moore Asks for New City Jail” Oregonian May 30, 1908. 16

42 Myers, A Municipal Mother. 110

${ }^{43}$ Board of Charities and Correction, Oregon 1892 "For the partial biennial period ending December 31, 1892. 141. Oregon Historic Society, Portland, Oregon.

44 “Appealed From the Kangaroo Court" Oregonian December 24, 1891. 5
} 
themselves, suggests that serving time in prison was a final resort of the desperate, or an unfortunate side effect of the life of migratory labor.

\section{Forced Labor: Hobos at the Rock Pile}

At the turn of the century, prisons throughout the country moved from systems of containment to systems of elevation. Just as charities focused on putting work, paid or unpaid, in the hands of idle men, prisons too developed systems of contract labor, in which prisoners were "hired" to work on public projects. Democrats saw this as an ideal alternative to extreme physical punishment that had been common in prisons during the early and mid-1800s. ${ }^{45}$ Prisoners were not paid for their labor beyond the substandard food and housing that they were already likely to receive. Through this system, convicts competed for the few jobs available, while simultaneously forcing free laborers into a position of idleness, which could easily lead to jail time. The majority of states abolished the practice of contract labor by 1890, after complaints from skilled laborers and the unions that supported them, however it was not until the tail end of the progressive era that this practice was abolished in Oregon, once the economic damage had already been wrought. ${ }^{46}$

In Portland, forced labor initiatives manifested in various ways, from prison road crews to landscaping the newly created City Park. The most frequent mention of forced labor of prisoners in Portland, however, was the city rock pile, which was used with some regularity from 1890-1910 and provided gravel for construction and roads.

\footnotetext{
${ }^{45}$ McAfee, "The Formation of Prison-Management Philosophy in Oregon, 1843-1915." 263 ${ }^{46}$ Ibid. 261
} 
Beginning in 1895, those serving prison sentences in Portland had to break rock at the

City Park or work on the prison woodpile. Describing a typical day for a prison laborer, the Oregonian writes,

The work gang is taken out at 9 o'clock in the morning, after breakfast and made to put in six hours' labor, returning to jail at 3 o'clock, when dinner is provided for them. The jail bill of fare is not the most attractive, but those who complain of the fare won't have to stop there after expiration of sentence, unless they break in again. ${ }^{47}$

The implementation of this program was designed by city officials to discourage transient men from coming to Portland due to their assumed hatred of physical labor. A month later, the Oregonian was ready to call the experiment a success, saying that it was only those who were unfamiliar with the forced labor resolution who would dare come into the City of Portland. According to December's article, some prisoners served 6 months on the rock pile, suggesting that, while Portland's vagrancy law called for a maximum sentence of 90 days, the Police Judge used the law leniently when handing down sentences. ${ }^{48}$

By 1896, those serving in the county jail also performed mandatory labor due to the seeming successes being had on the city level.

A rock pile is the abomination of a hobo. When it is once understood by hobos that 60 days in jail for vagrancy or petty thieving means also good hard work during the time of sentence, they will give this city a wide berth. ${ }^{49}$

In 1897, "work on the rock pile by the hobos confined in the city is flourishing at present", suggesting that the population of itinerant laborers had perhaps increased

\footnotetext{
47 "Hard Work for Hobos" Oregonian November 11 1895. 5

48 "Vagabonds Must Labor" Oregonian December 3 1895. 5

49 "No Loafing in Jail" Oregonian December 31, 1896.8
} 
rather than decreased, though the Oregonian held out hope that the program would still have an impact on the vagrant population of the city. ${ }^{50}$

By 1901, the rock pile was discontinued by the city, likely due to lack of use or funding, but it was quickly promoted again when the Chief of Police estimated that 200 hobos resided within city limits. Portland, it seems, fought a reputation as an easy city for the unemployed, something that the rock pile supposedly refuted.

In the course of their walks around Whitechapel saloons and resorts yesterday, Oregonian reporters found many "Weary Willies" standing there to get out of the rain, and they all, without exception, agreed that Portland was what they called 'a good thing' for hobos.

According to this report, hobos "whose only ambitions were those of an animal - to eat, drink, and sleep" admitted to getting arrested for the purpose of having a dry warm place to sleep. The Oregonian concluded that it was the lack of a rock pile, which had not existed in the city for several years at that point, that gave Portland this unsavory reputation. ${ }^{51}$ There is no suggestion that Portland was more or less kind to the transient male than other Western cities, but the concern that Portland would fill with migrant poor pushed the city toward force labor initiatives. By the $28^{\text {th }}$ of that month, a rock pile had been established on $1^{\text {st }}$ and Flanders. Prisoners worked a 7-hour day, everyday. Regarding this forced labor, "if [the prisoner] refuses to work, means will be brought to bear to compel him to work, though what these means are to be will be decided when the exigency arises." ${ }^{52}$ In 1904, the rock pile was discontinued by the city again but was

\footnotetext{
50 "Rock Pile Flourishing" Oregonian November 28, 1897. 5

51 "No Rockpile for Hobos" Oregonian December 3, 1901. 10

52 “Hobos Will Break Rock" Oregonian December 28, 1901. 7
} 
regularly suggested as a solution to the wandering classes who had again inhabited the city for the winter. ${ }^{53}$

In 1906, city prisoners worked at the county jail's rock pile at Kelly Butte, located at Southeast $94^{\text {th }}$ Avenue and Powell Boulevard, which was a "quick and easy solution of the hobo problem." ${ }^{54}$ A 1907 Oregonian article described the rock pile at Kelly Butte in detail. In August, there were 54 inmates breaking rock each day, likely significantly lower than the population that would work there in the winter given the influx of transient laborers into Portland in the winter months. The sledgehammers were 12 pounds and the prisoners were "breaking stone with sledgehammers in the broiling glare, right up against the wall of the quarry that faced the afternoon sun, the men labored under the watchful eye of two armed guards." The rest of the article suggests that the men are handsomely paid for their work, with all they can eat, tobacco on Wednesdays, books to read and clean sheets on which to sleep. Reports such as this kept the city in an outrage over the "good" treatment that the hobos were given and allowed the city to ignore the official reports of inadequacies and cruelty in the city jail. $^{55}$

One of the only city officials speaking out against rock piles in 1906 was Major Harry Lane, who argued that the inmates were, for the most part, suffering physical infirmities that would make it impossible to perform heavy labor. Lane, who served as Mayor from 1905 to 1909, was a Progressive reformer who, Carl Abbott argues, was

\footnotetext{
53 "City Rockpile is Needed" Oregonian December 1, 1904. 14

${ }^{54}$ Lansing and Leeson, Multnomah. 39; "Visit Kelly Butte" Oregonian October 31, 1906. 13

55 "Hot Day on the Rock Pile" Oregonian August 1, 1907. 10
} 
supported by the skilled workers and middle class of Portland, groups who feared both the residents of the North End as well as the elites of the city. ${ }^{56}$ Lane's policies regarding homeless men did not echo the beliefs of the wealthy Portlanders that would have aligned with the City Board of Charities and the Oregonian, but he was also not necessarily a friend to the itinerant male, whom he believed was prone to vice. Lane was proponent of the social-hygiene movement, believing that vice was not merely a moral issue, but a medical issue as well. So, while he believed that the itinerant population damaged the city of Portland, he also believed that they were able to be elevated, which is not a belief that the $\mathrm{CBC}$, the Oregonian, or other members of the city government shared. ${ }^{57}$

Because of this, he did not dismiss forced labor as a policy; rather he suggested lighter work, which would be within the abilities of all inmates to perform, such as growing vegetables. ${ }^{58}$ His opposition is notable because it is the first suggestion by a city official that the population occupying the prisons were not the unworthy poor, men who refused to work for a living, but rather individuals who could not work. This reprieve from Mayor Lane was short lived. It unfortunately did little to change the conversation on hobos as a whole. By 1907, the city was back to contracting with Kelly Butte to send inmates there for work. ${ }^{59}$

\footnotetext{
${ }^{56}$ Abbott, Portland in Three Centuries. 89

${ }^{57}$ Myers, A Municipal Mother. 18

58 "Discuss City Rockpile" Oregonian February 16, 1906. 10

59 "Hot Day on the Rock Pile" Oregonian August 1, 1907. 10
} 


\section{Hobos Made to Move on}

When a hobo faced a judge, whether on vagrancy or another charge, he was likely to suffer one of two fates. Either he would be sentenced to jail time, which, depending on the year of his arrest might include laboring on a rock pile, or he would be asked to immediately leave town. This was such a common practice that the City Board of Charities regularly spoke out against it, fearing that if all cities rapidly discharged hobo populations, they would simply flood cities farther down train lines, of which Portland was one. The Board of Charities asked city officials nationwide to instead handle their own populations or send homeless men back to their city of origin. As early as 1897, there was a citywide interest in arresting or removing hobos, because they believed that their very presence created an increase in crime.

Hobos are being gathered in by the police in numbers now, and as fast as sentences can be imposed for vagrancy or other offenses included in the list of their deeds are being put on the chain gang. The police are unusually active in this respect now, owing to the numerous burglaries recently committed. The drifting hobo element not only brings to a city many criminals, but its presence affords the more desperate crooks a screen for their best work ... Chief Barry has issued strict orders to patrolmen on all watches to arrests and order out of town every person who comes under the hobo class. ${ }^{60}$

By 1907 the practice of forcing itinerant males out of town came under scrutiny.

The Secretary of the Prisoners' Aid Society was “against the 'move-on' method in vogue in the Municipal Court. Instead, mandatory baths and the rock pile would be more effective to contain hoboism." 61 The most vocal opponent of the "move on" method of

\footnotetext{
60 "Hard After Hobos" Oregonian November 1, 1897. 5

61 "Meet in Annual Session - Prisoners' Aid Society" Oregonian November 3, 1907. 10
} 
vagrancy control was Mayor Lane, who convened a meeting of city leaders on the West

Coast to discuss policies related to this migrant population. He said,

The present system of shipping vagrants from city to city and of driving them about is a bad plan and makes criminals of some who might, under better treatment, be made valuable citizens ... I have no sentimental pity for those fellows who will not work and who prefer to be hobos but ... I would like to see co-operation between the officials of the large cities, and hope they will investigate and decide to take interest in some plan that will bring about this end.

He continued by suggesting that the policy of running men out of town may be unconstitutional and was certainly high-handed. He offered instead that the men be rehabilitated through light labor. ${ }^{62}$

Lane's stance against the move-on policy was not just an act of accountability for the men within his city's boundaries, but perhaps more importantly, it was an effort to change the ways of the man to, hopefully, change the man. Mobility defined the hobo population, suggesting that towns hold on to their homeless populations was a method of reforming one of the more troubling aspects of the migrant laborer. Just as prison reformers suggested that a good bath would solve the hobo problem by removing one component of being homeless, Lane believed that this forced movement would only draw these men further into a life of criminal activity.

\section{The Limitations of the Police}

While Portlanders, the public, and civic leaders of the city wanted to see hobos arrested, put to work, or shipped out of town, there was very little interest in addressing

62 "Deal with Hobos" Oregonian January 3, 1908. 11. 
the broader social ills that plagued the North End area of the city. Vice institutions, saloons, lodging houses, and gambling halls remained largely unregulated at the turn of the century, a trend that continued until a citywide vice crackdown in 1912. Occasionally reform-minded mayors attempted to challenge the status quo, but they were overwhelmingly met with roadblocks. Even elected officials that ran on reform platforms simply ignored vice in the city or, worse, attempted to profit from it. It was common for elected officials to throw the blame of vice on the man, and ignore wholly the institutions that thrived upon his patronage. Portland historians suggest that the lack of regulation in Portland's North End is due in large part to those who controlled these businesses. Peter Boag quotes Oregonian editor Harvey W. Scott as saying "the persons most concerned in the maintenance of these abuses are the principal men of the city- the men of wealth on whose patronage the paper relied. It could not afford to alienate them. It would ruin this paper."'63

In 1891, Portland Mayor William S. Mason said, "We lack the power to enforce the laws ... [We have] no control ... over the police force of our city... Our police perambulate the streets day and night and we hear of no arrests for the violations. ${ }^{\prime 64}$ During this period, special officers employed by business owners were charged with policing the North End, leading, unsurprisingly, to few arrests that would in any way threaten business operations. ${ }^{65}$ The mayor's concerns were addressed with a vice probe

\footnotetext{
63 Peter Boag, "Sex \& Politics in Progressive-Era Portland \& Eugene: The 1912 Same-Sex Vice Scandal," Oregon Historical Quarterly 100, no. 2 (July 1, 1999): 158-81. 164

${ }^{64}$ MacColl, Merchants, Money \& Power. 289

${ }^{65}$ Ibid. 329
} 
in 1892 which linked the most powerful families in Portland to saloons, brothels, and gambling institutions. More than 50 individuals were named in the resulting report. ${ }^{66}$ However, this report did not result in any systematized reforms. In fact, the serving Chief of Police was reluctant to make any arrests, going after only those institutions that lacked connections to Portland's elite and that fell outside of the North End district. Establishments in the North End were all but sanctioned by city officials, as that was where vice belonged. ${ }^{67}$

Sporadic raids would continue, such as a raid on prostitution in the spring of 1895 , but large-scale convictions were uncommon and the city, as a whole, was unable to control the happenings of the North End. ${ }^{68}$ It was only when the hobo class ventured outside of this artificial divide that public opinion erupted. The blind eye that the city offered the North End was, in part, a byproduct of the sheer amount of profit to be had through these businesses. In 1898, the city police force began regular patrols, replacing police who were employed through private citizens but this did not substantially increase arrests. ${ }^{69}$ By 1900 with the election of Fred Merrill, who famously defended prostitution and gambling, to the city council, the city decided to allow the North End to continue as it was. $^{70}$

In 1902, newly elected mayor George H. Williams ran on a platform of city beautification and extensive vice crackdowns. Instead of closing down institutions of

\footnotetext{
66 Ibid. 291

67 Ibid. 323

68 Ibid. 323

${ }^{69}$ Ibid. 328-329

70 Ibid. 341
} 
vice, however, Williams required owners of vice district saloons or gambling houses to pay the city in exchange for the ability to remain open. ${ }^{71}$ In 1904 , a newly elected sheriff attempted to remedy Williams's shortcoming by cracking down on gambling in the North End. ${ }^{72}$ Sheriff Tom Word proceeded to shut down all gambling institutions in Portland, resulting in $\$ 5,000$ in lost revenue for the city and 700 people who were now unemployed. This crackdown only forced vice institutions to relocate or rebrand and did little to curb gambling, drinking or prostitution long-term. It did, however, clean up the North End long enough to maintain a conservative city image during the 1905 Lewis and Clark Exposition. ${ }^{73}$

Lax enforcement of vice laws created Portland as a haven for tramps, according to journalists. Journalist Burton Hendrick wrote,

Even on the Pacific Coast, Portland enjoyed a peculiar fame as a wide-open town. The machine, by a regular system of monthly fees, had practically licensed gambling an prostitution, and under this system of official encouragement the city had become a popular headquarters for all the vicious characters in the Pacific Northwest. ${ }^{74}$

This image of Portland stood in stark contrast to the city that boosters wanted to portray. Just as the hobo's staggering poverty stood in the face of a "land of bounty" image, the North End stood as an affront to the conservative mecca, one of family and settlement, one that Portland boosters so desperately attempted to emulate. However, those that acted as the loudest boosters for the city also tended to benefit financially

\footnotetext{
${ }^{71}$ Lansing and Leeson, Multnomah. 43

72 Robbins, Landscapes of Promise.

${ }^{73}$ Lansing and Leeson, Multnomah. 44

${ }^{74}$ MacColl, The Shaping of a City. 228
} 
from the North End. The continuous implementation of the rock pile was designed to combat this reputation without acknowledging or repairing longstanding institutions that created an itinerant population. Stricter punishments, however, did little to dissuade migrant laborers from entering the city.

The solution to the contradiction, a town of conservatism built alongside a district of vice, was to focus reforms and blame on the transient population that was not of Portland. These vagrants were not of Oregonian stock, as Thomas Condon would define it. Instead, they were a wandering class. They came into thriving communities and brought crime with them. They were a lower quality of person, they were unwilling to work, and they were a drain on the economy. The police actions, the prison system, and the forced labor protocols all focused on the role of the individual over the role of the society in the creation of vice. Rather than hobos acting as a symptom of the problem, they were the problem itself.

Portland's reaction to the hobo was not unique during this time period. Cities throughout the United States reacted to itinerant laborers with similar initiatives. Portland's response, however, ties into a larger issue of the city's view of how it fit into the Western American narrative. Cities, such as San Francisco and Seattle, were towns built on transience, which in turn linked them to vice. Portland attempted to be separate from other Western metropolises. The municipal system for dealing with the hobo population forced these men back into social conventions while also cementing their status as less-than human if they were unable to conform. These men did not warrant a jury trial, a mattress, a fair wage, or the right to live in any town they chose. 
Instead they were hosed down, beaten by fellow inmates, described by officials and the public with words of derision, and forced out on the next train. In 1908, Chief of Police Gritzmacher defended these actions.

Although the average citizen does not realize it, the 'hobo' presents a very serious question to the department. While the sympathy of the average citizen is with the man who is down and out, unless there is some regulating influence on this lower class of society, it becomes man than a mere menace to the welfare of the city. The police are note waging a ware against the unemployed ... We are directing our attention solely to the vicious criminal who hides behind the plea that he can't find work ... We think we are competent to judge between an honest workingman and the hobo. ${ }^{75}$

The city, the laws, and the judges defined these men as a threat to the reputation of the city and then acted on that threat, ignoring that which did not fit into the dichotomy of normalcy and aberration, frontier and settlement. The hobo became criminal by definition; he was stripped of rights and dignities and replaced as a personification of all the vices and misconceptions of an era. Tim Cresswell describes tramps as "pathology in the wider social body. ${ }^{\prime 76}$ It was as this pathology that the hobo was charged, convicted, and punished in the city of Portland.

\footnotetext{
75 "Influx of Hobos" Oregonian January 28, 1908. page 16

${ }^{76}$ Cresswell, The Tramp in America. 2078
} 


\section{Chapter Four \\ Transience in Popular Culture: Hobos Redefine the West}

"The hobo is, in fact, merely a belated frontiersman, a frontiersman at a time and in a place when the frontier is passing or no longer exists."

- Robert E. Park, $1925^{1}$

Sociologist Nels Anderson, a leading expert on the hobo class at the turn of the century and author of "The Sociology of the Homeless Man" published in 1923, noted that the itinerant laborer played an "in-between role related to the two frontiers. He came on the scene after the trailblazer, and he went off the scene as the second frontier

was closing. ${ }^{2}$ In this way, the hobo was neither the explorer nor the settler of Turner's pivotal Frontier Thesis, in which the movement West is seen as a truly American endeavor. Rather, the hobo character was a transient force that embodied simultaneous weakness and masculinity, freedom and imprisonment, the very best and the very worst of the Wild West mythology. This limenal status was seen in the legal system, in which the hobo was not quite a criminal and yet also not quite a citizen, in charity, where he may be both worthy and unworthy, and in popular culture, where the acts of hobos were condemned on page five of the Oregonian while satirized on page eight.

Conceptions of the hobo menace were fluid and often contradictory. Despite attempts to downplay or disassociate the American West from the transient laborer through booster literature, which focused on wealth, conservatism, and abundance, the hobo became an unlikely icon, with implications that reached into standard conceptions

\footnotetext{
${ }^{1}$ Robert E. Park, The City (University of Chicago Press, 1925). 160

${ }^{2}$ Wyman, Hoboes. 606
} 
about American life. Historian Tim Cresswell argues that modern conceptions of identity and knowledge were key in the creation of the hobo, as a man and as a myth.

The tramp was 'made up,' brought into being, by a body of knowledge it was claimed was actually about them. Sociology, eugenics, vaudeville comedy and documentary photography were all prominent novel ways of knowing and representing in the late nineteenth century and each was implicated, instrumental even, in the process by which the tramp was made up. ${ }^{3}$

The hobo became, therefore, like the cowboy and the Indian, both a real and nuanced member of the American West and a caricatured icon of the Western mythology. Citizens turned their heads at hobos on the street on their way to vaudeville shows lauding them. Mothers feared the criminal hobo at the back door while their children planned to ride the rails on vacation trips. The real hobo was a vagrant, a weak willed drunk who plagued the city streets; this man was to be put down or sent away. The imagined hobo was an amusing commentary on modern life and wealth. This fascination caused popular media and stage shows to immortalize them and the general public to confront them in, at times, extremely contradictory ways. Itinerant laborers, in turn, latched on to their own mythos, creating or recreating themselves in the image of their stereotyped persona. They separated from the criminal, the militant laborer, and the idle poor and this icon status helped create room in the Western narrative for the hobo.

Examining this duality and its implications requires a close look at issues of masculinity, popular culture, and the movement towards a wage economy. At the turn of the century, Turner's ideal Western narrative became impossible. The frontier was supposedly closed and American men had no more lands to civilize. It was in this

\footnotetext{
${ }^{3}$ Cresswell, The Tramp in America. 91
} 
moment that the hobo entered popular consciousness. Unfortunately, the changing hobo persona had little impact on the treatment of the itinerant laborer of the early twentieth century. However, it did shape the prevailing understanding of the hobo by future generations, as the degradation of the individual faded to the glowing reminiscences of the hero of the iron horse. It was through popular culture interpretations that the hobo eventually found a home in the American West.

\section{Changing Ideals of Masculinity}

"In those days men were men. They had real verve. No one asked for help; everyone did the job that had to be done. Men in those days were so keen... and so filled with grit. They battled and they succeeded." 4

- C.F Adams, 1893

The psychology of the unemployed laborer and his subsequent treatment was partially rooted in nineteenth and early twentieth century understanding of what it meant to be a successful man. As noted in Chapter 2, the very act of asking for charitable assistance put these men in the "unworthy poor" category, and the focus on whether or not a man was "able-bodied" was language that placed worth in form, strength, and virility. This, combined with the existing belief that a true man was a head of household and a provider, created a situation in which the transient laborer straddled the line between a newly created masculine ideal and a deviant. Physically, in appearance and strength, he was a man and his freedom to travel appealed to those longing for a frontier experience. At the same time, his position of charitable dependence and idle behavior placed him in a feminized role.

${ }^{4}$ MacColl, The Shaping of a City. 173 
This in-between status added to the cultured urbanite's unease with the hobo presence, and was used as a means of defining and excluding him. However, the hobo lifestyle was also hyper-masculine, especially at the beginning of the twentieth century. As in other single-sex communities, these men were supposedly not softened by a feminine presence, they were not forced into labor dependency, and they had an amount of freedom that the middle class American male no longer possessed. Therefore, when thinking about middle class conceptions of the hobo population, it is useful to think of the hobo sitting on the cusp of two different and, at times, contradictory masculine identities. In doing so, one can understand how America's reaction to this group of men can be so apparently disparate in popular culture and in laws and charitable efforts.

Historian E. Anthony Rotundo dealt with this changing conception of masculinity in his work, American Manhood. He argues that, much like gender identity in women, masculinity is a construct that is invented and reinvented in response to individual needs and societal understanding rather than a fixed absolute. ${ }^{5}$ Rotundo argues that masculinity in the United States can be broken into three distinct eras. The first, communal manhood, lasted to the first part of the nineteenth century and focused on community identity and duty to country. Beginning in the mid-nineteenth century, there was a movement towards what Rotundo terms self-made manhood, which allowed for the pursuance of self-interest, market economies, and reliance on individual achievement.

\footnotetext{
${ }^{5}$ Rotundo, American Manhood. 7
} 
Moving into the twentieth century, there was a shift to a more corporeal understanding of the American male, termed passionate manhood, which focused less on intellectual and monetary pursuits and more on manliness through strength, form, and vigor. These categories easily fit into a broader understanding of the United States at these intervals, beginning with the creation of a democratic nation, movement towards a free market economy, and finally, the emergence of a wage labor system in which the idealized self-made man was no longer attainable for the middle classes. ${ }^{6}$ Rotundo notes that these eras of manhood were more applicable to a white middle-class identity than a racially or economically varied subset of the population, such as the transient male. However, these delineations are useful in examining the changing conceptions of the hobo in a middle class environment, such as urban Portland. As previously discussed, transient laborers were problematic to the self-made man identity in Portland. Low wages and inconsistent work kept the vast majority from realizing the goal of self-sufficiency, which the city blamed on personal, rather than societal failings. The language and subsequent policies of the City Board of Charities and political figures at the turn of the century relied heavily on the idea that a man should not be in a position of dependency, without familial ties or prospects for improving one's condition.

One striking way that gender played out in popular culture was through reports of hyper-sexualized attacks by transient males on women, reported with some regularity in the Oregonian and usually accompanied by calls to subdue the "hobo

${ }^{6}$ Ibid. 1-9 
menace." Uncontrolled male sexual desire was a weakness in the Victorian framework of masculinity, but was becoming condoned or even lauded in the twentieth century. During this period, concerns over virility and the fate of the white race became commonplace as men became less tied to physically robust occupations and minorities immigrated into the United States. These acts of overt sexuality and even violence put hobos in a hyper-masculine position and the subsequent hunt and punishment of these men was usually portrayed as society putting down a wild beast, something that was both salacious and perhaps titillating.

Reporting on attacks at the turn of the century, then, served two purposes. First, the hobo was depicted as a threat to the home and maternal sphere, and in turn, middle class successes. Tim Cresswell writes, "Both of these - the sexualized body and the maternal body - are threatened by the tramp at the door." ${ }^{\prime 7}$ These reports were meant to insight outrage in the population of Portland, who would in turn support actions to preemptively punish transient males for potential crimes. In addition, the reported attacks, all of which took place when a transient male came to someone's door, may have worked to discourage individuals from providing food, shelter, or any other form of outdoor relief to these men.

At the same time, these articles helped to address emerging issues of masculinity. By demonizing the actions of the itinerant male, they quelled the urge of middle class men to act on a sense of passionate manhood. They simultaneously played to a newfound interest in animalistic manhood, what historian Kevin White would term

\footnotetext{
${ }^{7}$ Cresswell, The Tramp in America. 1716
} 
"underworld primitivism," defined in part by unchecked aggression. ${ }^{8}$ Underworld primitivism could manifest in something as mundane as a fraternal organization or sporting team, but could also appear in the glorification of violence toward women.

The Oregonian reported numerous instances of sexual attacks, pulled from police reports from all over the country. One such incident was reported in March of 1890, of a girl who was attacked in Missouri. The article goes into explicit detail of her attack saying, "the brute ravished, bound and gagged her, cut off her hair and cut her clothes from her body, inflicting severe wounds." ${ }^{\prime 9}$ A similar story appeared in May of the same year,

A brutal case of ravishment was committed in the suburbs of [The Dalles] Thursday midnight upon the person of an old lady over 70 years of age, it is supposed to have been done by a tramp. ${ }^{10}$

Another article reads, "A tramp entered the house of a Mrs. Hall, about nine miles from [Newman, CA] yesterday, and bound the lady with cords and outraged her."11

In 1908, an article appeared of a violent act committed on the streets of Portland, rather than in the home,

This man was a hobo, of repulsive appearance and had accosted two little girls in front of 353 North Fourteenth Street. He tried to entice them away with him, but his effort was noticed by passersby and a strange man divining his purpose, gave chase. $^{12}$

\footnotetext{
${ }^{8}$ Kevin F. White, The First Sexual Revolution: The Emergence of Male Heterosexuality in Modern America (New York: NYU Press, 1992). 7

9 "Missouri Girl Outraged by a Tramp" Oregonian March 14, 1890

10 "Outrage of a Tramp" Oregonian May 11, 1890

11 "Brutal Work of a Tramp" Oregonian May 28, 1890

12 "Hobo Chased, But Escapes" Oregonian November 19, 1908. 6
} 
Another story, published in 1896, detailed the attack of a woman in Washington. "About 8 o'clock this evening Mrs. Mires, the wife of a well known attorney, was attacked almost at her back door and choked into insensibility."13 Most of these reports share common traits. The supposed hobo entered into the home, invited or uninvited, and attacked women indiscriminately and with sensational violence. Also, in the majority of these reports, an angry mob chased the man accused, if he could be located, and threatened him with acts of brutality. Mob violence was indirectly condoned in these instances, allowing for men of a high class to tap into their own version of primitive masculinity in retaliation for a threatened home. These articles were a complex renegotiation of manhood and sexuality, a warning against uncontrolled urges, and also a means of underscoring the threat of the unattached male on domestic life.

The hobo was a violent threat to the ideals of domesticity, as seen in stories of rape and violence, or, to men embracing an identity of passionate manhood, an escape from the feminizing aspects of home and hearth. In the late 1800 's, Americans began to use the word "overcivilized" to describe men, suggesting a real shift in mindset right before the turn of the century. ${ }^{14}$ Physician George M. Beard, working in 1880, categorized a new disease affecting "over civilized" American men, which he called neurasthenia. The symptoms were,

Desire for stimulants and narcotics ... fear of responsibility, of open places of closed places, fear of society, fear of being alone, fear of fears, fear of

\footnotetext{
13 "Woman Choked by a Hobo" Oregonian October 2, 1896. 1

${ }^{14}$ Rotundo, American Manhood. 251
} 
contamination, fear of everything, deficient mental control, lack of decision in trifling matters, and hopelessness. ${ }^{15}$

This ailment occurred, Beard believed, because the focus had moved from physical exertion to mental exertion, which left men "small and feeble." Doctors feared that neurasthenia would prevent American men from procreating, which would mean the end of the white race. ${ }^{16}$

Rotundo argues that men battled the feminizing aspects of modernity by embracing a second boyhood, one that relied on the homosocial world of play, impulse, and recklessness. Competitive sporting, men's clubs, and an emphasis on physical fitness all tapped into identities earlier associated with youth, but now embraced by men well into adulthood. An acceptance and glorification of the hobo class fell into this re-appropriation of boyhood. Teddy Roosevelt's famed journey West and transformation from a feeble boy to a robust man had already tied the Western experience to physical strength, which resulted in an interest among men in the Western experience, directly through migration, or indirectly through articles and dime novels. The hobo, a problematic figure for Westerners, was a re-creation of a boyhood mentality combined with a rugged Western narrative, something that would gain widespread appeal in the twentieth century.

\footnotetext{
${ }^{16}$ Louis S. Warren, Buffalo Bill's America: William Cody and the Wild West Show, First Edition (Knopf, 2005). 212-213
} 
Society and transient males defined hobo enclaves as realms that were completely absent of "manners, morals, and domesticity." ${ }^{17}$ The desire to be free of the confining femininity of women was one reason men flocked to the open road, where they surrounded themselves with a lifestyle of coarse behavior and lack of attachment. ${ }^{18}$ Rather than reaching the endpoint for masculine identity in marriage, children, and a life at home, the transient male operated in a world in which the civilizing aspects of a feminine presence were completely absent. Taking to the road and working as a migrant laborer in a world surrounded by other men created a path to subvert adulthood and retain the independence of youth. ${ }^{19}$

In actuality, the hobo experience was not devoid of a feminine influence; women had contact with transient males in charitable or sex industry positions. In addition, there was a tendency to create a masculine and feminine gender dynamic within single sex cultures. Susan Johnson discussed this phenomenon in relation to nineteenth century Californian goldmine camps, where certain subsets of a male-dominated society were feminized as a means of re-creating normalcy, and a similar situation was said to have occurred in areas in which itinerant laborers congregated. ${ }^{20}$

Peter Boag discusses relationships in the Portland area among migrant laborers who recreate a gender binary, in which one male takes on the role of a woman. ${ }^{21}$ While largely homosocial, these male bonds could also lead to the formation of sexual

\footnotetext{
${ }^{17}$ DePastino, Citizen Hobo. 83

18 Ibid. 2164

${ }^{19}$ Ibid. 2168

20 Susan Lee Johnson, Roaring Camp: The Social World of the California Gold Rush, 1st edition (New York: W. W. Norton \& Company, 2000).

${ }^{21}$ Boag, Same-Sex Affairs.
} 
relationships. ${ }^{22}$ Josiah Flynt Willard believed that, in 1890 , one in ten transient males were involved in homosexual relationships. ${ }^{23}$ The sexual relationships most frequently linked to hobos were jocker-punk pairings, in which a younger transient male (punk) would grant sexual favors to an older man (jocker) in exchange for protection or camaraderie. $^{24}$ These relationships were of keen interest to sociologists and the public at large due, in part, to the salaciousness of the relationships, and also as proof of the deviance of hobos as a whole. In describing these relationships, Nels Anderson wrote of "attachments, between men and between men and boys that surpass the love of woman ... Many of these are not more than a few days' duration but while they last they are very intense and sentimental." ${ }^{25}$ According to Anderson, punks, while in a position of sexual subservience, were not the lowest in the hobo hierarchy, those who frequented missions or welfare agencies were considered less masculine. Whether this was Anderson's own bias toward charity for able-bodied males or an actual dynamic among transients is unclear. However, according to Anderson, dependency on a hobo for protection through sexual submission was less problematic than having to beg, or receive aid, from one outside of the transient male ecosystem. ${ }^{26}$ of course, Portland elites would disagree, holding homosexual behavior as one of the many degenerate qualities of the transient male that necessitated their removal.

\footnotetext{
22 DePastino, Citizen Hobo. 2198

${ }^{23}$ Boag, Re-Dressing America's Frontier Past.

${ }^{24}$ Boag, Same-Sex Affairs. 128

${ }^{25}$ DePastino, Citizen Hobo. 87

${ }^{26}$ Ibid. 89
} 
If issues of masculinity were at the forefront of the hobo discussion, where did that leave the, admittedly rare, female tramp? Contemporary literature suggests that a truly feminine hobo did not exist, as any woman would have to construct a masculine identity to survive in a realm that was so outside of her own domain. Cliff Maxwell, writing for Scribner's magazine said, "Show me a lady hobo and l'll show you an angular bodied, flint eyed, masculine travesty upon her sex. ${ }^{27}$ Female tramps were a rare, but fascinating phenomenon, especially in discussions of fluid sexuality and gender identity. Women who wished to compete in this domain dressed and acted as men, at least to some extent, and the fact that the sex of a migrant laborer was ambiguous was common newspaper fodder as it so perfectly tapped into existing concerns over the newly changing roles of men and women in the United States.

Peter Boag argues that cross-dressing women, much like the hobo character, were linked to "sexual inversion - depravity, decadence, and degeneration - the very thing America's frontier past promised the nation it was not." To counteract this issue, the cross dressing woman took on redemption roles in dime novels, by returning to their "natural" state, or being reborn through a virtuous act. ${ }^{28}$ In some ways the same sex relationships of transient male populations was similarly condemned and celebrated. Homosexual acts were universally unacceptable to white middle class America, however close bonds between men, especially in mutual acts of physicality, such as hard labor or sporting, became an important tenet of the Western spirit.

\footnotetext{
${ }^{27}$ Cresswell, The Tramp in America. 1880

${ }^{28}$ Boag, Re-Dressing America's Frontier Past.
} 
Masculinity at the turn of the century was in a state of flux. One academic addressing a crowd of transient males in 1914 said, "even the black chattel slave had a chance to propagate his race. You men don't know what it is to have a home, a wife, a child, and yet you think you live." ${ }^{29}$ According to this speaker, manhood required a home and family, something impossible for a migrant laborer to replicate. At the same time, middle class men who lived this idealized home life looked for solace, not in their families, or their work, but in the company of other men, attempting to replicate the freedom and camaraderie of youth. It was in this middle space, between two masculine identities, that ideas of the hobo were constructed.

\section{Man becomes Stereotype: Popular Culture Imagines the Hobo}

The press and popular culture manipulated troubling aspects of the hobo to better conform to existing Western mythology in a variety of ways. Sociologist Jacob Riis created early images of the hobo under the guise of academic study. The earliest example is a photograph titled "The Tramp in Mulberry Street Yard," which was taken in $1887 .^{30}$ The full body image was accompanied by Riis's commentary, which placed the blame for the subject's poverty on the subject himself. ${ }^{31}$ This interpretation echoed charitable and social understandings of poverty and created an image that was easy to use in legislating against transient male.

\footnotetext{
${ }^{29}$ DePastino, Citizen Hobo. 112

${ }^{30}$ Cresswell, The Tramp in America. 3237

31 Ibid. 3359
} 
Images of the hobo created solely for the purpose of entertainment were equally constructed. Sometimes derogatory, sometimes surprisingly kind, these depictions were the beginning of the separation between the hobo persona, which was featured in jokes, stories, and cartoons, and the transient laborer himself, occupying the North End district. The majority of the jokes featured in the Oregonian related to a hobo's unwillingness to work and his avoidance of work through a clever manipulation of those he comes in contact with. These jokes were a means of re-drawing the hobo, removing complex issues of labor, poverty, and violence with the more inoffensive image of a merry trickster who was lazy but generally harmless.

One such joke appeared in 1905, reprinted from the Chicago News:

'Do you believe in the teachings of the Scriptures?' Asked the good woman, as she handed the tramp a generous slice of home-grown pie, 'Yes ma'am,' answered the hobo, 'all but dat part about a feller earnin' his bread by de sweat of his brow. ${ }^{32}$

Following the conventions of the "clever tramp" joke, the following appeared in the Oregonian on January 1, 1890:

Tramp - 'Please, can you give a poor man a little something to eat? But I don't want no bread please.'

Woman - 'You don't want no bread, eh? I guess you aren't starving. You can just get along out of here.'

'Wait till I explain, madam. You see the woman next door just now give me a piece of paving-stone for bread, and as she said she was the best bread maker on this street-'

'The best bread maker on this street! Just you come right in here, my poor man, and I'll show you what good bread really is. Lord, how some people does brag! $!^{33}$

\footnotetext{
32 Oregonian. April 251905 page 8

33 "A Tramp's Diplomacy" Oregonian. February 1, 1890
} 
These jokes had very little to do with the actual problems of the transient male within the city of Portland. They were unlikely to mention outright violence, unless it was comic violence between two men, and issues of vice or depravity were only occasionally touched on, usually in the context of alcohol. More often, the crux of the joke was a clever hobo attempting to outsmart a dim housewife, and usually succeeding. These could be read as a veiled attempt to assert robust masculinity over the confines of a domestic, feminine construct, but also they were amusing yarns capitalizing on the supposed trickery associated with the tramping classes. These depictions of the tramp, unlike news accounts regarding the tramp menace, lack any undercurrent of threat or danger, even when these men stand on the doorstep of one's home.

The goal of this type of comic portrayal, early twentieth century philosopher Henri Bergson argues, is "a laughter aimed at correction and humiliation." ${ }^{34}$ In other words, by minimizing and mocking the tramp character, the man re-enters the fold of society and simultaneously becomes aware that he does not fit. Creating an easily digestible tramp image, without issues of labor, economics, and violence that were so inevitably tied to the experience of itinerant labor, the general public was able to control, correct, and understand the hobo. ${ }^{35}$

Comic depictions of the hobo were not limited to jokes, but also extended to supposedly real news items. In Portland, stories of the clown-tramp were common in Oregonian articles, running alongside stories of rock piles and murder. One such story,

\footnotetext{
${ }^{34}$ Cresswell, The Tramp in America. 2620

${ }^{35}$ Ibid. 2628
} 
appearing in 1898 , recounts a tale of a clever tramp, who, brought into the municipal court, said that he was not a vagrant at all, as he had a profession in instant photography. When questioned further, he produced a piece of glass covered in a white film, and instructed the attorney present to blow on the glass to reveal an instant image of himself.

The preparation of the glass was made to disappear when coming in contact with warm, moist air, leaving exposed an excellent bust of a donkey. When the attorney beheld this he was dumbfounded. No one was standing near enough to see, but from the smiles of the hobo it was evident something had happened. ${ }^{36}$

The tramp in these stories was often the trickster, fooling those in the upper strata of society. An Oregonian story in 1904, potentially true but also reeking of satire, told the story of a trickster tramp named Jack Henry, who "is an exponent of the theory that any kind of physical exertion tends to lessen the lease of life by destroying lifegiving tissue." The article goes on to describe Henry being dragged into the police station because he refused to walk and speaking softly because he refused to use energy to fill his lungs. The judge "said he hated mightily to interfere with Henry's theories, but that he thought 40 days on the rock pile might probably infuse some fresh blood into the fellow's veins, and some more useful ideas into his brain." ${ }^{37}$ A similar story appeared in 1909. In this instance, a tramp broke into a lodging house and stole the clothing of men living there, combining clothes from multiple individuals to create the most luxurious, if ill-fitting, outfit possible. When caught, he claimed only that he

\footnotetext{
36 "Davis Saw the Photo - But he isn't Telling the Story Around" Oregonian April 4, 1898. 10

37 Oregonian "Stories and Romance Gone Astray" Stories of a Day's Doings in the Police Court" July 3, 1904 page 8
} 
had once been clothed in fine attire and missed those days. The amusement of the story relies on the seeming absurdity of a tramp dressed in such finery, which he was still wearing when he was put in jail. ${ }^{38}$

Another popular trope was the hobo storyteller, which was simply a lighter shade of treachery. The tramp at the backdoor, while filled with sexualized implications, was also the theater of the tramp tale, the spun yarn that was designed to gain food, shelter, or money. These tramp stories often appeared in the Oregonian for the amusement of the masses. One such tale, published in 1890, was purportedly told by an albino tramp, a young man who had come from Missoula. When he entered a bar, the bartender asked innocently what caused the hobo's hair to turn white. Plied with drinks, the tramp happily told the story of a trip he had taken in which the train stopped on a bridge, unknown to him, and he watched another tramp jump from the car in order to get a drink, thinking he was on solid ground, and plunging hundreds of feet to his death. The article ends with the revelation, by a Portland man, of the tramp's lie.

'He worked that whisky bunco scheme in 'Frisco until he wore it out.' Said a Portland man who was in the crowd. 'Then he worked Portland. He used to do the silver-haired Albino act in the museum and is one of the smoothest liars west of the Rockies. But it is worth the price of a drink to hear him talk. ${ }^{39}$

In addition to jokes and news stories depicting the lighter side of the unemployed male population, citizens of Portland would also ingest the hobo image at the theatre. Perhaps because vaudeville came into being alongside the beginning of the tramp scare, it was a common field by which the hobo identity was created and

\footnotetext{
38 Oregonian March 121909 "Like Moving-Picture Plot" page 1

39 "Value of Politeness" Oregonian January 26, 1890. 3
} 
exploited for audience entertainment. ${ }^{40}$ Vaudeville was, at its inception, a rowdy and masculine source of entertainment, one that would originally be found in a North End theatre rather than the more elite business district. This distinction changed in the twentieth century, opening vaudeville audiences up to families, which would only serve to spread the hobo mythos farther into American consciousness. Like hobos themselves, vaudeville was a transgressor of boundaries, whether through sex or satire, and the hobo character quickly found a home there.

Tim Cresswell argues that early vaudeville depictions relied on worn tropes such as the hobo refusing to work, bathe, or settle down. ${ }^{41}$ Any hint of sympathy was tempered in the knowledge that the audience was viewing the tramp's antics from a place of superiority and safety. ${ }^{42}$ Historian Lawrence Mintz, in his discussion of minorities on the vaudeville stage, argues that placing a group of people, whether they are recent immigrants, African Americans, or hobos, on the stage, allows "for expression of hostility and superiority." This type of entertainment can either act as a justification of poor treatment directed towards the individual portrayed, or as a safety valve, in which the audience can address their concerns over this population without outward aggression. ${ }^{43}$ In areas in which vaudeville was still operating in a masculine realm of entertainment, the comedy was also rife with sexual innuendo and bodily humor. ${ }^{44}$ This type of entertainment relied on the fact that the hobo, through his appearance and his

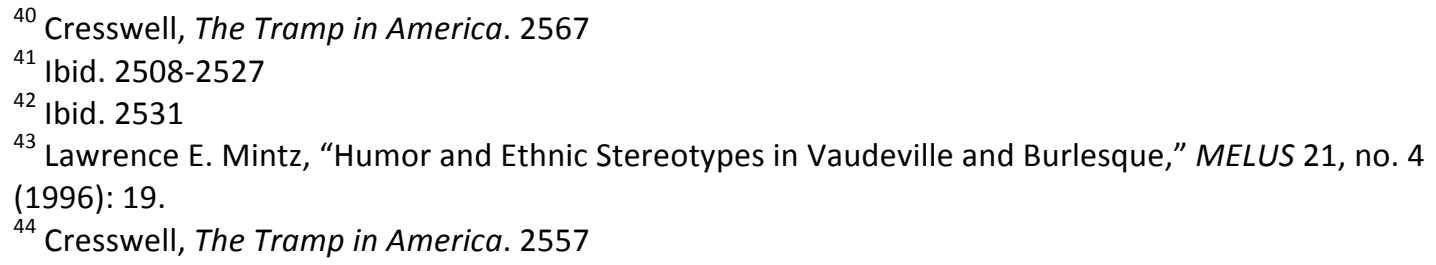


actions, was considered to be obscene, so it was not strange to have this character in tawdry situations. $^{45}$

As the decades progressed, however, the hobo character gained greater depth, as much as could be allowed within the melodramatic stage. He became a clever opponent, a man in disguise, even a hero. Writing in 1904, the Oregonian touches on the appeal of the tramp character as it reviewed a play coming to Cordray's Theater.

The 'tramp' play with the knight of the road as the central figure will always retain a place in the hearts of the masses. The American public are [sympathetic], and they are always ready to listen to the story of the unfortunate, and this peculiar class of ne'er do well nomads amuse and at the same time appeal to them. ${ }^{46}$

'The Convict's Daughter' appeared a few years earlier at Cordray's Theater and capitalized on the trope of a hobo with a heart of gold. The plot revolved around a hobo with "the instincts of a gentleman" travelling through the South to find his daughter. ${ }^{47}$ The play was a huge success, with opening night so packed that, according to one account, the glass in the door was broken due to the crowds. In 1905, "A Jolly American Tramp" played to similarly large audiences; the play was described as "the best delineator of the genus hobo on the American stage. His make-up is perfect. In this play he says some very funny things, and does some very grotesque specialties." ${ }^{48}$ The plot of the play revolved around a tramp with a heart of gold, who was forced to ride the rails, but "who kept his manhood and honesty while living as a hobo." ${ }^{49}$

\footnotetext{
${ }^{45}$ Ibid. 2559

46 "At Cordray's This Week" Oregonian June 19 1904. 18

47 "The Convict's Daughter at Condray's" Oregonian. November 13, 1901. 6

48 "A Jolly Tramp' at the Empire" Oregonian December 8, 1905. 9

49 "A Jolly American Tramp" Oregonian January 14, 1905. 3
} 
Other appearances of the hobo character occurred in "A Thoroughbred Tramp"

which played at the Empire in 1906. According to the Oregonian,

This variety of the celebrated American product is not the disgusting and dirty specimen usually portrayed on the stage, but, while having many of the characteristics, especially the funny ones, naturally attributed to a thoroughbred hobo, yet he is interesting and not at all unpleasant to look upon. ${ }^{50}$

These plays show the transformations of the tramp character away from bawdy entertainment and towards a more sympathetic, if highly dramatized, individual. In addition to vaudeville, many hobo acts came through Portland in the decades starting the twentieth century and played in more family-friendly venues outside of the North End district. In 1899, an entertainment family came to Portland, known as the Wonderful Allens. The youngest member of the family, the Oregonian reports, performed a skit called "Big and Little Tramps" in which she performed hobo songs and dances. ${ }^{51}$ A small girl playing the role of the hobo, especially as early as 1899 , suggests that the process of creating a safe and digestible hobo image began almost as early as the hobo scare itself.

By the first decade of the twentieth century, the hobo as entertainment was well established and often imitated. The hobo, supposedly a menace and a danger, had become so mainstream that, by 1904 , members of the Portland Grand Lodge Elks club chose to dress as them and "ride the rails" to a tramp convention in Baker City. According to the newspaper account, "they were all attired in hobo fashion and looked

50 "The Thoroughbred Tramp" Oregonian. April 26, 1906. 7

51 "The Wonderful Allens" Oregonian January 1, 1899. 15 
the typical 'Weary Willies'." 52 In 1907, a Forth of July costume parade included prizes given for the best dressed hobo and also best dressed "millionaire tramp." Other prizes were given for best Indian costume, best "colored" plantation workers, and best woman voter, all American characters that were regularly parodied. ${ }^{53}$ In 1910 , the Irvington Tennis Club threw a hobo party, encouraging attendees to dress suited to the occasion. ${ }^{54}$ While homeless men still posed a real threat to the city's infrastructure, the middle and upper classes of Portland freely indulged in pantomime.

Historian Louis S. Warren argues, “Americans were drawn to attractions which encouraged them to use their own analytical razors in the separation of truth and fiction." Looking specifically at the instance of the actual Buffalo Bill portraying the fictionalized Buffalo Bill on stage, Warren suggests that the lines between the real and the imagined were purposefully blurred for entertainment during this period.

The social revolutions brought on by city growth and industrialization spawned myriad questions and anxieties... How could one tell good people from bad, honest from crooked, in a bustling, polyglot metropolis, or for that matter in a hustling frontier town, where most people were strangers, everyone claimed to be honest, and seemingly everything was for sale... Entertainments intrigue us by their ability to heighten and then resolve our cultural anxieties. ${ }^{55}$

According to Warren's argument, then, the hobo was not a character that invoked superiority among those in the audience, but rather one who quelled the anxiety and distrust that they might already feel in encountering an "actual" tramp. The storytelling witnessed on the street, as a tramp asked for money or charity, was portrayed and

\footnotetext{
52 "Tramp Elks From La Grande" Oregonian March 16 1904. 3

53 "Offers 50 Prizes" Oregonian June 23, 1907.8

54 “Club Announces 'Hobo' Party" Oregonian March 29 1910. 7

${ }^{55}$ Warren, Buffalo Bill's America.pg 67
} 
deconstructed in the safety of a theatre, addressing and then solving the ambiguities of the itinerant laborer.

This genre was a safe venue by which to encounter the hobo character. He was still operating outside of standard society, but he held no real threat. Images of the trickster, the buffoon, or the hobo with a heart of gold, however, were not without nuance. Issues of gender, charity, and identity lurked beneath the mockery. The idea that a hobo was an honorable man, as in the "Convict's Daughter," threw the treatment of a man based on appearance into question. A hobo able to outsmart a bar full of men or a judge, turned class and intellectual distinctions on their head. It was from these stories that individuals examined their relationship to the hobo in a safe space. From these depictions, a new kind of hobo persona could be formed, one that was not a subversion of the frontier mythos, but a modern embodiment of it.

\section{Frontiersman for a New Era: A Counterculture Icon}

The comic tramp character, a misfit who was occasionally redeemed, was not the only depiction of the transient laborer in popular media. In fact, there was a contradictory story being told, one that imbued the hobo with a rugged Western masculinity, freedom, and strength that was supposedly lacking from the men who lived within a wage labor economy. The resulting narrative became a counterculture cornerstone for the next century, drawing young men to a life on the open road as a battle cry against conformity, American consumerism, or, perhaps, maturity. This 
mythology of adventure and wanderlust sat uneasily beside the image that wealthy Oregonians wished to create.

The idea of striking out on the open road to free oneself goes as far back as the inception of America, and culminated in the mass migrations westward, which were idealized in later generations as moments of immense strength of character and reinvention. Historians like Frederick Jackson Turner immortalized the importance of these early migrants, suggesting that their ability to turn a savage landscape into a civilized society was paramount in the creation of an American identity. In literature, many touched on the Western experience, but the spirit of migration was most eloquently captured in the "Song of the Open Road" by Walt Whitman, published in 1856.

Going where I list, my own master total and absolute, Listening to others, considering well what they say, Pausing, searching, receiving, contemplating, Gently, but with undeniable will, divesting myself of the holds that would hold me. ${ }^{56}$

Whitman, a writer for the wanderer, however, was still troubled by what he saw in the masses of able bodied men roaming the country following the Civil War. To Whitman and his contemporaries, increasing labor unease was an affront to the ideals of free labor that were so hard won in the Civil War. Whitman, in fact, spoke out against these "spectral danger," in the form of migrant laborers, in $1879 .{ }^{57}$

\footnotetext{
${ }^{56}$ Walt Whitman, Leaves of Grass: The Original 1855 Edition, Original 1855 Edition edition (Mineola, N.Y: Dover Publications, 2007).

${ }^{57}$ DePastino, Citizen Hobo. 31
} 
Among the next generation of writers, the tramp menace was separated from the still very tangible horrors of the Civil War. Those coming of age at the turn of the century lacked a defining masculine experience and were therefore subsumed in an urban environment that was dependent on mechanized labor and anonymity. The generation born of this era was acutely aware of the changing identities of the American male and female. ${ }^{58}$ These writers utilized the hobo, not as a caricature, but as an icon for a way of life that was in rapid decay. As Tim Cresswell eloquently said, "the flotsam of modernity - becomes symbolic for the society that is expelling it." ${ }^{59}$

Under the guise of a "new frontiersman," the degenerate hobo became a member of a counterculture movement that embraced those that eschewed the trappings of modern life. One example of this is the story of William Aspinwall, a selfproclaimed hobo who regularly corresponded with John McCook, a professor and chairman of an alms committee in Connecticut. Aspinwall provided a contradictory portrayal of the hobo as a man choosing a fringe lifestyle, rather than simply being acted upon through an unjust economic system or his own personal failings. ${ }^{60}$ Aspinwall described himself as a "Gentleman of the Road . . . from the fraternity of Haut Beaus" in $1893 .{ }^{61}$ He eagerly claimed the role of a philosopher and a gentleman over that of a vagabond. McCook's correspondence with Aspinwall, among other perhaps less colorful

\footnotetext{
${ }^{58}$ Sawyer, "From Whitechapel to Old Town." 27

${ }^{59}$ Cresswell, The Tramp in America. 220

${ }^{60}$ Bruns, Knights of the Road. 62

${ }^{61}$ DePastino, Citizen Hobo. 52
} 
transient laborers, gave him a unique insight into what McCook considered a dangerous, attraction to the road. McCook writes,

When suddenly to one of us comes the discovery that we can stop all this and yet live -nay, grow fat perhaps, and vigorous and strong; drop worry and responsibility... go everywhere, see everything... and when that discovery comes, it is apt to be fatal. ${ }^{62}$

At the forefront of creating this more idealized portrayal of the hobo lifestyle was the transient laborer himself, who developed songs, folklore, complex communities, and political organizations lauding the transient lifestyle. Hobos shared this folklore with those not on the road, and hobo songs and phrases entered into the middle class vernacular by the 1890 's. ${ }^{63}$ By the 1920 s, this new society had a name, hobohemia, and was celebrated by certain subsets of the population nationwide. ${ }^{64}$ Nels Anderson, the father of the sociological study of hobohemia, claimed that the hobo was an extensive reader, a philosopher, a man who willfully ignored social conventions, not through a hereditary deficiency, but through force of will. He argued that these men were not delinquents or dangerous to society, but rather offered an alternative to standard conventions of modern life.

In the hobo enclaves of Chicago's North Side, famous literary and cultural icons such as Carl Sandburg, Edgar Lee Masters, Sherwood Anderson, Vachel Lindsay, Clarence Darrow, Ring Lardner, Emma Goldman, Eugene Debs, Theodore Dreiser, and

\footnotetext{
62 Bruns, Knights of the Road. 74

63 Boag, Re-Dressing America's Frontier Past. 282

${ }^{64}$ DePastino, Citizen Hobo. 58
} 
Big Bill Haywood lectured. ${ }^{65}$ This hobohemian culture was enthusiastically embraced by union organizers, who used this more sympathetic image of the workingman to further their cause, recruit new members into the fold, and also advertise labor issues in hobohemian newspapers such as the Hobo News, distributed by the International Brotherhood Welfare Association. ${ }^{66}$ As the name of the newspaper suggests, even the term hobo became less derogatory in the twentieth century. John Dos Passos, another member of this hobohemian mindset, believed that the rise and decline of the hobo at the turn of the century was the epic of the era. It stretched, he believed, between the eras of Whitman's open road republic and the new era of machinery and an assembly line mentality. ${ }^{67}$ By the 1920 's, Dos Passos and others were willing to place the hobo as a central figure in the American West.

Perhaps the most widespread hobo figure of the turn of the century was Jack London, who rode the rails as a young man and then published stories of his adventures at the turn of the century. By the time London published The Road in 1907, he had already established himself as a proponent of passionate masculinity with the publication of The Call of the Wild in 1903; with an underlying message "that beneath the veneer of all human training lurks a wild animal." ${ }^{68}$ Continuing this theme of the robust man, London wrote that hobo class were "primordial noble men . . . lustfully roving and conquering through sheer superiority and strength." ${ }^{69}$ London's description

\footnotetext{
65 Ibid. 100

66 Ibid. 104

67 lbid. 171

${ }^{68}$ Rotundo, American Manhood. 229

${ }^{69}$ DePastino, Citizen Hobo. 67
} 
is striking for the use of masculine identifiers for a class that had been, in early literary incarnations, universally feminized through their weakness and unwillingness to work. His stories appealed to the hobos themselves, who wished to recover a sullied reputation, as well as middle class men who reexamined what it meant to be a man in an era of ambiguous gender roles at the turn of the century. The hobo mythos became a means of embracing stories of primitivism.

A generation later, historian John Seelye wrote of Jack London and others who lived the hobo life, "like boys at play, they took turns deep-diving into murky water, touching bottom before coming to the surface and gasping for breath. ${ }^{\prime 70}$ Seelye suggested that London, like other writers, created a character that never existed, the noble tramp. London, Seelye suggested, was like a child unwilling to grow, unwilling to submit to conceptions of happiness that society prescribes. Hoboing, then, was not a noble abandonment of consumerism or feminized life, but rather an extended childhood that led to degeneration of the individual. This is the more cynical interpretation of a return to boyhood that historian E. Anthony Rotundo argues was a necessary reinvention of manhood after the dismantling of the self-made man in the late nineteenth century.

By the twentieth century, young men brought up on the stories of Jack London were choosing to live the hobo life in earnest, leaving the comforts of home to jump freight trains. This shift, from reading hobo stories to actually mimicking the hobo lifestyle illustrates how benign hoboing seemed by the early twentieth century. It was,

${ }^{70}$ Seelye, "The American Tramp." 451 
through popular culture references, stripped of danger and made accessible to the masses. In addition, this was perhaps the last remaining avenue available to youth wishing to participate in a Western narrative. Unlike the men they mimicked, they traveled, not for seasonal labor and out of necessity, but rather for adventure. In 1904, three young men were arrested in Albany, Oregon and claimed that they "were on the road for the purpose of experiencing hobo life." ${ }^{71}$ Earlier in the same year, a Portland youth, whose name was given as H. Schelhorn, "of respectable and well-to-do parents" tramped for about a year. The Oregonian notes "The story of his travels and adventures is something wonderful but not calculated to make any one desirous of following in his footsteps." 72

The article then recounts his story in detail; he beat his way to San Francisco, then Arizona and Mexico, heading north briefly on a whaling ship, where members of the crew tattooed him, and then eventually making his way home.

Young Schelhorn is a robust, healthy young man and appears to realize nothing connected with his wanderings except the fun, but to see where this came in is difficult to most others. He may settle down and become a useful man if taken in hand now, but if he gets fairly started in the tattooing business, he may find it necessary to emigrate to Jamaica or some other country a long ways off. ${ }^{73}$

Amateur hoboing was not exclusive to younger generations. In 1910, a story ran in the Oregonian regarding a newspaper editor and "man of means" who assumed the life of a hobo, believing that it would cure him of his ill health. His plan was to ride from

\footnotetext{
71 “Amateur Tramps Sent Home" Oregonian February 1, 1904. 8

72 Ibid.

73 "See the World as a Tramp" Oregonian January 2 1904. 9
} 
Denver to Boston on the rails, living among the hobo class. ${ }^{74}$ And in 1908 , the Oregonian reported that a newlywed couple, Mr. and Mrs. John Barker, decided to have a hobo honeymoon, spending one month riding the rails from Seattle to Lincoln, Nebraska. To carry off this feat, the article explains, Mrs. Barker was required to dress in men's attire. $^{75}$

In June of 1910, an entire page was dedicated to the phenomena of young men leaving home to live as tramps. The article claimed that there were as many as 500,000 tramps in the United States, and three fourths of those were under 21 and tramping for adventure, rather than necessity.

They are but youth, which responds to that spirit within which calls for adventure... They have found a diversion with dangers 10 times as great as cowboying and a hundred times as great as going to war ... For these are the men who yesterday begged for handouts at your back doors. The housewife regarding them as poor, humiliated, unfortunate creatures, asking alms. On the contrary they were the boldest adventurers that the country has ever known.

The article implies that a hobo lifestyle offered an experience akin to war or frontier occupations that were no longer available to the youth of the early twentieth century. Hoboing was considered not merely a facsimile of these experiences, but actually superior. The article detailed the ins and outs of riding trains, focusing on the peril associated with it, giving readers a dose of adventure with a standard tramp narrative. In closing, author William Atherton Du Puy writes,

Altogether it is something of a big, vital thing that these tramps perform. Their school is graduating real men every year. In that delicate, ethical question as to their being a menace to civilization and the dregs of it, there might be another

\footnotetext{
74 "Health Sought as Hobo" Oregonian April 21, 1910. 1

75 “Hobo Wedding Trip" Oregonian September 24, 1908. 6
} 
side. At any rate there are 400,000 of them matriculating these early summer days. $^{76}$

This article suggests that the hobo life was the new rite of passage in the first decade of the twentieth century. This was not the journey westward that had defined previous generations, one that was built on a settlement, home, and family after the tribulations of a long journey, one that Thomas Condon placed at the forefront of the identity of an Oregonian. Rather, the creation of an identity became the journey itself, one that would not be made to secure a home, or money, but exclusively for adventure. Speaking on the transition from boy to man at the turn of the century, E. Anthony Rotundo writes, "a boy struggled to make the transition on his own. There was no rite of passage to help him through. Society left him largely on his own to find his way to an adult identity."77 Riding the rails became a means for some to mark this transition, to assert independence while retaining youthful adventure. How many men took advantage of this opportunity is unknown, but that it stood as an option suggests that the hobo mythology moved from the fringes and became, at least partially, a new Western narrative.

\section{A Reaction Against the Hobo}

Professor of American Literature John D. Seelye, writing in 1963, attempted to explain America's distaste for the "actual" tramp while simultaneously obsessing with the dramatized version. Writing from the standpoint of postwar consumerism and

\footnotetext{
76 "Turning Hobo Merely for Adventure” Oregonian June 19, 1910. 8

${ }^{77}$ Rotundo, American Manhood. 55
} 
success, Seelye suggested that the hobo persona appeals to our Dionysian impulses, but that the actual tramp is "the naked stuff of failure - raw skinned, snaggle-toothed, redeyed, unshaven, dirty, ragged." ${ }^{78}$ He continued,

Part of the appeal of the clown tramp is related to these fears of failure: we may laugh with him because he represented our unconscious desire for uninhibited activity, because he is a tension-breaker, but we laugh at him because we feel superior to his antics. ${ }^{79}$

Seeyle's work stands as one of the few attempts to reconcile the appeal of the tramp and hobo character with the distain for the unemployed laborer during the same period. His harsh portrayal of the actual hobo reflects his distrust of this emerging subculture, one that stood as a challenge to a more homogenous American identity. Roger Bruns, writing in 1980, had a similar theory for the appeal of the hobo.

The figure for which audiences had sympathy was not a recognizable human being but a caricature well divorced from the real world. An audience, even one which harbored fears of, and disgust for the actual thousands of men trudging along the tracks, could feel themselves at a safe distance. ${ }^{80}$

Seelye's interest in the tramp and tramp culture runs parallel to the resurging interest in the hobo through beat culture and, most famously, the works of Jack Kerouac, who traded a boxcar for an automobile, but otherwise mirrored the hobohemian mentality of the 1920's. Seelye's thesis is a potential explanation for the preponderance of hobo literature while the "menace" itself was mistreated and abused on the streets. Seelye argues that it is the abstraction itself, the obvious imitation, which allowed the character of the hobo to exist without the complications of the original.

\footnotetext{
${ }^{78}$ Seelye, "The American Tramp." Pg. 535

79 Ibid. 536

${ }^{80}$ Bruns, Knights of the Road. 102
} 
Seelye's disdain for the glorification of the hobo echoes the frontier booster literature of the turn of the century, in which "true pioneers," those who trod across the Oregon Trail, were true men and women, while those who came later, once trains permeated the landscape, had taken a far easier voyage, lacking in the characterbuilding components of the journey West. The hobo character, while echoing the frontier narrative of travel, lacked the tenacity of the early pioneer class, a weak replication of what had come before him. ${ }^{81}$ However, it was those frontier narratives that may have inadvertently caused such a fascination with the hobo. The "Wild West" had been conquered, but the journey was still alive and well. Perhaps the train was a vehicle of the weakened pioneer, but riding atop the passenger car, or hanging on the break beam was surely a testament to one's masculinity. In other words, the hobo offered the opportunity to recreate the Western experience in a modern context.

Seelye's main contention with the hobo mythology was that it was too freely lumped into the larger frontier narrative, giving the tramp the same gravitas as the pioneer,

Few Americans remain seated for long: the pioneer, the wandering cowboy, the tramp and the Sunday driver are all part of the same pattern. But American restlessness is also evidenced in hard work, productivity, and inventiveness, characteristics shared between the businessmen and the frontiersmen but lacking in the tramp. ${ }^{82}$

In other words, the important component of Turner's Frontier Thesis, and the mythology that it spawned (or was borne of) was not the movement, but the

\footnotetext{
${ }^{81}$ Wrobel, Promised Lands. 129

${ }^{82}$ Seelye, "The American Tramp." 558
} 
settlement. Without settlement, hobos must remain outside of the American identity. Seelye continues "the tramp is a mockery of all that Turner meant by 'coarseness and strength combined with acuteness and inquisitiveness." ${ }^{83}$ Seelye was unwilling to allow the hobo as part of the Western narrative. Others argue for the hobo's complete inclusion, suggesting that the hobo character was instilled with the adventure of the pioneer, which was the more salient portion of the western mythology for contemporaries.

What occurred with the hobo, and perhaps all of the caricatured men and women who dotted the Western landscape, was that they were simultaneously the embodiment of the American West and a cautionary tale of what the American West meant. Portland boosters at the turn of the century could not place the unemployed homeless man next to the pioneer at the Oregon Historic Society, lauding him as the next frontiersman, without admitting that the American West was not the land of abundance, wealth and happiness that it had purported to be. But at the same time, he not only permeated the landscape, but the popular consciousness. The actual man, the one standing in the North End of Portland, waiting for a job, or a drink, or a ride out of town, was a menace. But a fictionalized representation of the hobo, appearing in a dime novel, wind blowing through his hair as he held tight to the front of a speeding locomotive, was something to aspire to, the type of manliness lacking in modern America. The hobo was present as a duality, existing in an uncomfortable parallel

83 lbid. 559 
between the real and the artificial, the hero and the villain, the worthy and the unworthy. 


\section{Conclusion: What can be done with the Floating Men?}

"He is on the line of every railroad, but somehow...there is always a surplus crop of his tribe.... with his face toward the setting sun he renews his toilsome march and finally reaches the Pacific shore. . . Here he finds a population enacting the same scene he has witnessed everywhere. . . Alas, the promised land is a myth."1

- Arthur Vinette, 1885

The hobo menace developed into a tangible antithesis to a Frontier ideology that shaped the city of Portland. Idle men, unable or unwilling to elevate themselves, threatened not only the tenets of the city of Portland, but also the tenets of the American mythology of the West. In response, Portland treated homeless male populations with contempt, suspicion, and cruelty. Reform movements meant to elevate individuals from poverty systematically excluded itinerant males, and laws criminalized their existence. At the same time, the hobo mythology emerged as a counter narrative to the Western experience, imbuing these men with masculine traits that were valued in the twentieth century in ways they were not in earlier decades. Slowly, the men that were reviled on the streets became revered in the theatres. Unfortunately this newfound adoration had no immediate impact on the treatment of unemployed laborers. Portland's policies regarding homeless men lasted well into the twentieth century, and continue even today.

Nels Anderson argued in 1925 that World War I put an end to the hobo. The United States began to challenge labor organizations and, by proxy, the hobo mythology, but more importantly, changes in the way the United States utilized labor made the hobo irrelevant. Peter Boag suggests that the mechanization of the 1920's and

${ }^{1}$ DePastino, Citizen Hobo. 64 
30 's changed to role of the unskilled laborer in the American West and therefore destroyed the hobo culture, as it was understood in previous decades. ${ }^{2}$ Other historians have argued that it was the permeation of women into the West at the turn of the twentieth century, replacing men in areas that had once been majority-male, which destroyed the hobo mentality through domestication. ${ }^{3}$ It could also be argued that the Great Depression-in which families, rather than single men, travelled west as laborers-destroyed the homosocial aspects of the migrant labor force that were intrinsic to the hobo persona.

Still others argue that the hobo merely changed vehicles, moving what was once a railroad endeavor into the automobile, but retaining the essence of the tramping lifestyle. ${ }^{4}$ The experiences of those returning from World War I and World War II were similar to those of soldiers following the Civil War; some men lost the will to settle. Instead they preferred to tramp across the country without the trappings of family and community. ${ }^{5}$ Writers continued to follow in the footsteps of Jack London, either by driving across the country in search of meaning in the case of Jack Kerouac, or making the journey metaphorically, connecting to aimlessness if not the economic hardships of the turn of the century through writing, art and social movements.

Whatever the fate of the transient male, it is clear that he did not evacuate the city in 1915. In Portland, the same agencies that served homeless men at the turn of the

\footnotetext{
2 Boag, Re-Dressing America's Frontier Past. 455

${ }^{3}$ DePastino, Citizen Hobo. 176

${ }^{4}$ Ibid. 177

${ }^{5}$ Ibid. 196
} 
century continued to open their doors daily to provide lodging and food for those unable to provide for themselves in the decades to come. The hobo was unfazed by prison terms and rock piles. He changed in name only, moving from hobo, to tramp, to bum. Now he sits on the street as a homeless man, holding a cardboard sign rather than knocking on backdoors. Charities in the city continue to debate giving alms or requiring work. People still worry that handouts will only go to liquor or drugs. Portlanders still grapple with how an idealized version of the city, one now built on progressive politics and stewardship can sit alongside a present and troubling homeless population.

In 2013, according to the Portland Housing Bureau, there were 2,706 homeless men in Multnomah County. The overall homeless population in the county was $61 \%$ male. However, only $42 \%$ of the beds in area shelters were available to men. The rest were earmarked for women or women with children. The majority of shelters available to men required sobriety before services were given. Some facilities also required attendance at church or a few hours of work. Because of these restrictions, half of the homeless men in Portland remain completely unsheltered and do not receive any assistance from the government or philanthropic organizations. While the gap between services available to men and men in need of services has narrowed slightly since 1890 , gender bias is still a very real component of charitable assistance in Portland. ${ }^{6}$

The types of assistance available to homeless populations are strikingly similar to early twentieth century programs. An example of this is Sisters of the Road Café, which

\footnotetext{
6 "2013 Point-in-Time Count of Homelessness in Portland/Multnomah County, Oregon" Kristina Smock Consulting, Portland Housing Bureau. June 2013
} 
provides meals to poor populations. This organization, founded in 1979, uses a hobo symbol, a circle with three x's, as its logo, which means "good food and hospitality." Emblazoned at the top of their website is the tagline, "in here there are no strangers, just friends we've never met," which is reminiscent of the City Board of Charities phrase, "no alms but a friend." The café offers food to patrons in exchange for labor. According to its website, in 2015 one hour of work would earn someone $\$ 6.00$ in meal credits. Assuming that meal credits have a comparable value to the dollar, this falls well below Oregon's current minimum wage, allowing the restaurant to operate without paying a living wage to those working in the facility.

Patrons can also pay for meals with meal tickets. Portlanders unwilling to provide direct alms to those in need can purchase tickets from Sisters of the Road. These cards, in intention, are nearly identical to those provided to Portlanders by the City Board of Charities in 1890, suggesting that Portlanders still doubt whether a person can be trusted with direct assistance. This comparison is not meant to diminish the work of the Sisters of the Road, but rather illustrate that conceptions regarding the homeless created in 1890 are continuously re-enforced by subsequent generations, oftentimes without an examination of the roots of these deeply held prejudices. In essence, the methods of the City Board of Charity are still in use more than a century later.

These prejudices extend beyond charitable organizations and governmental agencies, reaching Portlanders themselves. In February of 2015, the Oregonian wrote a series titled "Our Homeless Crisis," which examined these deep seeded beliefs, most notably the magnet myth, a belief that homeless populations come to the city from 
elsewhere because of the abundance of services available in the city for homeless people. The Oregonian, still rooted in the conservative ideology of its founding, argued that the Portland homeless were perhaps too well taken care of, quoting one homeless man who said "you have to be stupid to starve in Portland." The article blamed Portland's "keep it weird" philosophy for opening the city up to homeless incursions. The solution the Oregonian offered should sound familiar: tough love, fewer charitable resources, and laws to prevent loitering. ${ }^{7}$

Portland's response to the hobo at the turn of the century is a very small portion of a larger story, one in which the American ideal is confronted with contradictions. How those contradictions are handled can create lasting change or, perhaps more often, signal the beginning of crisis. Todd DePastino sums up this transition when he says,

Over these decades, the Hired Man took on many forms - the "tramp" of the Gilded Age, the "hobohemian" of the Progressive Era, the "transient" and "migrant" of the Great Depression, and the skid row "bum" of the postwar period-but each time he appeared at the threshold, he signaled a crisis of home that was always also one of nationhood and citizenship, race and gender. ${ }^{8}$

The challenge that has always faced and will continue to face the city of Portland is to recognize the signal of crisis, something that Portlanders at the turn of the century were largely unwilling to do. The hobo, whether he was a degenerate or a counterculture icon, a criminal or a working class hero, remains an uncomfortable postscript to the frontier mythology, wandering without settling, working without seeing benefit, and

\footnotetext{
7 “Anna Griffin, The 'Magnet Myth"” Oregonian February 15, 2015. http://www.oregonlive.com/portlandhomeless/magnet.html

${ }^{8}$ DePastino, Citizen Hobo. xix
} 
challenging the conception of a shaky Western identity built on industry, fortitude, and success. 


\section{Bibliography}

\section{Books and Articles}

Abbott, Carl. "From Urban Frontier to Metropolitan Region: Oregon's Cities from 1870 to 2008." Oregon Historical Quarterly 110, no. 1 (April 1, 2009): 74-95.

_-_. "Greater Portland: Experiments with Professional Planning, 1905-1925." The Pacific Northwest Quarterly 76, no. 1 (January 1, 1985): 12-21.

- - - Portland in Three Centuries: The Place and the People. Corvallis: Oregon State University Press, 2011.

Basso, Matthew, Laura McCall, and Dee Garceau. Across the Great Divide: Cultures of Manhood in the American West. 1st ed. Routledge, 2001.

Blee, Lisa. "Completing Lewis and Clark's Westward March: Exhibiting a History of Empire at the 1905 Portland World's Fair." Oregon Historical Quarterly 106, no. 2 (July 1, 2005): 232-53.

Boag, Peter. Re-Dressing America's Frontier Past. Kindle Edition. Berkeley: University of California Press, 2011.

- - Same-Sex Affairs: Constructing and Controlling Homosexuality in the Pacific Northwest. 1st ed. University of California Press, 2003.

- - - "Sex \& Politics in Progressive-Era Portland \& Eugene: The 1912 Same-Sex Vice Scandal." Oregon Historical Quarterly 100, no. 2 (July 1, 1999): 158-81.

Bracher, Frederick. "How It Was Then: The Pacific Northwest in the Twenties." Oregon Historical Quarterly 85, no. 2 (July 1, 1984): 154-80.

Bruns, Roger A. Knights of the Road: A Hobo History. New York: Methuen, 1980.

Condon, Thomas. "The Process of Selection in Oregon Pioneer Settlement." The Quarterly of the Oregon Historical Society 1, no. 1 (March 1, 1900): 60-65.

Cresswell, Tim. The Tramp in America. Kindle Edition. Reaktion Books Ltd, 2001.

Cumbler, John T. "The Politics of Charity: Gender and Class in Late 19th Century Charity Policy." Journal of Social History 14, no. 1 (October 1, 1980): 99-111. 
DePastino, Todd. Citizen Hobo: How a Century of Homelessness Shaped America. Chicago: University of Chicago Press, 2003.

Fuller, Tom, and Art Ayre. Oregon at Work: 1859-2009. Portland, Or.: Ooligan Press, 2009.

Gunselman, Cheryl. "IIllumino' for All: Opening the Library Association of Portland to the Public, 1900-1903." Libraries \& Culture 36, no. 3 (July 1, 2001): 432-64.

Harmon, Rick. "Thomas Condon and the 'Natural Selection' of Oregon Pioneers." Oregon Historical Quarterly 99, no. 4 (December 1, 1998): 436-71.

Hedges, James B. "Promotion of Immigration to the Pacific Northwest by the Railroads." The Mississippi Valley Historical Review 15, no. 2 (September 1, 1928): 183-203.

Helquist, Michael. "Portland to the Rescue: The Rose City's Response to the 1906 San Francisco Earthquake and Fire." Oregon Historical Quarterly 108, no. 3 (October 1, 2007): 384-409.

Johnson, Susan Lee, and Johnson. Roaring Camp: The Social World of the California Gold Rush. 1st edition. New York: W. W. Norton \& Company, 2000.

Jordan, Laylon Wayne. "'The Method of Modern Charity': The Associated Charities Society of Charleston, 1888-1920." The South Carolina Historical Magazine 88, no. 1 (January 1, 1987): 34-47.

Kopp, Peter A. "'Hop Fever' in the Willamette Valley: The Local and Global Roots of a Regional Specialty Crop." Oregon Historical Quarterly 112, no. 4 (December 1, 2011): 406-33.

Kusmer, Kenneth L. "The Functions of Organized Charity in the Progressive Era: Chicago as a Case Study." The Journal of American History 60, no. 3 (December 1, 1973): 657-78.

Lansing, Jewel, and Fred Leeson. Multnomah: The Tumultuous Story of Oregon's Most Populous County. Corvallis: Oregon State University Press, 2012.

Laugesen, Amanda, and Amanda Laugeson. "George Himes, F. G. Young, and the Early Years of the Oregon Historical Society." Oregon Historical Quarterly 101, no. 1 (April 1, 2000): 18-39.

Limerick, Patricia Nelson. The Legacy of Conquest: The Unbroken Past of the American West. First Edition. W. W. Norton \& Company, 1987. 
Loy, William G. Atlas of Oregon, 2nd Ed. 2 Revised edition. Eugene, Or: Oregon State University Press, 2001.

MacColl, E. Kimbark. Merchants, Money \& Power : The Portland Establishment, 18431913 / E. Kimbark MacColl with Harry H. Stein. First Edition edition. Georgian Press, 1988.

- - . The Shaping of a City: Business and Politics in Portland, Oregon, 1885-1915. Georgian Press Co, 1976.

MacColl, E. Kimbark, and Harry H. Stein. "The Economic Power of Portland's Early Merchants, 1851-1861." Oregon Historical Quarterly 89, no. 2 (July 1, 1988): 117-56.

Marsh, Tom. To the Promised Land. Oregon State University Press, 2012.

McAfee, Ward M. "The Formation of Prison-Management Philosophy in Oregon, 18431915." Oregon Historical Quarterly 91, no. 3 (October 1, 1990): 258-84.

Mills, Randall V. "Early Electric Interurbans in Oregon: I. Forming the Portland Railway, Light and Power System." Oregon Historical Quarterly 44, no. 1 (March 1, 1943): 82-104.

Mintz, Lawrence E. "Humor and Ethnic Stereotypes in Vaudeville and Burlesque." MELUS 21, no. 4 (1996): 19.

Myers, Gloria. A Municipal Mother: Portland's Lola Greene Baldwin, America's First Policewoman. 1St Edition edition. Corvallis, Or: Oregon State University Press, 1995.

Palmateer, Dmitri. "Charity and the 'Tramp': Itinerancy, Unemployment, and Municipal Government from Coxey to the Unemployed League." Oregon Historical Quarterly 107, no. 2 (July 1, 2006): 228-53.

Park, Robert E. The City. University of Chicago Press, 1925.

Prisco, Salvatore. “John Barrett and Oregon Commercial Expansion 1889-1898." Oregon Historical Quarterly 71, no. 2 (June 1, 1970): 141-60.

Robbins, William G. Landscapes of Promise: The Oregon Story, 1800-1940. Kindle Edition. University of Washington Press, 2009. 
Rotundo, E. Anthony. American Manhood: Transformations In Masculinity From The Revolution To The Modern Era. Reprint edition. New York: Basic Books, 1994.

Sawyer, Chris D. "From Whitechapel to Old Town: The Life and Death of the Skid Row District, Portland, Oregon," 1985.

Schwantes, Carlos A. "Images of the Wageworkers' Frontier." Montana: The Magazine of Western History 38, no. 4 (October 1, 1988): 38-49.

Scott, H.W. "The Era of Progress." The Oregonian, January 1, 1891.

Seelye, John D. "The American Tramp: A Version of the Picaresque." American Quarterly 15, no. 4 (December 1, 1963): 535-53.

Smith, Henry Nash. Virgin Land: The American West as Symbol and Myth. New Ed edition. Cambridge: Harvard University Press, 2007.

Stanley, Amy Dru. "Beggars Can't Be Choosers: Compulsion and Contract in Postbellum America." The Journal of American History 78, no. 4 (March 1, 1992): 1265-93.

Stefano, Christine Di. "Who the Heck Are We? Theoretical Turns against Gender." Frontiers: A Journal of Women Studies 12, no. 2 (January 1, 1991): 86-108.

Sykes, Alan. "Harold Farrow's Splendid Portland, 1910." Oregon Historical Quarterly 99, no. 1 (April 1, 1998): 48-61.

United States. "Bulletin of the Bureau of Labor." Bulletin of the United States Bureau of Labor, 1913 1903, 53 v

Warren, Louis S. Buffalo Bill's America: William Cody and the Wild West Show. First Edition. Knopf, 2005.

Weiss, Robert P. "Private Detective Agencies and Labour Discipline in the United States, 1855-1946." The Historical Journal 29, no. 1 (March 1, 1986): 87-107.

White, Kevin F. The First Sexual Revolution: The Emergence of Male Heterosexuality in Modern America. New York: NYU Press, 1992.

White, Richard. "It's Your Misfortune and None of My Own": A New History of the American West. Reprint. University of Oklahoma Press, 1993.

Whitman, Walt. Leaves of Grass: The Original 1855 Edition. Original 1855 Edition edition. Mineola, N.Y: Dover Publications, 2007. 
Wrobel, David M. Promised Lands: Promotion, Memory, and the Creation of the American West. First edition. Lawrence: University Press of Kansas, 2002.

Wyman, Mark. Hoboes: Bindlestiffs, Fruit Tramps, and the Harvesting of the West. Kindle Edition. Hill and Wang, 2010.

Ziliak, Stephen T. "Self-Reliance before the Welfare State: Evidence from the Charity Organization Movement in the United States." The Journal of Economic History 64, no. 2 (June 1, 2004): 433-61.

\section{Primary Sources - Newspaper}

Scott, H.W. "The Era of Progress." The Oregonian, January 1, 1891.

"Notes and Comment" The Oregonian November 14, 1896, 4.

“Amateur Tramp Goes over Divide" The Oregonian January 22, 1907. 2

"City Board of Charities Annual Meeting Held" The Oregonian. December 20, 1890

"Don't Give to Beggars: Secretary Walpole Says all Worthy Cases Are Taken Care Of" The Oregonian August 5, 1894. 12

"Work for the Worthy: The Deserving Laborers Are to be Given and Opportunity" The Oregonian January 2 1891. 5

"Numerous Applications for Assistance - The Secretary's Suggestion." The Oregonian. July $30,1893.8$

"Systematic Work: How the City Board of Charities Is Conducted" The Oregonian. December 29, 1893. 3

"The Unemployed: Their Ranks Are Beginning to Thin Out." The Oregonian. April 1, 1894. 5

"Helping the Needy" The Oregonian March 3, 1894. 8

"Must Move for Saloon: City Board of Charities Finds New Location." The Oregonian. November 16, 1903

"Idle's Problem is Heard." The Oregonian, February 7, 1915. 9 
"City Board of Charities - Laborers and Poor People Flocking into the City." The Oregonian. January 9, 1892.

"What! I Saw Wood? - A Caller at the City Board of Charities Flies Into a Furious Rage When Offered Work" The Oregonian. July 23, 1889. 8

"City Board of Charities Annual Meeting Held." The Oregonian. December 20, 1890

"Information Wanted: Board of Charities Wishes to know of all cases of Destitution." The Oregonian January 27, 1893. 4

"Chief Parrish's Report." The Oregonian January 6 1890. 5

No title. The Oregonian. May 28 1891. 10

"Two Kinds of Begging." The Oregonian. August 18, 1894. 5

"Court Notes" The Oregonian. February 15, 1986. 10

"In The Municipal Court" The Oregonian. October 21 1896. 6

"Genuine Weary Willie" The Oregonian. October 25, 1901 page 8

"Give Me a Small Hammer, He Says" The Oregonian January 3, 1902.7

“In the City's Trouble Shop." The Oregonian September 7, 1904. 14

“Back to Jail, Then To Work." The Oregonian. August 13, 1905. 36

"Orders Vagrants to Leave Town." The Oregonian. January 6, 1906. 12

"Are Fashions in Crime? William A. Pinkerton Talks of Detective Business." The Oregonian November 5, 1903. 5

"Sticks to His First Story" The Oregonian July 22, 1899. 12

"The Hose Will Come in Handy" The Oregonian April 4, 1890. 5

"Moore Asks for New City Jail" The Oregonian May 30, 1908. 16

"Appealed From the Kangaroo Court" The Oregonian December 24, 1891. 5

"Hard Work for Hobos" The Oregonian November 11 1895. 5 
"Vagabonds Must Labor" The Oregonian December 3 1895. 5

"No Loafing in Jail" The Oregonian December 31, 1896. 8

"Rock Pile Flourishing" The Oregonian November 28, 1897. 5

“No Rockpile for Hobos" The Oregonian December 3, 1901. 10

"Hobos Will Break Rock" The Oregonian December 28, 1901. 7

"City Rockpile is Needed" The Oregonian December 1, 1904. 14

"Hot Day on the Rock Pile" The Oregonian August 1, 1907. 10

"Visit Kelly Butte" The Oregonian October 31, 1906. 13

“Discuss City Rockpile” The Oregonian February 16, 1906. 10

"Hot Day on the Rock Pile" The Oregonian August 1, 1907. 10

"Hard After Hobos" The Oregonian November 1, 1897. 5

"Meet in Annual Session - Prisoners' Aid Society" The Oregonian November 3, 1907. 10

"Deal with Hobos" The Oregonian January 3, 1908. 11.

“Missouri Girl Outraged by a Tramp” The Oregonian March 14, 1890

“Outrage of a Tramp" The Oregonian May 11, 1890

“Brutal Work of a Tramp" The Oregonian May 28, 1890

"Hobo Chased, But Escapes" The Oregonian November 19, 1908. 6

"Woman Choked by a Hobo" The Oregonian October 2, 1896. 1

No Title. The Oregonian. April 25 1905. 8

"A Tramp's Diplomacy" The Oregonian. February 1, 1890

"Davis Saw the Photo - But he isn't Telling the Story Around" The Oregonian April 4, 1898. 10 
"Stories and Romance Gone Astray" Stories of a Day's Doings in the Police Court" The Oregonian July 3, 1904. 8

"Like Moving-Picture Plot" The Oregonian March 12 1909. 1

"Value of Politeness" The Oregonian January 26, 1890. 3

“At Cordray's This Week" The Oregonian June 19 1904. 18

"The Convict's Daughter at Condray's" The Oregonian. November 13, 1901. 6

"A Jolly Tramp' at the Empire" The Oregonian December 8, 1905. 9

“A Jolly American Tramp" The Oregonian January 14, 1905. 3

“The Thoroughbred Tramp” The Oregonian. April 26, 1906. 7

“The Wonderful Allens" The Oregonian January 1, 1899. 15

"Tramp Elks From La Grande" The Oregonian March 16 1904. 3

"Offers 50 Prizes" The Oregonian June 23, 1907.8

"Club Announces 'Hobo' Party” The Oregonian March 29 1910. 7

"See the World as a Tramp" The Oregonian January 2 1904. 9

“Health Sought as Hobo" The Oregonian April 21, 1910. 1

"Hobo Wedding Trip" The Oregonian September 24, 1908. 6

"Turning Hobo Merely for Adventure" The Oregonian June 19, 1910.8

"Anna Griffin, The 'Magnet Myth'” The Oregonian February 15, 2015.. http://www.oregonlive.com/portland-homeless/magnet.html

\section{Archive Collections}

Board of Charities/Associated Charities Correspondence 1889-1914, Public Welfare Commission, State of Oregon Archives, Salem, Oregon. 
City Auditor - City Recorder - Council Ordinance - 4549 - An ordinance to define and punish vagrancy. Container B/24274, Record Number AF/47532. City of Portland Archives, Portland, Oregon.

Board of Charities and Correction, Oregon 1892 "For the partial biennial period ending December 31, 1892. 212. Oregon Historic Society, Portland, Oregon.

\section{Websites}

Portland Housing Bureau "2013 Point-in-Time Count of Homelessness in Portland/ Multnomah County, Oregon" Kristina Smock Consulting, June 2013

Sister of the Road, Accessed February 17, 2015. http://sistersoftheroad.org 